San Jose State University

SJSU ScholarWorks

Fall 2017

\title{
Examining the Role of Arts Education Partnerships in Sustaining Arts Programs in California Elementary Schools
}

Marie-Helene Bauguil

San Jose State University

Follow this and additional works at: https://scholarworks.sjsu.edu/etd_dissertations

\section{Recommended Citation}

Bauguil, Marie-Helene, "Examining the Role of Arts Education Partnerships in Sustaining Arts Programs in California Elementary Schools" (2017). Dissertations. 11.

DOI: https://doi.org/10.31979/etd.8vr8-4rd4

https://scholarworks.sjsu.edu/etd_dissertations/11

This Dissertation is brought to you for free and open access by the Master's Theses and Graduate Research at SJSU ScholarWorks. It has been accepted for inclusion in Dissertations by an authorized administrator of SJSU ScholarWorks. For more information, please contact scholarworks@sjsu.edu. 
EXAMINING THE ROLE OF ARTS EDUCATION PARTNERSHIPS IN SUSTAINING ARTS PROGRAMS IN CALIFORNIA ELEMENTARY SCHOOLS

\author{
A Dissertation \\ Presented to \\ The Faculty of the Educational Doctoral Program in Education Leadership \\ San José State University \\ In Partial Fulfillment \\ of the Requirements for the Degree \\ Doctor of Education \\ by \\ Marie-Hélène Bauguil \\ December 2017
}


(C) 2017

Marie-Hélène Bauguil

ALL RIGHTS RESERVED 
The Designated Thesis Committee Approves the Dissertation Titled

EXAMINING THE ROLE OF ARTS EDCATION PARTNERSHIPS IN SUSTAINING ARTS PROGRAMS IN CALIFORNIA ELEMENTARY SCHOOLS

by

Marie-Hélène Bauguil

APPROVED FOR THE EDUCATIONAL DOCTORAL PROGRAM IN EDUCATIONAL LEADERSHIP

SAN JOSÉ STATE UNIVERSITY

DECEMBER 2017

Arnold Danzig, Ph.D. Department of Education

Megan Thiele, Ph.D. Department of Sociology

Diana Abbati, Ed.D. $\quad$ Superintendent

Los Gatos School District 


\title{
ABSTRACT \\ EXAMINING THE ROLE OF ARTS EDUCATION PARTNERSHIPS IN SUSTAINING ARTS PROGRAMS IN CALIFORNIA ELEMENTARY SCHOOLS
}

\author{
by Marie-Hélène Bauguil
}

This study investigated three arts education partnerships in California elementary schools. The research questions that guided the inquiry were exploratory in nature and intended to reveal the day-to-day functioning of these partnerships, the challenges they faced, and the factors that contributed to their success, through the recounted experiences of the various institutional actors involved. The participants $(n=21)$ comprised school principals and teachers, arts organizations administrative staff, and teaching artists.

Qualitative inquiry methods (in-person interviews, classroom observations, and review of relevant documents) were used to analyze the data. The findings showed that the schools' administrators and faculty appreciated the arts residencies, and they reported the programs' positive impact on students. Despite many benefits, the arts partnerships held a small place in the schools' life: the arts programs were considered supplemental to the core curriculum at one school, rather than being fundamental to student learning, and the two other partnerships reached only one grade level (second grade). The study uncovered several ongoing challenges: lack of proper facilities for the residencies, finding the right teacher-teaching artist match, and inconsistencies in the arts programs. The findings also demonstrated that the teacher-teaching artist relationship was key for the programs' success. The study concluded with a discussion of recommendations for practice and future research. 


\section{ACKNOWLEDGEMENTS}

This dissertation is the culmination of a long journey, through which I have grown professionally and personally. Many people have accompanied me along this path and believed in me. I am forever thankful for their support.

My deepest gratitude goes to the College of Education faculty for accepting me into the program, and for trusting me to complete this journey. Thanks, also, to my professors for their help and their dedication to seeing me succeed. I appreciated the diverse opinions and perspectives they presented. There was something to take away from each and every class, and my practice was made better because of this program.

Thank you to my advisors, Dr. Arnold Danzig, Dr. Megan Thiele, and Dr. Diana Abbati, for their continuous support and guidance, their interest in my research topic, and above all, for their kindness and their generosity. Your help was invaluable.

I am thankful for my family and the many accommodations they made so I could pursue my dream. I am deeply grateful for their understanding and for not complaining when I said "no" to most of things they asked of me in the last three years. To my husband, Alain, thank you for your patience and for the space you gave me so I could spend long blocks of time to write. To my younger son, Clément, thank you for encouraging me and for cheering me on. To my older son, Guilhem, also a Ph.D. candidate, thank you for the many phone conversations we had about our doctoral studies, sharing our doubts and hopes, and encouraging one other. Going through this experience with you was extraordinary. 
Last, this document would not have been possible without the help of my amazing editor, Krista Meade. Thank you very much for revising and proofreading countless drafts and in the process, for showing a genuine interest in my topic. You supported me not only with your editing skills but you became a friend who helped me be calm and remain focused on my goal. You never doubted me. 


\section{TABLE OF CONTENTS}

List of Tables................................................................ xi

List of Figures........................................................... xii

List of Abbreviations........................................................ xiii

Chapter 1. Introduction........................................................

Introduction: The Power of the Arts........................................ 1

Statement of the Problem................................................. 4

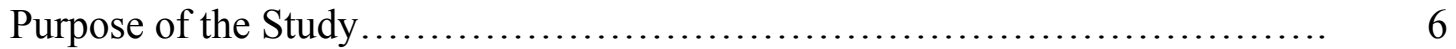

Definition of Terms.................................................... 8

Significance of the Study .............................................. 9

Summary of Chapter................................................. 10

Chapter 2. Literature Review..................................................... 12

Introduction.......................................................... 12

Historical Context: A Brief History of Arts Education (1950-Today)................. 12

Past federal education policies...................................... 12

Implementation of current federal and state policies...................... 15

Challenges for schools that serve low-income students................. 15

Accountability................................................ 16

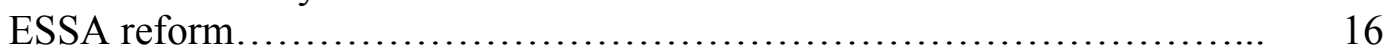

National Core Arts Standards....................................... 17

Arts Education in California............................................. 17

Current California arts policies..................................... 21

Why Arts Education? ............................................... 23

Studio habits of mind...................................................... 25

The arts and Common Core......................................... 26

Arts education may reduce the achievement gap........................ 28

Arts integration................................................. $\quad 30$

Arts Education Partnerships........................................... 31

Models of arts partnerships........................................ 32

Characteristics of effective partnerships............................... 33

Quality in arts education.......................................... 34

Summary of Chapter................................................. 36

Chapter 3. Methods......................................................... 37

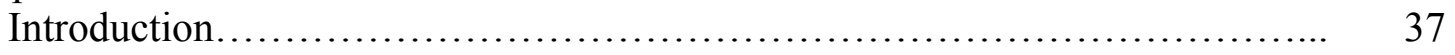

Restatement of Problem................................................. 37

Research Design .................................................... 39

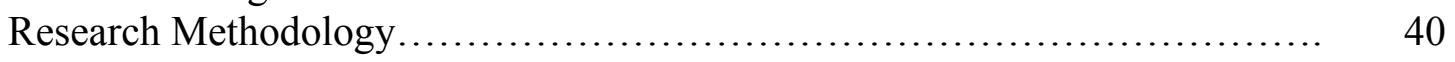

Sampling strategies................................................... 40 
Research sites.................................................. 41

Research participants............................................ 43

Data Collection Procedures............................................... 44

Observations.......................................................... 45

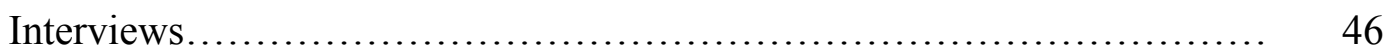

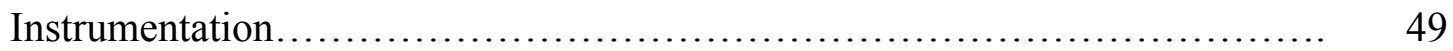

Interview protocol.................................................. 49

Observation protocol............................................. 49

Field notes...................................................... 50

Review of documents.................................................... 50

Data Analysis Strategies.............................................. 51

Establishing Trustworthiness............................................ 52

Construct validity.................................................... 52

Limitations (internal validity) ..................................... 53

Self-disclosures................................................ 55

Delimitations (external validity)........................................ 56

Summary of Chapter.................................................... 57

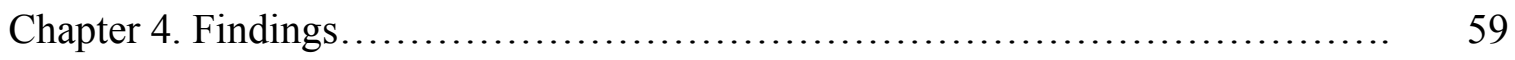

Introduction.......................................................... 59

Descriptive Information on the Participants and the Research Sites

(Research Question 1) .................................................. 59

Description of participants......................................... 59

Overview of the arts organizations..................................... 62

Comparison of the during-school hours arts residency models............ 63

Overview of the school sites and arts partnerships........................ 66

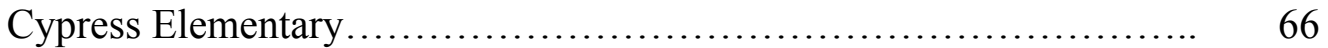

Orchard Elementary ............................................... 69

Shadow Brook Elementary ....................................... $\quad 70$

Description of the school campuses and arts spaces...................... $\quad 72$

Participants Discuss their Experiences with the Arts Partnerships (Research Question 1 Continued)................................................ 77

Appreciation for the partnerships..................................... 77

Appreciation: Arts organizations staff............................... $\quad 79$

Arts instruction was given low priority ............................... 81

Participants Describe Benefits (Research Question 1A) ..................... 82

Positive impact on students............................................ 82

Opportunities to learn from mistakes.............................. 84

Calming effects of the arts..................................... 84

Stand-alone arts instruction: Low impact for classroom teachers............ $\quad 85$

Arts integration: Mixed impact for classroom teachers.................... 87

Participants Describe Burdens and Obstacles (Research Question 1B).......... 89

Challenge: Designated art space..................................... $\quad 89$

Challenge: Hiring visual artists .............................................. 92 
Challenge: Feelings of isolation among the visual artists................ 92

Need for feedback............................................ 95

Challenge: Teachers' participation................................. 96

Shadow Brook Elementary.................................... 96

Classroom management................................... 97

Orchard and Cypress........................................... 98

Classroom management.......................................... 99

Challenge: Schedule.................................................. 99

Visual art schedule at Shadow Brook Elementary.................... 101

Challenge: Continuity within the arts programs...................... 102

Lack of consistency and continuity at Cypress Elementary............. 104

Finding collaboration time at Orchard Elementary................... 106

Participants Describe Strategies to Manage Problems (Research

Question 1C)....................................................... 108

Valley Arts Studio: Setting up new partnerships........................ 108

Funding...................................................... 110

Scheduling challenges that cross the boundaries..................... 110

Facility space................................................. 111

Shadow Brook................................................. 112

Strategy: Hiring experienced teaching artists......................... 113

Strategy: Integrating the arts into the curriculum........................ 114

Strategies at Cypress and Orchard.................................. 115

Strategy: Collaboration.............................................. 118

Collaboration at Cypress.......................................... 119

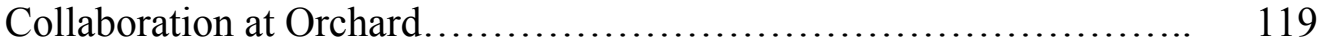

Building relationships......................................... 123

Summary of Chapter.............................................. 125

Chapter 5: Discussion............................................... 129

Introduction..................................................... 129

Summary of the Study................................................ 129

Summary of Findings and Discussion.................................... 131

Participants' experiences of the partnerships........................... 131

Burdens and obstacles............................................ 134

Inadequate facilities for arts programs........................... 138

Artists' feeling of isolation....................................... 138

Consistency and continuity in the programs........................ 139

Teacher-teaching artist relationship.................................. 140

Differing approaches.......................................... 142

Different models of arts instruction.................................. 144

Role of arts partnerships............................................ 147

Recommendations.................................................. 148

Public schools: Engage school and district leaders with the arts........... 148

Public schools: Engage teachers with the arts........................ 149 
Public schools: Designate art space...................................... $\quad 149$

Public schools: Extend the residencies periods............................ 149

Public schools: Set up time for teacher-teaching artist collaboration......... 150

Arts organizations and teaching artists: Articulate visual artists' needs....... 150

Arts organizations and teaching artists: Provide artist training............... 151

Recommendations for colleges and universities......................... 151

Recommendations for policy makers................................. 152

Recommendations for future research.............................. 153

References................................................................ 155

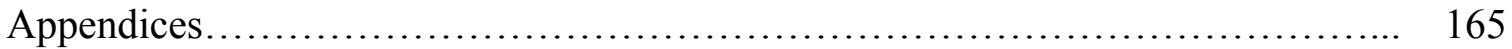

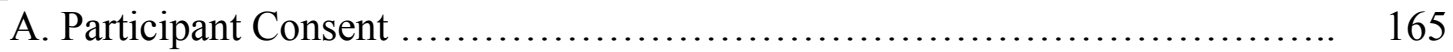

B. Individual Interview Protocol........................................... 169

C. Group Interview Protocol............................................ 174

D. Observation Protocol................................................... 175

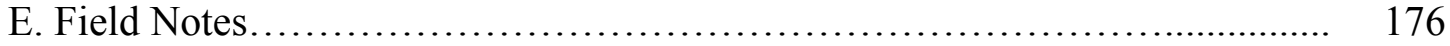

F. Final Coding ....................................................... 183 


\section{LIST OF TABLES}

Table 1. What is Core, What is Common?...................................................... 27

Table 2. Characteristics of Each Art Partnership and Residency Observed...... 42

Table 3. 2015-16 Student Population Characteristics per Site................. 43

Table 4. Participant Characteristics per Institution............................. 44

Table 5. Detail of Observations Across the School Sites....................... 45

Table 6. Interview Characteristics and Number of Interviewees per Site......... 48

Table 7. Summary of Research Methods ................................... 58

Table 8. Participants Characteristics: Positions and Backgrounds.............. 61

Table 9. Visual Arts Schedule Illustrating Diversity of Lessons....................... 71

Table 10. Residency at Orchard: Schedule and Lesson Content................. 122

Table 11. Summary of Findings: Similarities and Differences.................... 126

Table 12. Residency at Orchard: Comparing Preparation and Teaching.............. 136 


\section{LIST OF FIGURES}

Figure 1. The poster project steps ................................. 69

Figure 2. Two examples of Jean's curriculum......................... 72

Figure 3. Detail of the paper collage mural hanging in the school office......... 74

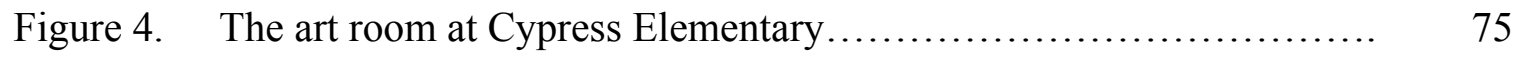

Figure 5. The art room at Orchard Elementary.......................... 76

Figure 6. The art room at Shadow Brook Elementary ..................... 77

Figure 7. Excerpt of teaching artist job description....................... 114

Figure 8. Excerpt of the correspondence between the teachers and the CftA..... 120 


\title{
LIST OF ABBREVIATIONS
}

\author{
AEP- Arts Education Partnership \\ CAC-California Arts Council \\ CAAE- California Alliance for Arts Education \\ CAPE- Chicago Arts Partnerships in Education \\ CCSESA - California County Superintendents Educational Services Association \\ CCSS - Common Core State Standards \\ CCSSO - Council of Chief State School Officers \\ CDE - California Department of Education \\ CETA - Changing Education Through the Arts \\ CfTA - Center for the Arts \\ ELL - English Language Learner \\ ESEA - Elementary and Secondary Education Act \\ ESSA - Every Student Succeeds Act \\ NELS - National Educational Longitudinal Survey \\ NASAA - National Assembly of State Arts Agencies \\ NCES - National Center for Education Statistics \\ NCLB - No Child Left Behind \\ LCFF - Local Control Funding Formula \\ LCAP - Local Control Accountability Plan \\ PTA - Parent teacher Association \\ PE - Physical Education \\ PSESD - Puget Sound Educational Service District \\ SARC - School Accountability Report Card \\ SLDS - Statewide Longitudinal Data Systems \\ STEM - Science, Technology, Engineering, and Mathematics \\ TA - Teaching Artist \\ TAP - Teaching Artist Program \\ VAPA - Visual and Performing Arts \\ VAS -Valley Arts Studio
}




\section{Chapter 1}

\section{Introduction}

To perceive to the fullest what it means to truly love, to care, to understand, to create, to discover, to yearn, or to hope is, by itself, the supreme value of life. Once this becomes clear, it is equally evident that art is the evocation of life in all its completeness, purity, and intensity. To withhold this benefit from human beings is to deprive them indeed.

-Rudolf Arnheim, Thoughts on Art Education

\section{Introduction: The Power of the Arts}

Learning in the arts is essential to a child's education. The arts help children see and experience the world in new ways, better understand themselves, and foster a strong sense of identity. Through the arts, students learn that there are no right or wrong answers, and that all problems can have multiple interpretations; they appreciate unfamiliar cultures and traditions, and develop empathy for people unlike themselves. Intrinsically woven into our lives, the arts are what make us most complete as humans, individually and collectively. They are the "repository of human wisdom" (Fowler, 1996, p. 4), and have the power to span the cultural divides that threaten peace all over the globe.

A complete education is one that teaches not only fact-based knowledge and proficiency in the use of technology, but develops original thinking and self-reflection, promotes curiosity and risk-taking, and enables students to imagine novel solutions to $21^{\text {st }}$ century challenges. Education in the arts nurtures all of these skills and, in the end, encourages the development of a society that is more profoundly alive. Indeed, according 
to Hetland and Winner (2001), an education without the arts is an impoverished education, which leads to an impoverished society.

A growing body of literature highlights the significant benefits of arts education on student outcomes. Students who participated in arts programs fared better academically, emotionally, and socially (Burton, Horowitz \& Abeles, 1999; Duma, 2014; Fiske, 1999; Catterall, Dumais \& Hamden-Thompson, 2012; Heath, Soep \& Roach, 1998; Peppler, Powell, Thompson \& Catterall, 2014) than those who did not. Further, research demonstrated that socially disadvantaged and English Language Learners (ELL) students profited more from involvement in the arts than their wealthier peers (Catterall, 2009). Other studies, which examined the impact of arts integration, a teaching method that uses the arts to teach non-arts subject matter, indicated that infusing arts learning into other content areas reinforced non-arts learning and had an increased impact on overall student achievement (Brouillette, 2012; Pruit, Ingram \& Weiss, 2014).

As an example, Arts Impact is an arts-based professional learning program of the Puget Sound Educational Service District (PSESD) in Washington State. Established in 1999, this program provides schools with artists-in-residency programs and K-8 teachers with professional development in arts integration through one-on-one artist/teacher mentorships. Through a grant from the U.S. Department of Education, PSESD was able to assess the impact of arts-integrated curricula on student achievement. The study was conducted in high-poverty and low-performing schools, located in rural and urban areas over a period of four years, from 2010 to 2014. Seven elementary school sites were selected as treatment schools and seven other schools, with similar demographics, were 
selected as control schools. Performance-based assessments were designed to measure student learning in math and reading through artistic expression, such as creating artwork or performing short choreographed dances, alongside traditional mathematics and literacy assessments. The resulting data, when disaggregated by race, revealed no difference in student achievement scores. Student of color performed as well as their white peers. The same study looked at these students' state test scores in reading and math. The findings showed that while the achievement gap was still evident, it had narrowed significantly (Arts Impact, n.d.).

Despite substantial data that show evidence that arts education has positive outcomes, this knowledge is often overlooked in the broader context of education research and remains largely unknown to educational practitioners. Further, the teaching of the arts is often considered a luxury (Cleary Dale, 2016; Rabkin, 2012) and the expression of an elitist class (Strauss, 2009; Marche, 2015). According to Fowler (1996) and Remer (1996), the primary purpose of American schools today is to serve the country's economic interests and thus, to prepare students for the workforce, rather than educating students to live rich and meaningful lives. As schools struggle with limited budgets and the push for expanding math and science curricula, the arts are seen as "frills" and dispensable, rather than being seen as fundamental parts of learning (Beveridge, 2010; Chapman, 2004; Fowler, 1996). This misconception about the arts causes an increasing number of children to receive little or no exposure to the arts, leading the "public visual and performing arts [to become] an even more exclusive reclusion for a dwindling educated elite" (Remer, 1996, p. 79). 


\section{Statement of the Problem}

Arts programs have gradually disappeared from most public schools in the last two decades, regardless of federal education policies that define the arts as core academic subjects (No Child Left Behind Act of 2001, 2002; Every Student Succeeds Act of 2015, 2015). As a result of the No Child Left Behind (NCLB) and Every Student Succeeds Act (ESSA) policies, schools have narrowed their curricula to focus on the few academic subjects - math, science, reading, and writing - that are evaluated through standardized testing ( $\mathrm{Au}, 2007$; Berliner 2011; Beveridge, 2010). The sustained attention given to test scores, which are considered to be accurate measures of students' academic success, contributes to marginalizing the arts, keeping them peripheral to student learning. Not only has NCLB reduced the instruction time dedicated to arts instruction, it has also limited students' access to these programs. ELL students, particularly, may be denied participation in arts activities in order to be placed in remedial math or reading classes intended to help raise their test scores (Baker, 2012; Beveridge, 2010).

The attitude toward arts education in California follows this national pattern. In 2001, the state enacted strong arts education policies by adopting Visual and Performing Arts (VAPA) Standards in four disciplines: dance, music, theatre and the visual arts. However, it does not mandate that schools follow these standards, leaving the decision of providing arts instruction to the discretion of district and school administrators. A 2007 statewide study, conducted by SRI International, reported that California K-12 public schools were far from reaching the state goals for arts education and revealed inequalities in access to arts programs. According to the study, only $10 \%$ of elementary schools provided 
standard-aligned arts instruction in the four disciplines defined by the VAPA standards (Woodworth et al., 2007). At the elementary level, funding for arts programs was irregular and limited and, in many cases, relied on private sources, creating strong disparities among districts. The most developed arts programs were found in wealthy communities; in high-poverty districts, the delivery of arts instruction was often left to the responsibility and initiative of classroom teachers (Woodworth et al., 2007). When funding was available, many elementary schools opted to partner with community organizations or individual artists in order to provide instruction in the arts. According to a 2008 survey of California school districts, also conducted by SRI International, 68\% of elementary schools that provided arts programs offered these programs through a partnership with a cultural or an arts organization (Woodworth, Petersen, Kim \& Tse, 2009).

The nature of these partnerships varied greatly, providing students with a variety of arts learning experiences, ranging from simple exposure to the arts, such as single events (attending a play or visiting a local artist or museum) to artist-in-residency programs that offered standard-based arts instruction and, in a few cases, arts integrated curricula. Some of these partnerships included professional development opportunities designed to build teacher capacity for teaching the arts. While these partnerships gave students an exposure to the arts schools could not have provided on their own, their scope was nevertheless limited. Typically, the partnerships only offered selected arts disciplines, such as music or theatre, or served only selected grade levels (for example, all $5^{\text {th }}$ grade classes), causing inequalities in access to these programs (Woodworth et al., 2009). 
California public schools are faced with the unprecedented challenge of preparing students for a quickly-evolving and uncertain future, while addressing the specific needs of a growing ELL population. Many educators and policy-makers agree that schools should teach all students to be creative, critical thinkers, skilled in communication and collaboration. The adoption of Common Core State Standards (CCSS), the emphasis on Science, Technology, Engineering, and Mathematics (STEM) education, and the widespread use of technology, are presumed to be the appropriate responses that will turn this ideal into reality. Although reforming the education system has become a necessity, it remains to be seen whether or not these efforts will help students reach their potential. Regardless of the different perspectives on how to foster the skill set that will shape students into imaginative, inventive, and resourceful beings, the arts are essential tools in this endeavor. It is critical to make school administrators and teachers aware that the arts are more than nice and fun activities (Beveridge, 2010; Chapman, 2004; Hoffman Davis, 2008): they develop high-level thinking skills (Eisner, 2002), promote self-discipline and motivation (Jensen, 2001) and reach children that are not ordinarily reached (Fiske, 1999). With this awareness, a culture of change for the arts would emerge.

\section{Purpose of the Study}

This qualitative and descriptive study investigated arts education practices in elementary schools, specifically when arts instruction was provided through a partnership between a school and an arts organization. The intent was to gain a deep understanding of how arts partnerships functioned on a day-to-day basis, to identify the challenges they faced, and the factors that contributed to their success. To that end, the study examined 
and compared three arts partnerships that involved two arts organizations and three elementary schools. Two of the schools had a partnership with an arts organization that focused on arts-integrated learning; the third school partnered with an arts organization that provided direct instruction in the visual and performing arts.

The overarching question that framed this inquiry was: How do the various institutional actors (school and arts organizations administrative staff, classroom teachers, and teaching artists) describe their experiences working within an arts partnership? To better answer this question, three sub-questions were studied:

- What benefits did the various institutional actors listed above derive from the partnership?

- What burdens and obstacles did the participants face when they were involved in the partnership?

- What strategies did they utilize to navigate or manage the issues that arose from the partnership?

Since the primary goal of this study was to create a rich narrative of how arts education partnerships worked, qualitative research methods were the most suited to gather and analyze data. The participants $(n=21)$ included school staff (principals and classroom teachers) and arts organization staff (executive directors, director of education, director of programs, and teaching artists). Primary sources of data consisted of classroom observations, and face-to-face interviews. The data was analyzed from the "ground up," (Yin, 2014, p. 136), allowing for the discovery of emerging patterns, 
concepts, and themes across the study sites. The data were managed with Dedoose software.

\section{Definitions of Terms}

This study uses terms that, depending on the context, may have several meanings. In order to clarify the meaning of these terms for the purpose of the study, and to ensure consistency throughout the document, the following definitions are provided:

- Art education/Arts education: Both terms are used in this study. When "arts" is plural, it indicates the visual arts and performing arts, which include dance, music, visual arts, and theatre disciplines. When the word "art" is used, it refers only to the visual arts.

- Art instruction/Arts instruction: Same distinction as described above.

- Arts for arts' sake: The study of individual arts disciplines, such as dance, music, theatre, visual arts, architecture, and media arts.

- Arts integration: An approach to teaching and learning that uses arts disciplines as tools to teach other subjects. Quality arts integration defines learning goals in both the art form and the non-art content, as described in The Kennedy Center for the Arts' definition of arts integration: "Arts integration is an approach to teaching in which students construct and demonstrate their understanding through an art form. Students engage in a creative process which connects an art form and another subject area and meets evolving objectives in both" (Silverstein \& Lane, 2010).

- Arts infusion: Another term used in this study to refer to arts integration. 
- Arts partnership: A collaborative educational effort between a school (or a school district) and an arts organization to provide children with arts instruction. The duration of this type of partnership is usually short-term, and may be repeated each year. Dreeszen (1992) offers the following definition: "The deliberate cooperation of community cultural organizations, school teachers and administrators, local arts agencies, and public and private funders to connect children with arts experiences and instruction in and out of schools (p. 8).

- Arts organization: This term has many different definitions. In this study, the term refers to an institution that endeavors to bring arts education into schools.

- Artist residency: An arts program that is provided through an arts partnership, and involves a teaching artist being in residence at a school for a short period of time, usually a few weeks out of the school year.

- Teaching artist: An artist who dedicates part or most of his/her professional practice to teaching in schools.

- Visual arts: Arts disciplines that include, but are not limited to, painting, photography, design, sculpture, and architecture.

- Performing arts: Arts disciplines that are performed for an audience, such as dance, music, and theatre.

\section{Significance of the Study}

Arts education partnerships are increasingly becoming key in providing arts programs in elementary schools (Carlisle, 2011; Colley, 2008; Remer, 1996). The forms and longevity of such alliances vary widely. Research shows that, while some partnerships 
grow and prosper over time, many others cease after a few years (Colley, 2008; Remer, 2010). Large-scale arts education partnerships have been widely investigated, particularly with regards to learning outcomes (Bodilly, Augustine \& Zakaras, 2008; Catteral \& Waldorf, 1999; Duma, 2014; Peppler, Powell, Thompson \& Catterall, 2014; Scripp \& Paradis, 2013). Much less is known about smaller partnerships, which involve only one school and an arts organization, and how these partnerships succeed and thrive.

The impact of this study is threefold. First, it brings attention to arts education practices in elementary schools. Second, it adds to the existing literature by providing insight into how schools are able to sustain arts programs when they have many other requirements (e.g. mandated accountability measures, budget constraints) to which they must respond. Third, qualitative research offers rich and complex narratives that explain the "how" and "why" of an issue in meaningful context. This study offers detailed and relevant information for schools with no experience of arts partnerships, giving them greater capacity to ask the right questions in order to build their own arts programs.

\section{Summary of Chapter}

Instruction in the arts is a vital component of a child's education, and has the potential to transform students' learning experiences. Yet, public schools arts programs are in decline as a consequence of NCLB and ESSA policies, which forced schools to narrow their curricula to subjects that are tested. In California elementary schools, funding for arts education is scarce and inconsistent; few schools are capable of offering standardaligned arts instruction in the four disciplines as required by the VAPA standards. Many of the districts and schools that are able to allocate funds to arts programs have 
outsourced the delivery of these programs, through partnerships with local arts organizations. This study investigated arts education partnerships at three elementary schools, in order to deeply understand the conditions under which they operate and the factors that are necessary to their success.

The first chapter provided an introduction to the study. It briefly presented the focus and objectives for the inquiry, its significance, research questions, and research methods. Chapter Two provides a context for the study by examining the literature pertinent to the research questions including: 1) the impact federal and state education policies have on public schools' arts programs; 2) the benefits of arts instruction; and 3) the role arts education partnerships play in maintaining arts programs in elementary schools. Chapter Three details the research design, data collection, and analysis methods used in the study. The analysis and interpretation of the data are presented in Chapter Four. Chapter Five concludes this dissertation; it summarizes and further discusses some of the key findings, and finishes with a discussion of recommendations for practice and future research. 


\section{Chapter 2}

\section{Literature Review}

The arts are not pretty bulletin boards. They are not turkeys and bunny rabbits. They are not frivolous entertainment. Rather, they represent humanity. They are the languages of civilization through which we express our fears, our anxieties, our hungers, our struggles, our hopes. They are systems of meaning that have real and important utility, which is why schools that give students the means and encouragement to explore these realms provide a better education.

—Charles Fowler, Strong Arts, Strong Schools

\section{Introduction}

Chapter Two presents a review of the literature on arts education relevant to the present study. The chapter is divided into three main sections. It begins with an overview of national and California education policies and discusses how these policies have affected the status of arts education in California elementary schools. The next section focuses on arts education outcomes. The chapter concludes by reviewing the existing literature on arts education partnerships and the place they occupy in sustaining the arts in the schools.

\section{Historical Context: A Brief History of Art Education (1950 - Today)}

Past federal education policies. Up until the mid-60s, classroom teachers were responsible for delivering arts education at the elementary level. Since this was a local effort, there was no guarantee that every student would be exposed to the arts. In 1965, President Lyndon Johnson's Great Society Program acknowledged, on a national level, the significance of arts education for the first time in the history of United States. In addition to the Elementary and Secondary Education Act (ESEA, 1965), which 
guaranteed every child in America equal access to education, several arts and humanities endowments were created to provide financial support to state and local arts councils so they could develop and implement arts programs for grades K-12. The National Endowment for the Arts began sponsoring artist residency programs in schools across the country; these laid the foundation for the artists-in-schools programs that are in place today (Remer, 2010).

Due to the various interests and collaborations between the federal government and local arts agencies, many educational practices emerged and created a variety of instructional resources. This system contrasted greatly with the local structure of arts programs in place prior to the ESEA. Specifically, the earlier arts programs, sponsored by local school boards, were essentially curriculum-based instruction designed to enrich students' general education and provide them with basic skills in visual arts and music. (Remer, 2010). After the ESEA reform, the development of art programs depended on partnerships between schools and local art councils, cultural institutions (e.g. museums), and federal agencies. The presence or absence of these partnerships often determined the degree to which arts programs were available in a school district.

Despite inconsistent funding at both the federal and state levels, an increasing number of elementary schools began to include regular arts instruction. In 1994, the Voluntary National Art Standards were adopted, which subsequently triggered the creation of arts standards in forty-seven states. These state standards were only suggested frameworks for local arts policies; there were no specific criteria to which districts and schools were held accountable for the implementation of the standards (Remer, 2010). 
Parallel to these state initiatives, support for arts education continued to grow at the federal level. The Arts Education Partnership (AEP) was established in 1995 with the mission of "advancing the arts in education through research, policy, and practice" (AEP, n.d). AEP is a national network of more than 100 arts organizations, created through combined efforts between the National Endowment for the Arts, the U.S. Department of Education, the Council of Chief State School Officers (CCSSO), and the National Assembly of State Arts Agencies (NASAA).

As a result of strong lobbying by arts education groups, the arts were included in the No Child Left Behind (NCLB) Act of 2001, which was passed into law in 2002, and extended the ESEA reform. NCLB established arts education as a core subject, listing the arts in the definition of core academic subjects as follows: "The term 'core academic subjects' means English, reading or language arts, mathematics, science, foreign languages, civic and government, economics, arts, history, and geography" (AEP, 2004, p. 7). Even though the arts were now considered academic subjects on par with math or reading, the enactment of NCLB still had dire consequence for arts programs. The primary focus of NCLB was to make states accountable for student performance through standardized tests, with an emphasis on math and reading. Schools that did not show annual increases in their students' test scores were penalized through budget reduction. For that reason, schools decreased time and resources devoted to the arts and increased the time to prepare students for testing. Even arts teachers were drafted into the effort, and were required "to help students to improve their 'academic' subject test scores" (Freedman, 2007). 
Implementation of current federal and state policies. A study conducted by the Art Education Partnership reveals that there is a strong consensus across America that arts instruction is fundamental for quality K-12 education, but there are significant variations in how each state enacts its arts education policy (AEP, 2014). The study notes that most states use general terms in their legislation to define "arts," such as "the visual and performing arts" or "the fine arts," but they rarely specifically define which arts disciplines are included in these terms. Although the terms they use can be vague, fortynine states (the exception is Iowa) have now adopted elementary and secondary arts standards (AEP, 2016). Among these, forty-five states — including California—require that elementary schools provide arts instruction, and twenty-seven states - again including California — have defined the arts as core academic subjects (AEP, 2016). Given these facts, it is surprising that millions of students receive no arts education (AEP, 2014). In reality, the number of mandates a state puts in place for arts education does not guarantee that it fully implements those policies. Standardized test preparation has taken time and funding away from arts programs, and has been a serious barrier to successful implementations of arts education policies (AEP, 2014).

Challenges for schools that serve low-income students. In schools that serve lowincome student populations, the difficulties are magnified: a study from the National Center for Education Statistics (NCES) showed that elementary schools with highpoverty populations receive less music instruction than more affluent schools (Parsad \& Spiegelman, 2012). The same was true for visual art classes. These findings were replicated in a California survey conducted by the Los Angeles County organization Arts 
for All in 2011. That study found that students attending Title I schools in Los Angeles had disproportionately low access to arts education compared to their more economically advantaged peers (Waldorf, L. \& Atwill, K., 2011).

Accountability. An additional factor that contributes to the lack of K-12 arts education is that many states do not have accountability systems to determine how well schools are complying with state arts education policies. Thus far, only three states (Minnesota, New Hampshire, and New Jersey) have established large-scale surveys to assess the condition of arts programs in their public schools (AEP, 2014) and seventeen states (excluding California) have policies that require state, district, or school-level assessment of student learning in the arts (AEP, 2016). Further, New Hampshire, along with Florida and Michigan, are experimenting with statewide arts assessments, utilizing a wide range of testing techniques: multiple-choice questions to evaluate arts learning (Florida), and developing project-based evaluations - the students submit art work or perform a piece of music - that are evaluated by teams of art school teachers (New Hampshire and Michigan). (Zubrzycki, 2016).

ESSA reform. Succeeding NCLB reform, the Every Student Succeeds Act (ESSA) was signed into law on December 10, 2015. While ESSA continues to promote the accountability and testing policies established by NCLB, it gives more latitude to the states in defining and implementing their accountability systems (Klein, 2016). In ESSA, the definition of "core academic subjects" is replaced by the term "well-rounded education." The definition of a "well-rounded education" retains the "arts," which includes visual and media arts, dance, and theatre (National Art Education Association 
News, 2016). Further, the new definition broadens the list of subjects, adding writing, technology, engineering, computer science, music, career and technical education, health, and physical education to the NCLB definition of "core academic subjects" (Jones \& Workman, 2016). In the context of the new law, all subjects—including the arts and music — are eligible for Title 1 funds. In addition, the Arts in Education fund, a federal program under NCLB, includes new grant opportunities to support schools partnerships with community-based organizations (National Art Education Association News, 2016).

National Core Arts Standards. The implementation of the Common Core State Standards prompted the need to create new arts standards, aligned with Common Core goals. The National Core Arts Standards, which were adopted in 2014, are the result of three years of collaboration among state and local arts agencies and arts educators. Compared to the 1994 National Arts Standards, the new standards include five arts disciplines (dance, media arts, music, theatre, and visual arts), provides greater structure and content alignment among the arts forms, and includes assessment tools (Poulin, 2014). Since their release in 2014 , fourteen states have adopted revised arts standards and seventeen states (including California) are in the process of revising their arts standards (National Coalition for Core Arts Standards, 2017).

\section{Arts Education in California}

Funding for arts education has been very scarce since the passage of Proposition 13 in 1978, which severely reduced educational funding for local school districts. In addition, the quality and frequency of arts programs is particularly inconsistent due to competing 
priorities and limited funding. Further, these inconsistencies prevail not only across the state; they occur within districts, schools, and even within classrooms.

Since 2001, in accordance with NCLB, the State of California has designated the arts as core subjects and adopted visual and performing arts standards in four disciplines. In 2004, the California State Board of Education added a Visual and Performing Arts (VAPA) framework designed "to help classroom teachers and other educators develop curriculum and instruction in the arts so that all students will meet or exceed the content standards in dance, music, theatre, and the visual arts" (California Department of Education, 2004, p. x-xi). The California Education Code requires elementary schools to provide students with instruction in four art disciplines (California Department of Education (CDE), 2001). The California Education Code (2001), Section 51210 states: “(a)The adopted course of study for grades 1 to 6 , inclusive, shall include instruction, beginning in grade 1 and continuing through grade 6 , in the following areas of study: ... (5) Visual and performing arts, including instruction in the subjects of dance, music, theatre, and visual arts, aimed at the development of aesthetic appreciation and the skills of creative expression." However, the CDE did not establish provisions mandating student assessment in the visual and performing arts. In spite of the presence of meaningful art policies, this is one reason for limited visual art instruction in elementary schools.

In a landmark study in 2007, the Hewlett Foundation commissioned SRI International to conduct an inventory of state and federal policies on arts education, and to assess how these policies affect arts education in California. The study analyzed arts instruction 
practices in grades $\mathrm{K}-12$ and provided reliable information on the practice of arts education in California as compared to the state goals. The results demonstrated that schools were far from reaching these goals: 1) $11 \%$ of elementary and secondary schools provided a standard-aligned curriculum in the four art disciplines; 2) the methods of delivering arts instruction varied by school, often resulting in limited exposure to the arts at the elementary level and limited participation at the secondary level; and, 3) students attending schools in high-poverty neighborhoods had less access to arts instruction than their peers in more affluent communities. Last, the study established that elementary students who had music and visual art programs received less instruction time than their peers across the country: only 32 and 28 hours per year of music and visual arts instruction were provided, respectively, compared with 46 and 44 hours per year nationally (Woodworth et al., 2007).

Other findings, specifically regarding the elementary level, were more striking in the sense that they showed further deviation from state standards. Approximately $90 \%$ of elementary schools did not provide standard-aligned arts instruction across all four disciplines, and only $42 \%$ of those schools offered standard-based visual art instruction. Among the schools that offered visual art instruction, $30 \%$ of elementary schools employed art professionals from local art organizations, and $22 \%$ of elementary schools relied on volunteers. In 2005 , only $14 \%$ of elementary schools that offered visual art instruction relied on a full-time art specialist. Finally, the resources available for visual art instruction were usually lacking: for example, only $13 \%$ of elementary schools had an art room (Woodworth et al, 2007). 
Addressing the issue of funding, the study reported that the primary source of funding came from general district funds, but this was not representative of all grades. At the elementary level, arts programs relied heavily on private funds such as parent-teacher associations (PTAs) and school foundations. This created an inequality in student access to these programs, since wealthy districts were able to raise more money than less wealthy districts. For districts that could not afford to hire arts specialists, elementary arts instruction was left to classroom teachers, who rarely had adequate training, were not familiar with the VPA standards, and were not provided with opportunities to attend artsspecific professional development workshops (Guha, Woodworth, Kim, Malin \& Park, 2008). In 2005 , only about $25 \%$ of teachers participated in arts-related professional development, and $75 \%$ of teachers reported that the lack of professional development was a barrier to providing arts instruction (Guha, et al., 2008).

Since 2013, state-level funding for education has been stable. The passage of Proposition 30 in 2012, which increased the state sales tax by a quarter cent and raised income tax rates on people making more than $\$ 250,000$, guaranteed there would be no cuts in education funding until 2018 (CBS News, November 6, 2012). Also, the state's new funding formula for public schools, the Local Control Funding Formula (LCFF), allocates more money for low-income students and allows greater flexibility in determining how to spend it. Local districts decide how to portion out funds to meet the needs of their students in accordance with state guidelines. This creates an opening for arts education; the districts have the option to choose to include comprehensive art 
programs in their Local Control Accountability Plans, (LCAPs), fund those programs, and implement them.

Current California art policies. There is a growing interest in arts education in California. In the last few years, several initiatives have been created to promote arts education and engage in lobbying efforts at the state level. For example, California's Education Code includes specific standards for dance and theatre, yet the state does not provide teaching credentials for those disciplines. Under the current system, individuals who major in dance as an undergraduate can only teach dance after obtaining a credential in Physical Education, and persons who major in theatre can only teach theatre after receiving an English credential. On January 27, 2016, Senator Ben Allen, Chairman of the California Joint Committee on the Arts, introduced SB 916, the Theatre and Dance Act (TADA), a bill that establishes single-subject teaching credentials for dance and theatre. The bill was passed by the State Assembly on August 18, 2016, and was signed into law by governor Jerry Brown on September 26, 2016.

In another example, California legislators have significantly increased funding for the California Arts Council (CAC), a state agency whose mission is "advancing California through the arts and creativity" (CAC, n.d.). The 2016-2017 state budget allocates $\$ 18.7$ million - with an additional $\$ 6$ million for the Arts in Corrections program - to the CAC. By comparison, the allocations to the agency were $\$ 2$ million in 2013-2014 and \$7 million in 2014-2015 (CAC press release, June 28, 2016).

California is also participating in the Arts Education Data Project, along with three other pilot states-North Carolina, Ohio, and Wisconsin. The aim of this nationwide 
project is to gather data on arts education in secondary schools, and to measure arts program availability and participation according to the policies of each state. The compiled data, derived from the pre-existing data obtained by the Statewide Longitudinal Data Systems (SLDS), will allow measurement of change in students' access and participation in the arts over time, and identification of schools in which students are underserved (State Education Agency Directors of Arts Education, n.d.).

Another sign of increased support for the arts is CREATE CA, a statewide arts education coalition, which includes the California County Superintendents Educational Services Association (CCSESA), the California Alliance for Arts Education (CAAE), the California Department of Education (CDE), the California Arts Council (CAC), and the California State PTA. CREATE CA, established in 2011, was charged with promoting an arts and creative education agenda to "ensure each student reaches his or her full potential by broadening California's educational vision, policy and practices to promote innovation, economic development and creativity" (California Department of Education, 2013, p.12).

The coalition created and released a "Blueprint for Creative Schools" in 2015. The Blueprint has recommendations that touch on every aspect of teaching and learning in all K-12 schools. It stresses the importance of using arts integration as a vehicle to transform pre-school and K-12 education. What makes this effort even more compelling is the commitment to developing a long-term agenda, ensuring sustainability, and creating a program of assessment and accountability. Another significant provision in the Blueprint is the creation of a permanent staff, giving rise to a management structure that enables 
collaboration between all the major organizations. An important function of the staff is to broadly market arts education to the greater public (CREATE CA, 2015). The Blueprint release coincided with the statewide "Creativity at the Core" initiative, which emphasizes the need for arts education alongside the implementation of Common Core. Specifically, this is accomplished through the creation of professional development modules for teachers and administrators that incorporate the arts into Common Core instruction (California County Superintendents Arts Initiative, n.d.).

While CREATE CA is not the driving forces in California schools, the awareness of the need for an education system, focused on developing the "whole child" by using arts and arts-integrated curricula, is taking shape throughout the state.

\section{Why Arts Education?}

The arts have always been a significant part of human life. For most of human civilization, they have been inseparable from all aspects of personal, spiritual, and social life, and they expressed the close relationship between human beings and the natural and spiritual worlds. The people of prehistory created paintings of animals in their dwellings to recognize and celebrate the bond between them and the animals that provided food, and without which they could not survive. Dance, music, and theater were parts of religious rites and celebrations. John Dewey (1934/2005) described artistic expression in these terms: "Domestic utensils, furnishings of tent and house, rugs, mats, jars, pots, bows, spears, were wrought with such delighted care that today we hunt them out and give them places of honor in our museums. Yet in their own time and place, such things were enhancements of the processes of everyday life" (p. 5). 
The rise of nationalism and imperialism shifted the roles and places the arts occupied in society. From being perceived as fundamental parts of human experience, they became symbols of the greatness of a nation's cultural past. At times, this desire to glorify past artistic achievements was used to justify the conquering nations' pillaging of defeated nations' means of art production and of their artifacts. Dewey argues that the growth of capitalism was instrumental in promoting the ideas that art is separate from common life and that museums should be the primary place to display works of art (p. 7). He notes, "not only individuals, but communities and nations put their good taste in evidence by building opera houses, galleries, and museums.... These things reflect and establish superior cultural status while their segregation from the common life reflects the fact that they are not part of a native and spontaneous culture" (p. 7).

The notion that the arts exist only for art's sake, and that they should be placed "on a pedestal," further estranges them from common life. This view underlies the belief that the arts are reserved for an elite population. Today, works of art located in museums draw attention to the individualist and unique qualities of the work and its artist, separating her/him even further from the rest of the population. This accentuates the division between ordinary and esthetic experience (p. 8).

Most educators and school administrators see the production of art as solely creative expression, overlooking its potential role in the overall development of the mind, "as if the power of imagination were devoid of thinking or knowledge acquisition" (Efland, 2002, p. 7). Further, the arts in our schools are often seen as nothing more than entertaining and trivial occupations to offer to students only if time and resources permit, 
rather than being treated as serious subjects that require reflection and deep thinking (Beveridge, 2010; Chapman, 2004; Efland, 2002; Hetland et al., 2013).

Arts instruction is very important to a child's education because it teaches vital ways of seeing, thinking, imagining, and inventing. It also provides instruction in skills that are seldom addressed in other areas of the curriculum, such as reflection, self-criticism, and the willingness to experiment and learn from mistakes. These skills are essential for most $21^{\text {st }}$ century careers, but are not assessed by today's standardized tests (Hetland et al., 2013). Further, to describe the need for arts instruction in terms of what the arts can $d o$ for mathematics or reading suggests that the arts are supplemental to other types of learning, and places them in "the vulnerable position of being pushed far down in any constructed hierarchy of subjects" (Heath, 2014, p. 358).

Studio habits of mind. Hetland et al.'s research (2013) has focused on identifying the unique skills that the arts can teach, particularly the visual arts. Their work suggests that the arts cultivate the development of eight important competencies — which they call studio habits of mind - that may have positive impacts on student learning across the curriculum. These habits of mind, according to the researchers, are: (1) develop craftlearning to use tools and materials); (2) engage and persist in a task; (3) envision-using imagination to explore new ideas; (4) express - convey personal vision and meaning; (5) observe; (6) reflect; (7) stretch and explore_-taking risks and learning from mistakes; and (8) understand art worlds - finding connections and meaning between otherwise disconnected experiences, facts, and events (Hetland et al., 2013, p. 7). 
Hetland et al. (2013) argue that if the schools' primary focus is on preparing students to recall established facts, children will be ill-prepared to face global problems such as climate change, pandemics, and terrorism, issues which require novel and creative responses. Students who develop the habits of mind listed above learn to see patterns and envision new solutions where others see only isolated events. They will be the ones who will find the answers most needed in the future (p. 11).

The arts and Common Core. David Coleman (2013), one of the authors of the Common Core, highlights the connections between CCSS learning and arts instruction in a document titled Guiding Principles for the Arts Grades K-12. He says:

Meaningful appreciation and study of works of art begins with close observation. The Core Standards in Literacy similarly describe reading as the product of sustained observation and attention to detail. Particularly when encountering complex art, or reading the level of complex text, students will need to be ready for college and careers; students will need to learn to re-examine and observe closely.

As Coleman points out, arts-based learning and Common Core principles have many commonalities. Moreover, the studio habits of mind are closely aligned with the learning skills embodied in the CCSS. Table 1 shows how these habits of minds support Common Core English Language Arts and Math learning. This information is a part of the professional learning materials created by California County Superintendents Educational Services Association (CCSESA)'s Creativity at the Core initiative. The table was adapted from the CCSESA Arts Initiative website. 
Table 1

What is Core? What is Common?

\begin{tabular}{|c|c|c|}
\hline $\begin{array}{l}\text { Artistic /Studio } \\
\text { Habits of Mind }\end{array}$ & $\begin{array}{l}\text { English Language Arts } \\
\text { Common Core }\end{array}$ & $\begin{array}{c}\text { Math } \\
\text { Common Core }\end{array}$ \\
\hline Develop Craft & $\begin{array}{l}\text { Demonstrate grade-appropriate } \\
\text { command of reading and writing. }\end{array}$ & $\begin{array}{l}\text { Use appropriate tools strategically. } \\
\text { Reason through math processes in } \\
\text { concrete and abstract ways. }\end{array}$ \\
\hline Observe & $\begin{array}{l}\text { Listen and comprehend narrative } \\
\text { structure. Read written text } \\
\text { closely. }\end{array}$ & $\begin{array}{l}\text { Look closely for pattern, structure, } \\
\text { general method, and shortcuts. } \\
\text { Observe and maintain oversight of } \\
\text { process in order to attend to detail and } \\
\text { precision. }\end{array}$ \\
\hline Envision & $\begin{array}{l}\text { Interpret/analyze } \\
\text { Integrate/synthetize }\end{array}$ & $\begin{array}{l}\text { Gain insight into solutions through } \\
\text { contextualizing and decontextualizing } \\
\text { symbols relevant to processing and } \\
\text { computing problems. }\end{array}$ \\
\hline Express & $\begin{array}{l}\text { Construct arguments; produce } \\
\text { clear ideas in writing and speech. }\end{array}$ & $\begin{array}{c}\text { Model everyday applications of } \\
\text { mathematics. }\end{array}$ \\
\hline Engage \& Persist & $\begin{array}{l}\text { Read and write routinely. } \\
\text { Learn to revise. }\end{array}$ & $\begin{array}{l}\text { Make sense of problems and } \\
\text { persevere in solving them. }\end{array}$ \\
\hline Stretch \& Explore & $\begin{array}{l}\text { Activate prior knowledge to make } \\
\text { hypotheses and generate "what if" } \\
\text { questions. }\end{array}$ & $\begin{array}{l}\text { Consider and try new skills to create a } \\
\text { coherent representation or } \\
\text { understanding of the problem at hand. }\end{array}$ \\
\hline Reflect & $\begin{array}{l}\text { Respond to text with self- } \\
\text { awareness and awareness of the } \\
\text { context. }\end{array}$ & $\begin{array}{l}\text { Compare and reason with stated } \\
\text { assumptions, definitions and } \\
\text { constructed argument to analyze and } \\
\text { critique the reason for other } \\
\text { effectively. }\end{array}$ \\
\hline $\begin{array}{l}\text { Understand } \\
\text { Community }\end{array}$ & $\begin{array}{l}\text { Understand the history and field } \\
\text { of literary arts and architecture, } \\
\text { including popular culture. }\end{array}$ & $\begin{array}{l}\text { Understand the various math } \\
\text { discipline and their real life } \\
\text { applications. }\end{array}$ \\
\hline
\end{tabular}

Unfortunately, very few administrators and educators comprehend the relationship

between arts-based learning and Common Core. Most initiatives designed to connect the 
arts with other areas of the curriculum are overlooked or are unknown to those who influence change.

Arts education may reduce the achievement gap. Standardized testing is increasingly emphasized because it is considered by many to accurately measure academic success. Over the years, test scores have repeatedly demonstrated disparities in academic performance between student groups, regardless of whether these groups are defined by race (i.e. between Black and White, Latina/o and White, recent immigrant and White students (Ladson-Billings, 2006), or by socio-economic status (i.e. low-income family students versus high-income family students). Closing the achievement gap is one of the most examined education issues today (Ladson-Billings, 2006). Consequently, a significant body of literature is dedicated to studying this phenomenon in order to develop strategies to reduce such disparities. Although reforms have been implemented, such as reducing class sizes, creating smaller schools, expanding early-childhood programs, and improving the quality of teachers provided to poor and minority students, there has been little progress in reducing academic differences (Editorial Projects in Education Research Center, 2011).

Most arts disciplines are visual and do not require proficiency in a specific language for a student to be successful. Researchers have asserted that the feeling of being successful in one area helps students to deeply engage with their other academic work and may help them to believe they can succeed (Heath, Soep \& Roach, 1998; Hetland \& Winner, 2001; Kagan, 2009). These could be important factors in reducing the achievement gap. 
A large body of research, including the studies presented in "Champions of Change: The Impact of the Arts on Learning," has, in the last few decades, examined the effects of arts experiences on young people. These studies provided evidence that $\mathrm{K}-12$ students with a high level of arts participation in and out of school have better academic outcomes than students who lack these experiences (Fiske, 1999). One of the Champions of Change studies focused on the Chicago Arts Partnerships in Education (CAPE) initiative, which compared student achievement in 14 high-poverty Chicago schools over a period of four years. The CAPE project brought together arts and other local agencies, in partnership with teachers at all grade levels, to develop arts-integrated curricula i.e. combining instruction in an art form with specific instructional goals in other academic subjects. The CAPE schools demonstrated a significant improvement in student state scores compared to non-CAPE schools in the same neighborhoods (Caterall \& Waldorf, 1999).

Catterall (2009) analyzed data collected over a period of 10 years from the National Educational Longitudinal Survey (NELS) and was able to demonstrate that students from low socioeconomic backgrounds, English Language Learners (ELLs), and students with special needs have the greatest relative improvement in academic achievement when participating in the arts. The data also showed that ELL students were significantly more likely to pursue a college degree if they attended an arts-rich high school (Catterall, 2009). Along with having better academic outcomes, other studies demonstrated that young adults who had intensive arts experiences in high school were more likely to participate in civic activities than those young adults who did not (Heath \& Roach, 1999; Catterall, Dumais \& Hamden-Thompson, 2012). Catterall's research also revealed that 
low socioeconomic status (SES) students with arts experiences read newspapers, participated in local or school politics and government, and joined school service clubs four times more frequently than low SES students who did not have these arts experiences (Catterall, 2009; Catterall et al., 2012).

Arts integration. A growing number of studies continue to show evidence of important links between cognition, social and emotional development, and learning in the arts (Duma. 2014; Ingram \& Seashore, 2003; Melnik, Withmer \& Strickland, 2011; Rabkin \& Redmond, 2006; Robinson, 2013). Further, some studies have compared standalone arts programs with programs that integrate concepts and skills from the arts into other academic areas. They reveal that the most powerful effects are found in programs that integrate the arts with the core curricula (Brouillette, 2012; Eger, 2015; Pruit, Ingram \& Weiss, 2014; Sousa, 2006). Arts integration, research shows, prompts both students and teachers to rethink how they regard arts instruction and create conditions that are ideal for learning (Sousa, 2006). Additionally, Melnik et al. argue that arts-integrated learning provides students with active and meaningful roles in the classroom and connects schoolwork to the students' own lives. Such interlacing of art learning into other content areas reinforces non-arts learning and has an increased impact on overall student achievement (p. 156).

Across the country, several K-12 public schools have adopted arts-integrated curricula, for example, the "Turnaround Arts" program. The President's Committee on the Arts and the Humanities (PCAH) created this program in 2012 in order to test whether the arts can provide a higher-quality learning environment and improve student 
outcomes. The eight schools that took part in the pilot phase all demonstrated significant progress in student achievement, including an increase in attendance rates and dramatically reduced suspensions. The schools' math and reading scores were much better than comparable schools' scores in their state or districts that were undergoing a "turnaround" process but not using the arts (PCHF, n.d.). The Turnaround Arts program is the first federal effort to utilize arts education to improve some of the country's lowestperforming schools, and shows promise in reducing the achievement gap. First Lady Michele Obama announced in May, 2014 that the program would be extended to 35 schools in 10 states, including California (Lynch, 2015).

\section{Arts Education Partnerships}

Partnerships between schools and arts organizations have been popular since the 1960s (Bodilly, Augustine \& Zackaras, 2008; Remer, 2010). In the last decade, arts education partnerships have flourished in urban settings where arts organizations are numerous, and teaching artists (TAs) are available (Bodilly et al., 2008; Burnaford, 2007). Teaching artists have various roles in schools: they may work in stand-alone programs as guest instructors in a specific art form, or they may partner with classroom teachers to integrate the arts with non-arts content.

The President's Committee on the Arts and the Humanities (2011) defines teaching artists as "hybrid professionals" (p. 41). These artists provide expertise in their art disciplines and teach arts skills, and often lead arts integration or projects-based learning activities, such as bringing visual art and music into the study of world cultures. They 
work as partners with classroom teachers to plan and deliver art lessons and introduce students to the life of a working artist.

Models of arts partnerships. Literature suggests that the depth of teaching artists' support is an important factor that helps characterize the implementation structure of the programs. Freeman, Seashore \& Werner (2003) enumerated five different implementation models: the residency model, the elaborate residency model, the capacity-building model, the co-teaching model, and the concept across the curriculum model. Three of these models most frequently found in arts education partnerships are:

1. The residency model: a school or teacher invites one or more artists or arts organizations into the classroom for a specified period of time. The purpose is to give students a wide range of arts experiences the staff cannot provide. This model does not necessarily address curricular goals and there is no collaboration between teachers and artists.

2. The capacity-building model: here, the goal is to prepare teachers to use an art form in their teaching practice. The artist's role is to instruct the teachers, while the classroom teacher participates and assists the TA, with the goal to gain expertise in the process of teaching the art form. Teachers, alone or with the TA, identify ways to integrate the art form's skills and concepts with the non-arts subjects.

3. The co-teaching model: in this model, teachers and artists work together to integrate arts skills and concepts into other areas of the curriculum. They aim to construct lessons in such a way that each subject reinforces the others. The 
teacher and artist create lessons together which guide the artist during classroom sessions that focus on the arts, and define what the teacher will do when the artist is not present (Goff and Ludwig, 2013).

Characteristics of effective partnerships. Large-scale partnerships such as Changing Education Through the Arts (CETA), Chicago Arts Partnerships in Education (CAPE), A+ Schools, and Arts for Academic Achievement, are well-established, highly effective, and have been thoroughly documented (Caterrall \& Waldorf; 1999; Duma, 2014; Freeman, Seashore \& Werner, 2003; Horowitz, 2004; Ingram \& Seashore, 2003; Miller, Wake \& Wittingham, 2016; Scripp \& Paradis, 2013; Siedel, 2000). From these studies, the literature identifies two distinct types of arts education partnerships:

1. Simple transactions: an artist or an arts organization offers an arts program and the school purchases the program. In this instance, the school (the consumer) has no input into the design of the arts program and the artist or arts group (the provider) does little or nothing to adapt the program to a specific school site (Dreeszen, 1992; Rowe, Werber Castaneda, Kaganoff \& Robyn, 2004).

2. Joint ventures: the school and the arts organization work together to create arts instruction that fits the school's and students' needs. The program can be a onetime event or it can become an ongoing collaboration. This model focuses on teaching and learning, rather than offering simple exposure to the arts (Dreeszen, 1992; Rowe et al., 2004).

Dreeszen (1992) identifies a third type of partnership, which he calls “institutionalized collaborations." This model involves many parties, and the connections 
between the schools, arts organizations and artists are complex and require a separate management structure. The collaboration becomes a corporate entity with its own mission, staff, budget, and programs. Two examples of this are the Kennedy Center's CETA program and Los Angeles's Arts for All initiative.

Dreeszen (1992) further states that effective partnerships develop over time, noting, "potential partners need to get acquainted, build trust, and agree upon shared goals before they act” (p. 3). School and arts organizations must also establish a support system that will allow the partnership to grow and mature. Several studies have examined why some partnerships survive initial funding and grow, while others disappear. These studies show that successful partnerships consistently present the same features:

- Shared values and goals that address the needs of the students and the schools

- Effective communication between partners and joint program planning

- Ongoing program evaluation for quality improvement

- Leadership roles played by key stakeholders (i.e. principals, teachers, parents, and community leaders in education and the arts)

- Adequate funding, resources, and support (Freeman, Seashore \&Werner, 2003; Horowitz, 2004; Ingram \& Seashore, 2003; Myers, 2001; Rowe et al., 2004; Seidel, 2000)

- Personal commitment and sense of ownership (Seidel, 2000)

Quality in arts education. Anne Bamford (2010), in her article "Issues of Global and Local Quality in Arts Education," discuss the issue of excellence in arts education, a topic that is rarely addressed in research, as most studies tend to focus on the impact of arts 
programs, rather than on the quality of arts learning experiences. Bamford examines the key components for achieving quality in the arts in the context of arts partnerships, which are becoming key providers of arts instruction, and considers the issue from two different perspectives. In the first one, which she calls the "consumer-based approach" (p. 53), the schools (the consumers) must define what qualifies as a "good" art experience and determine criteria to be used to select an arts organization. Some schools and teachers choose artists that clearly understand the culture and the context of the students, faculty, and the school community. These artists must be skilled in planning and organization, and able to communicate ideas, information and values. Other schools may approach quality in terms of the artist's impact on community-building, that is, does the artist promote outreach to the parents and the community and contribute to the school's identity, its "brand"? Still other schools find the real value of bringing an "outside" or professional artist into the school resides in providing professional learning opportunities for the school staff. This can result in an increased awareness of what the arts can offer in terms of creativity, critical thinking and other habits of minds; over time, the artist may help transform the school's culture.

In the second perspective, the "provider-based approach" (p. 55), Bamford examines quality from the arts organizations' point of view. She outlines the factors arts experts and peers in the field take into account when conducting evaluations of arts programs. To these experts, quality is measured in terms of merit, that is, the intrinsic beauty or artistry of the project, and worth, its applicability, usefulness, contribution, and desirability to a given school or educational context, i.e., is what the arts program brings to the teachers 
and students relevant? No matter which method is used to assess the quality of arts programs and partnerships, Bamford argues that ultimately all efforts must endeavor to provide children with arts experiences that are the most suitable for and relevant to them and "right first time" (p. 52), i.e. include markers that usually indicate quality practice in four different domains: learning, pedagogy, community dynamics, and environment.

\section{Summary of Chapter}

This chapter provided a context for the present study and examined the existing literature on arts education in three areas: federal and state education policies since the 1960s, the impact of arts education on student outcomes, and arts education partnerships. The arts foster creativity, imagination, original thinking, and problem-solving skills. They increase self-confidence, encourage self-reflection, and develop cultural awareness and empathy. All these skills are vital to succeed in the $21^{\text {st }}$ century. Yet, budget cuts and federally-mandated accountability continue to marginalize arts instruction, keeping the arts peripheral to student learning. Moreover, the arts are often seen as "recess" or "fun" activities, rather than being viewed as essential to a child's education. In that context, local arts organizations are taking a prominent role in providing schools with arts programs, particularly at the elementary level. 


\section{Chapter 3}

\section{Methods}

What counts as knowledge depends on perspective, time, interest, method, and form of representation. What has been recognized-a lesson the arts teach-is that the choice of an approach to the study of the world is a choice of not only what one is able to say about the world, but also what one looks for and is able to see. Methods define the frames through which we construct the world.

-Elliot Eisner, The Arts and the Creation of the Mind

\section{Introduction}

Chapter Three provides a detailed description of the study methodology. The chapter begins with briefly restating the problem and the research questions formulated in Chapter One; it continues with a discussion of the research design, sampling strategies, data collection procedures, and analysis methods. The chapter also addresses the procedures used to establish trustworthiness.

\section{Restatement of the Problem}

Despite abundant literature that underscores its benefits (Brouillette, 2012; Burton, Horowitz \& Abeles, 1999; Duma, 2014; Fiske, 1999; Catterall, Dumais \& HamdenThompson, 2012; Peppler, Powell, Thompson \& Catterall, 2014; Pruit, Ingram \& Weiss, 2014; Sousa, 2009) and education policies that define the arts as core academic subjects (NCLB, ESSA), arts instruction in public schools occupies a small place in the curriculum. Lack of funding (Chapman, 2004; Gadsden, 2008), and the schools' focus on academic subjects that are assessed through standardized testing ( $\mathrm{Au}, 2007$; Baker, 2012; Berliner 2011; Beveridge, 2010; Freedman, 2007) are the main factors that explain its decline. A 2007 landmark study led by SRI International revealed that few California 
elementary schools were able to offer arts instruction in the four arts disciplines defined in the VAPA standards. Among these schools, $68 \%$ had turned to local arts organizations to provide arts instructions. Nearly all partnerships were funded with private donations, creating inequalities in access to these programs. The arts partnerships varied in nature, ranging from single events (organizing field trips to performances or exhibits) to artistsin-residency programs and professional development for teachers. While these partnerships filled a gap in arts education and offered students rich and authentic arts experiences, they were supplemental to the curriculum, not full-fledged arts programs. Positive though they were, arts partnerships did not inspire schools to develop their own, more complete arts programs, and did not foster the development of schools' own capacities for teaching the arts (Woodworth, Petersen, Kim \& Tse, 2009).

The intent of this study was to gain a deep understanding of how arts partnerships worked on an everyday basis, to identify the challenges they faced, and the conditions in which they could grow and thrive. To that end, the study examined and compared three arts partnerships that involved two arts organizations and three elementary schools in the South San Francisco Bay Area. Through in-depth interviews and classroom observations, this study explored the following question: How did the various institutional actors (classroom teachers, school administrators, arts organization staff, teaching artists, and arts organization staff) describe their experiences working within an arts partnership? Specifically:

A. What benefits did the various institutional actors listed above derive from the partnership? 
B. What burdens or obstacles did the participants face when they were involved in the partnership?

C. What strategies did they utilize to navigate and manage the issues that arose from the partnership?

\section{Research Design}

A pragmatic inquiry model, rooted in Dewey's (1934/2005) theory that knowledge is constructed from experience- - i.e. the "result of interaction between a live creature and some aspect of the world in which he lives" (p.45) — informed this research. Researchers who adopt a pragmatist framework are not committed to one system of philosophy and reality (Creswell, 2013). Rather, they embrace eclecticism and pluralism, and find that examining conflicting theories is a way to construct meaning and knowledge of the world in which we live (Johnson \& Onwuegbuzie, 2004). They argue that people's experiences and perceptions of the world become "truth" by a continuous process of adaptation to their environments (Stark, 2014). Through pragmatism as a mode of inquiry, researchers aim to gain a deeper understanding of a particular situation, experience, or phenomenon by "acting and observing in the research site, and then evaluating and making sense of the results towards a given goal" (Stark, p.89). Their interest centers on the outcomes of the research, i.e. "the actions, situations, and consequences of the inquiry," rather than preexisting conditions, and they look for applications and solutions to problems (Creswell, 2013, p. 28). As a consequence, pragmatist researchers utilize many approaches to collecting and analyzing data in order to best answer their research question (Johnson \& Onwuegbuzie, 2004). 
Since my principal interest was to deeply understand a phenomenon (arts education partnerships), I chose to utilize qualitative inquiry methods, studying data collected in three elementary schools. This research approach was best suited for this project for several reasons. It enabled me to 1) observe and study a phenomenon in the context in which it occurred; 2) interact with the participants and observe behaviors; 3) highlight their experiences with and perspectives on the partnerships; and 4) identify the multiple factors involved in the phenomenon and the complex interactions between them (Cresswell, 2013; Yin, 2014).

\section{Research Methodology}

Sampling strategy. Purposeful sampling is commonly used in qualitative research because it allows the researchers to select study sites and participants that "purposefully inform an understanding of the research problem" (Cresswell, 2013, p. 156). I employed maximum variation sampling — a sampling strategy that aims to maximize the diversity of the sites and participants, in order to present a broad range of perspectives - to the extent it was possible. The brief time frame I had for gathering the data (mid-November to midDecember, 2016), as well as the fixed schedule of each art partnership (that is, I could only observe the arts residencies that were in progress) were major constraints. However, studying three different arts partnerships permitted me to conduct a cross analysis and identify themes, both similar and dissimilar, across the arts residencies. Therefore, I was able to collect data and present findings that reflected differences and multiple perspectives, creating a "robust" and "compelling" study (Yin, p. 57). 
Research sites. I established several criteria for the selection of the study sites. First, I chose elementary schools that were located in suburban areas, where many arts education partnerships existed. Second, practicality and convenience were important factors; all three schools and their arts organization partners were located in the area in which I lived and worked. I selected two arts organizations, which I named the Center of the Arts (CftA) and Valley Arts Studio (VAS), because they had both provided arts education to schools for many years (all names used in the study, whether persons, arts organizations, or schools, are pseudonyms). Their programs differed from one another: the Center of the Arts promoted integrated learning and student-centered pedagogies, whereas Valley Arts Studio focused on delivering arts instruction in the visual and performing arts. Another important consideration was my own familiarity with the programs each organization offered: I served on the education committee of the Center for the Arts, and I worked as an afterschool visual arts instructor for Valley Arts Studio for two years, from 2002 to 2004 . These connections made it easy to contact the education directors and to recruit their organizations for my research.

Each director helped determine the school sites. Two schools, Cypress and Orchard Elementary, had a partnership with the Center for the Arts. The third school, Shadow Brook Elementary, partnered with Valley Arts Studio. Each of the three partnerships presented a distinct residency model due to 1) the teaching artists' arts disciplines, 2) the student population the partnership reached; and 3) the delivery model of arts instruction. Table 2 describes the characteristics of each arts partnership. 
Table 2

Characteristics of Each Art Partnership and Residency Observed

\begin{tabular}{|c|c|c|}
\hline \multicolumn{2}{|c|}{ Center for the Arts } & Valley Arts Studio \\
\hline \multicolumn{2}{|c|}{ Arts-Integrated Learning } & $\begin{array}{c}\text { "Rotating Arts Wheel" } \\
\text { Dance, Music, Theater, and Visual Arts } \\
\text { instruction }\end{array}$ \\
\hline \multicolumn{2}{|c|}{ 10-week residency } & 6-week residency for each art discipline \\
\hline \multicolumn{2}{|c|}{ District-wide partnership } & District-wide partnership \\
\hline \multicolumn{2}{|c|}{ Single grade level ( $2^{\text {nd }}$ grade $)$} & TK through $5^{\text {th }}$ grade \\
\hline \multicolumn{3}{|c|}{ Observed Residencies } \\
\hline Orchard Elementary & Cypress Elementary & Shadow Brook Elementary \\
\hline $\begin{array}{l}\text { Storytelling and } \\
\text { Movement }\end{array}$ & Visual Arts \&Science & Visual Arts curriculum \\
\hline Four $2^{\text {nd }}$ grade classes & Four $2^{\text {nd }}$ grade classes & Classrooms observed: $1^{\text {st }}$ through $4^{\text {th }}$ grade \\
\hline
\end{tabular}

The student population varied greatly at each site. Cypress and Shadow Brook served primarily socioeconomically disadvantaged students and English Language Learners, while Orchard Elementary served more affluent, native English-speaking students. Table 3 shows the student demographics at each school site. 
Table 3

2015-16 Student Population Characteristics per Site

\begin{tabular}{|l|c|c|c|}
\hline & $\begin{array}{c}\text { Orchard } \\
\text { Elementary }\end{array}$ & $\begin{array}{c}\text { Cypress } \\
\text { Elementary }\end{array}$ & $\begin{array}{c}\text { Shadow Brook } \\
\text { Elementary }\end{array}$ \\
\hline Number of students & 572 & 614 & 545 \\
\hline Student enrollment by group & & & \\
\hline Hispanic or Latino & $9.6 \%$ & $56.2 \%$ & $56 \%$ \\
\hline Asian & $24.5 \%$ & $9.8 \%$ & $17.4 \%$ \\
\hline Filipino & $0.9 \%$ & $3.7 \%$ & $3.5 \%$ \\
\hline White & $44.8 \%$ & $17.8 \%$ & $15.2 \%$ \\
\hline American Indian or Alaska native & $0.2 \%$ & $0 \%$ & $0 \%$ \\
\hline Black or African American & $0.3 \%$ & $4.2 \%$ & $1.7 \%$ \\
\hline Native Hawaiian or Pacific Islander & $0.5 \%$ & $0.7 \%$ & $0.6 \%$ \\
\hline Socioeconomically disadvantaged & $7.7 \%$ & $56.5 \%$ & $58.3 \%$ \\
\hline English learners & $14.9 \%$ & $45.6 \%$ & $52.1 \%$ \\
\hline Students with disabilities & $5.1 \%$ & $11.7 \%$ & $9.2 \%$ \\
\hline
\end{tabular}

Research Participants. In order to look at the arts partnerships from different angles, I invited all the individuals who had a role in the partnerships (i.e. classroom teachers, teaching artists, school principals, and arts organization staff) to participate in the study. The two arts organization directors facilitated my introduction to the school principals, with whom I met to present and discuss my study. The principals then relayed this information to their teachers, who responded favorably to my request to observe their classrooms and to interview them. The responses were particularly positive at Orchard and Cypress Elementary. At Shadow Brook, only two of the five teachers I observed agreed to be interviewed, a $1^{\text {st }}$ grade and a $2^{\text {nd }}$ second grade teacher. The total number of participants was 21 . Table 4 shows the participants' positions and the institution to which they belonged. All participants were asked to review and sign a consent letter before I 
began the classroom observations interview meetings. The consent letter is presented in Appendix A.

Table 4

Participant Characteristics per Institution

\begin{tabular}{|c|c|c|c|c|c|}
\hline & \multicolumn{3}{|c|}{ Schools } & \multicolumn{2}{|c|}{ Arts organizations } \\
\hline & $\begin{array}{c}\text { Orchard } \\
\text { Elementary }\end{array}$ & $\begin{array}{c}\text { Cypress } \\
\text { Elementary }\end{array}$ & $\begin{array}{c}\text { Shadow } \\
\text { Brook } \\
\text { Elementary }\end{array}$ & $\begin{array}{l}\text { Valley Arts } \\
\text { Studio }\end{array}$ & $\begin{array}{l}\text { Center for } \\
\text { the Arts }\end{array}$ \\
\hline School Staff & & Principal & Principal & & \\
\hline $\begin{array}{l}\text { Classroom } \\
\text { Teachers }\end{array}$ & $\begin{array}{c}4 \\
\left(2^{\text {nd }} \mathrm{Gr}\right)\end{array}$ & $\begin{array}{c}4 \\
\left(2^{\text {nd }} \mathrm{Gr}\right)\end{array}$ & $\begin{array}{c}5 \\
\left(1^{\text {st }}, 2^{\text {nd }}, 3^{\text {rd }}\right. \\
\left.\text { and } 5^{\text {th }} \mathrm{Gr}\right)\end{array}$ & & \\
\hline $\begin{array}{l}\text { Teaching } \\
\text { Artists }\end{array}$ & 1 & 1 & 2 & & \\
\hline $\begin{array}{l}\text { Arts } \\
\text { organization } \\
\text { Staff }\end{array}$ & & & & $\begin{array}{c}\text { Executive } \\
\text { Director } \\
\\
\text { Director of } \\
\text { During School } \\
\text { Programs }\end{array}$ & $\begin{array}{l}\text { Executive } \\
\text { Director } \\
\text { Director of } \\
\text { Education }\end{array}$ \\
\hline
\end{tabular}

\section{Data Collection Procedures}

Qualitative research relies on several methods for gathering data, i.e. conducting observations and interviews, reviewing documents, and examining artifacts (Stake, 2010). Accordingly, my primary sources of data were direct observations, face-to-face interviews, and informal conversations I had with the classroom teachers and/or the teaching artists on the days I visited the schools. Classroom observations were conducted while teaching artists were leading arts activities. Other sources of data, including research sites' websites and photographs of the schools' sites and student work, provided 
general information on each institution and gave additional context to the study. These additional resources are described in a later section of this chapter.

Observations. Field observations, like interviews, were important instruments that were used to collect data in qualitative research (Yin, p. 113). They provided additional and highly valuable information about the topic being studied, and enabled me use of my senses — sight, sound, and touch - to make meaning of the actions and behaviors unfolding before me (Cresswell, p. 166). I conducted 24 hours of observation in 14 classrooms across the three sites. I was able to observe two classes three times, over a period of several weeks, at Cypress Elementary. Table 5 details the observation process at each site.

Table 5

Detail of Observations Across the Schools Sites

\begin{tabular}{|c|c|c|}
\hline \multicolumn{3}{|c|}{ Observations } \\
\hline Orchard Elementary & Cypress Elementary & Shadow Brook Elementary \\
\hline $\begin{array}{l}\text { One day of observation } \\
\text { (last day of residency): }\end{array}$ & $\begin{array}{l}\text { Observations conducted on } \\
\text { three different days; occurred } \\
\text { mid-residency: }\end{array}$ & $\begin{array}{l}\text { Observations conducted on } \\
\text { two separate days; occurred } \\
\text { mid-residency: }\end{array}$ \\
\hline $\begin{array}{l}\text { - Four } 2^{\text {nd }} \text { grade } \\
\text { classrooms } \\
\text { - Debrief meeting about } \\
\text { the art session } \\
\text { (Teaching artist and } 3 \\
\text { classroom teachers) }\end{array}$ & $\begin{array}{l}\text { Four } 2^{\text {nd }} \text { grade } \\
\text { classrooms }\end{array}$ & $\begin{array}{l}5 \text { classrooms } \\
\text { - One } 1^{\text {st }} \text { grade class } \\
\text { - Two } 2^{\text {nd }} \text { grade classes } \\
\text { - One } 3^{\text {rd }} \text { grade class } \\
\text { - One } 4^{\text {th }} \text { grade class }\end{array}$ \\
\hline Time observed: 5 hours & Time observed: 14 hours & Time observed: 6 hours \\
\hline
\end{tabular}

While conducting my observations, I took on different roles. Strictly an observer at Orchard and Shadow Brook, I sat in a corner of the room taking notes, occasionally 
walking around the students' tables to take photographs of their work. At Cypress, I had the same role on the first day of my observations. However, during the next day of observations, I noticed that a majority of students had difficulties with the art activity (using an iPad app to create a digital poster on water conservation, based on a paper collage the students had created during the previous lesson). Many of these students were not familiar with the iPad and struggled with spelling and typing words to include in their posters. A visual arts educator myself, I felt compelled to assist the teaching artist and the classroom teacher. I became a participant-observer, a role I maintained until my observations at Cypress were completed.

My active participation in the residency lessons had a consequence I had not expected. As a participant-observer, I was more easily able to establish relationships with the classroom teachers. Due to this connection, the Cypress teachers were more willing to participate in an interview and more generous of their time, as opposed to the teachers with whom I had been solely an observer.

Interviews. All interviews were conducted after the observations and were spread over a period of two months, primarily due to scheduling issues. The interviews were of two types: individual interviews with the school principals, the teaching artists, and the arts organizations staff $(\mathrm{n}=10)$ and group interviews with the classroom teachers (one group interview at each school site, $n=3$ ). The total of the persons interviewed was $n=21$. The length, location, and the number of participants in each group interview varied. Table 6 shows the characteristics of each interview, that is, the duration of each interview, where they took place, and the number of participants. Most of the teachers preferred to 
participate in a group interview rather than a one-on-one interview, possibly due to time constraints. The Center for the Arts teaching artists were present during the group interviews at Cypress and Orchard, which allowed me to observe how teachers and teaching artists interacted outside the classroom setting. 
Table 6

Interview Characteristics and Number of Interviewees per Site

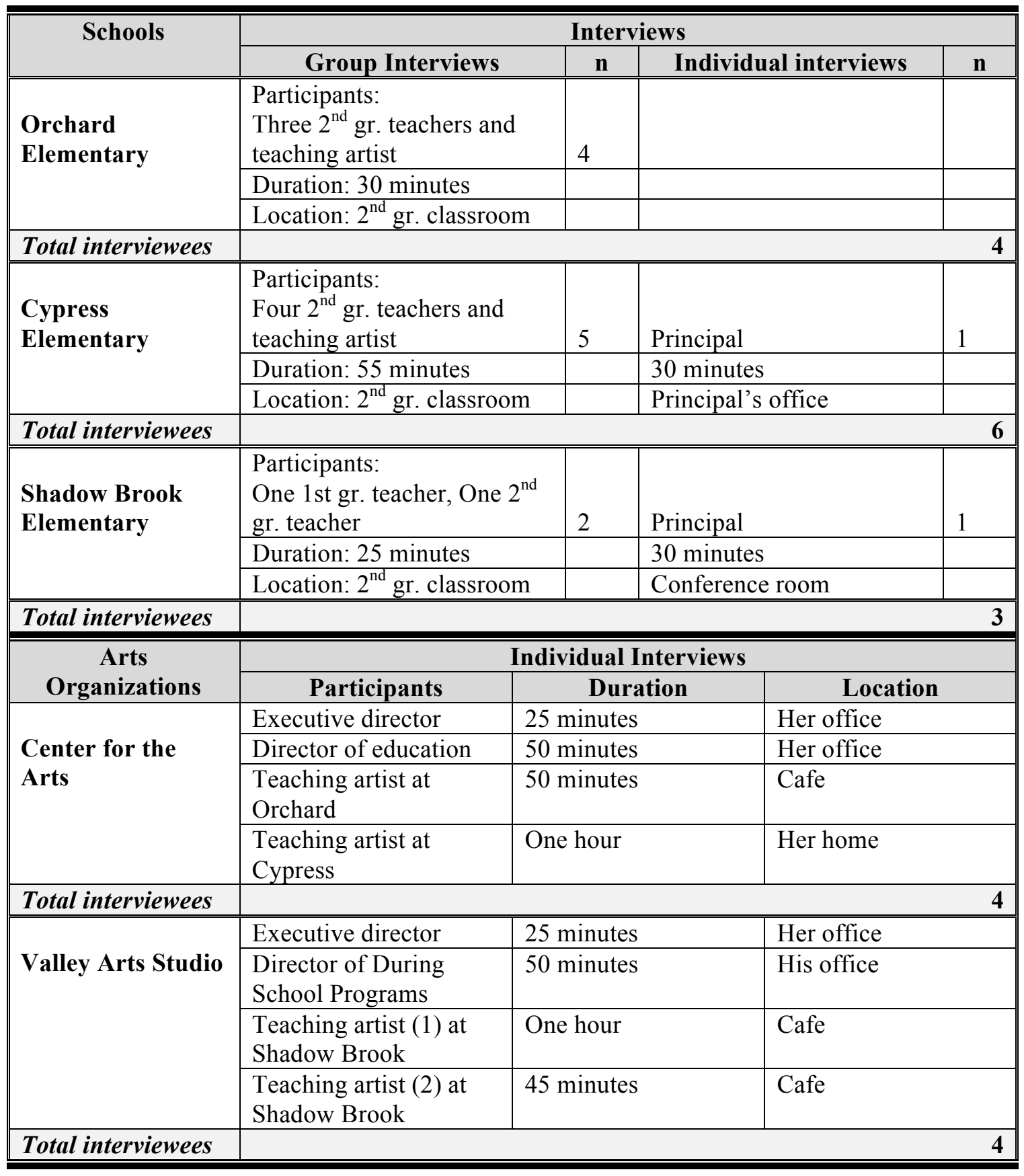




\section{Instrumentation}

Interview protocol. Interviews serve several purposes in qualitative research. They provide data the researcher could not obtain through his/her own observations, as well as the unique opinions and comments of the participants on the studied phenomenon. For these reasons, qualitative interviews are "guided conversations rather than structured queries" (Yin, p. 110). The interviewer's role is to ask probing questions that "open up topics" (Riessman, 2008, p. 25) and elicit genuine and elaborated responses from the interviewees.

I utilized a semi-structured interview protocol for the individual and group interviews that consisted of a few open-ended questions. The questions were designed to align with the research questions and grouped by categories (i.e. general questions, organizational questions, curriculum questions, challenges and strategies questions, benefit questions, and school culture questions). For each theme, the questions were tailored to the position and the role of participant within the arts partnership and included experience and opinion questions. Individual and group interview protocols can be found in Appendices $\mathrm{B}$ and $\mathrm{C}$. All interviews were audiotaped to ensure accuracy in reporting the interviewees' responses. A third party transcribed the interviews verbatim.

Observation protocol. Direct observations enable the qualitative researcher to record the "who, what, where, and why" (Stake, p. 90) of a particular situation simultaneously. Similar to the interview protocol, the observation protocol was designed to gather information germane to the research questions. It listed what was to be observed with 
regard to the actions and behaviors of the people in the classrooms (i.e. teaching artist, classroom teachers, and students). The protocol template is shown in Appendix D.

Field notes. During my observations at Orchard, Shadow Brook, and part of my observations at Cypress, I primarily took descriptive notes, occasionally jotting down thoughts and questions that came to mind while I was making my observations. On the two days I was a participant-observer at Cypress, I had no time to take notes. I wrote my field notes belatedly, relying on memory to recall all that I had seen while I was assisting students, as well as the content of my informal conversations with the teaching artist as I helped her with material preparation. I sorted and organized my field notes into a log for each school site, allowing me to begin to develop a narrative that combined field observations, reflexive notes, and participants' comments. Appendix E presents an example of this process.

Review of documents. According to Yin (2014), "a good case study relies on as many sources as possible" (p. 105). Various sources of data provided additional information. They were: 1) public information about the research sites I obtained through Internet searches, such as the Schools' Accountability Report Cards (SARCs); 2) the teaching artists scheduled at each school site; 3) e-mail correspondence between the teachers and the teaching artist at Orchard, 4) feedback from the classroom teachers regarding the previous year's residency at Orchard, which was with the same teaching artist; 5) the results of a study the Center for the Arts conducted when their Teaching Artist Program was piloted at Cypress; 6) teaching artists contracts; 7) photographs I took of the schools' buildings, arts rooms, and student work; and 8) the schools' campus maps. 
The examination of these documents and artifacts generated an array of data, which, added to the information collected through interviews and observations, enabled me to create a comprehensive depiction of the phenomenon I set out to study, that is, arts education partnerships, in all their complexities.

\section{Data Analysis Strategies}

Qualitative analysis consists of examining and organizing the data into categories through a process of coding, i.e. "reducing the data into meaningful segments and assigning names for the segments," (Creswell, 2013). These segments are then combined into broader themes to produce "empirical-based findings" (Yin, 2014). As a novice researcher, I followed Yin's suggestion to "play with the data," and his recommended strategy to "work the data from the ground up" (p. 135-136), searching for patterns, insights, and concepts that seemed promising.

The process of coding included two cycles: First, I read all the interview transcripts while listening to the recordings and created initial codes. This helped me to recall and visualize the expressions, gestures and body language of the participants, write descriptive topics in the margins of the transcripts, and to note ideas and concepts that came to mind as I was reading and listening (Creswell, 2013; Yin, 2014; Charmaz, 2014). I then read and listened several more times to ensure I interpreted the data accurately. Through this process, I reviewed my initial codes, organizing and condensing them to align with the research questions.

My analytic strategy was informed by Reissman's (2008) thematic analysis and Charmaz's (2014) grounded theory coding methods. I adopted Reissman's approach, and 
focused on the data content, paying attention to the participants' narratives, i.e. what was told rather than how these narratives were told (p. 74). I attributed codes to large sections of text rather than coding each line of text, as grounded theory researchers would do, aiming to interpret the story told as a whole (p. 57). I followed Charmaz's, recommendation to code segments with gerunds, in order to detect processes and action in the data, a method, she underlines, that keeps the researcher close the data and enables him/her to begin the analysis from an insider's perspective. As an example of gerund, I used the code "building relationships," instead of "relationships," to describe how various participants interacted and developed interpersonal connections. The final coding, which is presented in Appendix F, included both descriptive and gerund codes.

I began coding the interviews manually, making color-coded notes on the transcripts printed copies. I soon realized that due to the large amount of text I had (over 200 pages of transcript), this process was impeding my progress in making sense of the data. I opted to use a computer-assisted tool (Dedoose software) for my second phase of coding. In retrospect, this approach was invaluable for managing and organizing the codes as well as easily retrieving specific material (words, excerpts, and codes) when needed.

\section{Establishing Trustworthiness}

Construct validity. Qualitative research is "interpretive, experimental, situational, and personalistic" (Stake, 2010, p. 15) and depends largely on researchers analyzing the meanings of what they see and hear. Presenting an accurate interpretation of the participant's experiences, devoid of the researcher's own biases, is critical in order to produce good qualitative research. To that effect, qualitative researchers have developed 
several strategies for validating their findings. Triangulation (comparing data from multiple sources to provide corroborating evidence) and member checking (asking the participants to review the researcher's findings and interpretations) are widely used for this purpose. I utilized both strategies in my study. I compared the participants' statements with field notes and the various documents I had collected to support my findings. I asked the participants to review my analysis each time I needed clarification about their interview responses or I questioned my interpretation. This double-checking was accomplished through e-mails, telephone conversations, and in-person meetings.

Additionally, peer reviewing and turning to what Stake (2010) calls "critical friends" (p. 128) added another check to my research process. My faculty advisors, with whom I met regularly, offered support and guidance. They supplied vital critique throughout the study, questioning my research protocols and methods, as well as my interpretation and of the data and discussion of findings. Two more persons - my editor and my son, a $\mathrm{PhD}$ candidate in chemistry - were invaluable in reviewing my drafts, commenting on the clarity, accuracy, logic, and flow of my writing.

Limitations (internal validity). Due to the nature of arts residencies, which occurred over short period of time (6-10 weeks out of the school year) and delays in obtaining IRB approval, I was not able to conduct as many observations as I had planned. At Orchard, for example, I was able to observe only the last day of the residency. By comparison, the time I conducted my observations at Cypress and Shadow Brook occurred during midresidencies, which allowed me to visit the schools several times. 
I was more successful with scheduling the interviews, in which all the participants agreed to participate. Arts organizations staff and teaching artists, particularly, were generous of their time and supported my research in any way they could. While the Orchard and Shadow Brook teacher interviews were brief, approximately 30 minutes, the teachers interview at Cypress, the school where I had been a participant-observer, lasted longer that we had agreed upon: nearly an hour. Further, on the day of the interview, I was surprised to find that all four $2^{\text {nd }}$ grade teachers were there, even a teacher I had never met and observed. I felt these teachers enjoyed being together and discussing the CftA partnership. My questions were like prompts for them, which they answered and then discussed freely and genuinely between them. I felt they found a safe place to express their thoughts and ideas about the residencies, as though they had not had many opportunities to do so before this interview. This was a powerful and moving experience for me.

One concern with qualitative research is the biases the participants may introduce into their comments and responses. The fact that I had no prior connection to the participants, except the VAS Executive Director and the Director of Education at CftA, and that I was not an employee of any of the research sites, may have limited the impact of this issue, since the participants would not gain or lose anything from speaking with me. For these reasons, I trusted the participants to share their true thoughts and opinions, rather than telling me what they thought I wished to hear. In all, despite the short time available for observations and the possibility that the participants may not have been completely 
honest in their statements, I was able to gather enough data to fully explore the complexity of each partnership and present rich and detailed descriptions of them.

Self-disclosures. Stake (2010) contends that qualitative researchers care about the situations they study and are driven by the desire to improve how they work. Due to the nature of qualitative research, researchers themselves are instruments; they observe environments, actions, and behaviors through their own experiences and thus, may "unintentionally play a subjective role in the study" (p. 20). For him, inserting empathy and advocacy into one's research may be positive, provided the researcher analyzes and interprets the data with an objective mind. I find myself in the researcher's profile Stake portrays. As a visual arts educator and an ardent proponent of arts education, I may have introduced bias into my research.

Although all the study participants welcomed me, I felt more "at home" with the arts people than with the school staff. Further, during my visits to the schools, it seemed that the staff and faculty were continuously "running," and did not have much time to dedicate to my research. By comparison, the arts organizations staff and the teaching artists showed a deep interest and were available each time I reached out to them. The significant amount of time and attention given by the arts people generated a great deal of data, which may be reflected in the findings in that the perspectives from the arts side are more developed than from the school side.

My interactions with the participants-teachers, particularly during the interviews, made me realize that the picture I had created in my mind of their roles and responsibilities was incomplete and uninformed. Through my conversations with them, I 
was better able to understand what these roles and responsibilities were, as well as the many demands that were put upon them. Listening to the teachers explaining their constraints helped me to see that, contrary to the freedom of the teaching artist who can create her own curriculum based on her interest, teachers have to do things they do not like. This was eye-opening for me. This new understanding changed my perceptions of the school environments in which I work, and gave me a fuller appreciation of the challenges my teachers-colleagues face every day.

Recognizing my bias toward arts education, I did my best to conduct interviews and observations with an objective, impartial, open, and curious mind. I recruited participants who occupied various positions and responsibilities within the partnerships in order to give a voice to everyone involved and present multiple perspectives. I strove to accurately present the points of view of the study participants, rather than my own.

Delimitations (external validity) Qualitative researchers study people in their natural environments. For that reason, the rich, detailed representation I created of each arts partnership makes this research generalizable to other settings. However, because the study findings are context-dependent, they may not be transferable beyond the population from which they were drawn. For example, this study investigated arts education partnerships in urban areas, and the findings presented here may not apply to rural areas, where there are fewer artists and arts organization available. Readers will have to determine how similar or different their conditions are compared to those described in this study. 


\section{Summary of Chapter}

This chapter discussed the study research design and the strategies for collecting and analyzing data. Table 7 summarizes these methods, showing how the research questions were operationalized, how the data was analyzed, and the procedures adopted to strengthen the validity of the study. 
Table 7

Summary of Research Methods

\begin{tabular}{|c|c|c|}
\hline Research Questions & Data Collected & Data Analysis \\
\hline $\begin{array}{l}\text { Overarching question } \\
\text { (Q1) } \\
\text { How did the school } \\
\text { and arts organization } \\
\text { administrative staff, } \\
\text { classroom teachers, } \\
\text { and teaching artists } \\
\text { describe their } \\
\text { experiences working } \\
\text { within an arts } \\
\text { partnership? } \\
\text { Q1-A } \\
\text { What benefits did the } \\
\text { various institutional } \\
\text { actors listed above } \\
\text { derive from the } \\
\text { partnership? } \\
\text { Q1-B } \\
\text { What burdens and } \\
\text { challenges did they } \\
\text { face when they were } \\
\text { involved in the } \\
\text { partnership? } \\
\text { Q1-C } \\
\text { What strategies did } \\
\text { they utilize to } \\
\text { navigate these issues? }\end{array}$ & $\begin{array}{l}\text { Observational notes } \\
\text { (Q1-1A-1B-1C) } \\
\text { Individual and group interviews } \\
\text { Transcripts } \\
\text { (Q1-1 A-1B-1C) } \\
\text { Other documents: } \\
\text { - General information about the } \\
\text { schools and arts organizations } \\
\text { retrieved from the Internet } \\
\text { (Q1-A, B \& C) } \\
\text { - Schools SARCs (Q1-A\&B) } \\
\text { Teaching artists' schedules at } \\
\text { each school site (Q1-B\&C) } \\
\text { Orchard's residency's email } \\
\text { correspondence between TA } \\
\text { and teachers (Q1-B\&C) } \\
\text { Orchard residency's planning } \\
\text { meetings Notes (Q1-B\&C) } \\
\text { - Center for the Arts Teaching } \\
\text { Artist job posting } \\
\text { (Q1-B) } \\
\text { Teaching artists contracts } \\
\text { Photographs (Q1-B) } \\
\text { • Schools buildings (Q1-B) } \\
\text { - Art rooms (Q1-B) } \\
\text { (Q1-B \& C) } \\
\text { (Q1-B) Campus Maps }\end{array}$ & $\begin{array}{l}\text { 1) Thematic coding: } \\
\text { Descriptive analysis of } \\
\text { the participants, schools } \\
\text { sites, and arts } \\
\text { organizations based on } \\
\text { interviews, classroom } \\
\text { observations, and } \\
\text { document review } \\
\text { - Analytic analysis. } \\
\text { Identification of } \\
\text { common and dissimilar } \\
\text { themes across the three } \\
\text { sites } \\
\text { Data managed with } \\
\text { Dedoose software } \\
\text { - } \\
\text { Triangulation: Cross- } \\
\text { check participants' self- } \\
\text { reports with filed notes } \\
\text { and other sources of } \\
\text { data } \\
\text { Peer reviewing } \\
\text { Member Checking } \\
\text { Follow up with e-mails, } \\
\text { phone conversation, } \\
\text { and in-person meetings } \\
\text { to clarify data } \\
\text { interpretation } \\
\text { - }\end{array}$ \\
\hline
\end{tabular}

The table presented a diagram of the connections among questions, data, and analysis, that should help readers better understand how these three categories are integrated. The following chapter presents the findings. 


\section{Chapter 4}

\section{Findings}

\section{Introduction}

The purpose of the study was to investigate arts education practices in elementary schools, specifically when arts programs were provided via a partnership between a school and an arts organization. Three elementary schools, Cypress Elementary, Orchard Elementary, and Shadow Brook Elementary, each of which had a partnership with an arts organization, were selected as research sites. The participants included school administrators, classroom teachers, teaching artists, and arts organizations staff.

This chapter presents the findings of the study and is organized into descriptive and analytic sections. The chapter begins with a contextual overview of 1) the participants, 2) the arts organizations and their teaching artist residency models, and 3) the characteristics of the arts partnership at each school. The presentation continues with a report of the findings that emerged from a detailed analysis of the interviews and observations that were conducted at the research sites as they related to the research questions.

\section{Descriptive Information on the Participants and the Research Sites (Research Question 1)}

Description of participants. One goal of the study was to create a rich description of the arts partnerships. I recruited participants as diverse as possible in order to present the points of view of all the key actors involved in the partnerships, i.e. school staff (teachers and administrators) and arts organization staff (teaching artists and administrators). All the participants had several years of experience in their positions, with most of the classroom teachers having over 10 years of teaching experience. None of the participants 
among the school staff had an art background. The level of experience varied more among the teaching artists, ranging from just a few months to over $30+$ years. Table 8 gives an overview of the position the participants held as well as their backgrounds. 
Table 8

Participants Characteristics: Positions and Backgrounds

\begin{tabular}{|c|c|c|c|c|c|}
\hline \multicolumn{2}{|c|}{ Participants } & Position & $\begin{array}{c}\text { Grade } \\
\text { Taught }\end{array}$ & $\begin{array}{l}\text { Years in } \\
\text { Position }\end{array}$ & Background \\
\hline \multicolumn{6}{|c|}{ Center for the Arts (Serving Orchard and Cypress Elementary) } \\
\hline AO A 1 & Murphy & $\begin{array}{l}\text { Director of } \\
\text { Education }\end{array}$ & & 5 years & Arts and Education \\
\hline AO A 2 & Julie & Executive Director & & 8 years & $\begin{array}{l}\text { Music and History } \\
\text { Master in Non-Profit } \\
\text { Administration }\end{array}$ \\
\hline \multicolumn{6}{|c|}{ Orchard Elementary } \\
\hline 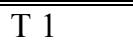 & Jacky & Teacher & 2nd & 30 years & Child Development \\
\hline T 2 & Maggie & Teacher & 2nd & 10 years & Architecture/Business \\
\hline T 2 & Jessie & Teacher & 2nd & 13 years & BA in Environmental Studies \\
\hline T 4 & Deanna & Teacher & 2nd & 25 years & $\begin{array}{l}\text { Social Sciences/Geography } \\
\text { Master in Early Literacy }\end{array}$ \\
\hline TA 1 & Jim & Teaching Artist & & 36 years & $\begin{array}{l}\text { Biology } \\
\text { Master in Special Education } \\
\text { Dance and Theater }\end{array}$ \\
\hline \multicolumn{6}{|c|}{ Cypress Elementary } \\
\hline T 5 & Emily & Teacher & 2nd & 8 years & $\begin{array}{l}\text { BA in Child Behavior } \\
\text { Master in Education }\end{array}$ \\
\hline T 6 & Heidi & Teacher & 2nd & 7 years & \\
\hline T 7 & Karen & Teacher & 2nd & $\begin{array}{l}10+ \\
\text { years }\end{array}$ & Liberal Studies/Spanish \\
\hline T 8 & Susan & Teacher & 2nd & 10 years & $\begin{array}{l}\text { BS in Child and Adolescent } \\
\text { Studies } \\
\text { MS in Curriculum and Instruction }\end{array}$ \\
\hline SA 1 & Beate & Principal & & 4 years & Applied Science; Psychology \\
\hline TA 2 & Florence & Teaching Artist & & 4 years & Graphic Design \\
\hline \multicolumn{6}{|c|}{ Valley Arts Studio (Serving Shadow Brook Elementary) } \\
\hline AO A 3 & Kim & Executive Director & & 16 years & $\begin{array}{l}\text { Professional dancer } \\
\text { School teacher }\end{array}$ \\
\hline $\mathrm{AO} \mathrm{A} 4$ & Mark & Program director & & 2 years & $\begin{array}{l}\text { Music director } \\
\text { Master of Music in Vocal } \\
\text { Performance }\end{array}$ \\
\hline \multicolumn{6}{|c|}{ Shadow Brook Elementary } \\
\hline T 9 & Debbie & Teacher & 2nd & 21 years & No Information (NI) \\
\hline T 10 & Kate & Teacher & $1 \mathrm{st}$ & $5+$ years & $(\mathrm{NI})$ \\
\hline T 11 & Ann & Teacher & 2nd & $(\mathrm{NI})$ & (NI) \\
\hline T 12 & Connie & Teacher & 3rd & $(\mathrm{NI})$ & $(\mathrm{NI})$ \\
\hline T 13 & Vicki & Teacher & 4th & $(\mathrm{NI})$ & (NI) \\
\hline SA 2 & Rosa & Assistant Principal & & 2 years & $\begin{array}{l}\text { BA Spanish Language and } \\
\text { Literature }\end{array}$ \\
\hline TA 3 & Jean & Teaching Artist & & 1 year & Graphic Design \\
\hline TA 4 & Sadie & Teaching Artist & & $\begin{array}{l}\text { A few } \\
\text { months }\end{array}$ & Early Childhood Education \\
\hline
\end{tabular}


Overview of the arts organizations. The Center for the Arts was situated in the San Francisco Bay Area foothills on a large estate comprised of historical buildings, theaters, artist studios, landscaped gardens, and hiking trails. At the heart of the property was an imposing mansion, built in 1912 and reminiscent of Italian Renaissance villas, which housed the offices of the organization. In our interview, Julie, Executive Director at CftA, described how the arts organization was created in the late 1930s. She proudly recalled the story:

Our founding benefactor always invited artists of every discipline to come and live in this historic home with him. He died in 1930, but the notion of having a continual place for artists to come and live was something that he mandated in his will when he died. There was a bequest, a modest amount of money, but the bequest was very powerful. He said that he was leaving the villa and its surrounding grounds to the people of California for promising students. He used the word "students," in art, music, literature and architecture. That's a really important legacy, and so Center for the Arts is holding on to that legacy (Interview Arts Organization Administrator 2).

The artist residency program, one of the oldest in the country, was internationally renowned and welcomed artists in all arts disciplines to live and work on the property for several months. CftA also presented arts exhibitions from contemporary artists, and hosted world-class music, dance, and theater events throughout the year. The education department targeted two audiences: 1) the general public, and 2) public schools. It offered summer camps for children and arts classes for adults throughout the year and provided arts instruction through its Teaching Artist Program (TAP) and on-site performing arts shows for K-12 students during the school day. It also offered professional development opportunities centered on integrated learning practices to K-12 educators. 
By contrast, Valley Arts Studio (VAS) was situated in a modern warehouse, located in a commercial area of a major metropolitan city in Silicon Valley, California. The facility was quite large, housing offices for the permanent staff, two rehearsal studios, a black box theater, a carpenter shop, and several storage rooms for costumes and musical instruments. Valley Arts Studio was — compared to CftA—a young organization. It was founded in 2001 as an after-school, multi-disciplinary arts program at one elementary school and grew rapidly. In 2016-2017, VAS partnered with 125 schools across 14 school districts, providing K-12 students with during-, after- school, and summer programs in the visual and performing arts. Additionally, the arts organization created a "Dream Team" program in 2013 that offered professional training in dance, music, and theater for students in grades 8 to 12 who successfully auditioned. As a part of their training, VAS facilitated the Dream Team students' participation in live performances across the Bay Area.

Comparison of the during-school-hours arts residency models. Both organizations were committed to providing students with quality arts experiences. However, they differed in the ways in which they attempted to achieve this goal. Valley Arts Studio's approach to arts education was to deliver professional arts training in four disciplinesvisual arts, dance, music, and theater. Both Kim, VAS Executive Director, and Mark, VAS Director of Programs, stressed that the instruction provided was aligned with the California Visual and Performing Arts Standards. The arts residencies were organized as a "Rotating Arts Wheel" in which each of the four disciplines was taught one after the other; each rotation lasted six weeks. Sessions were once per week and were typically 30 
minutes long. Schools could elect to participate in the full Wheel and receive instruction in the four art disciplines, or chose only a few disciplines, depending on their needs. Schools could also tailor the content of curricula to some extent: they could opt for standards-aligned instruction, or for a "concentration" curriculum in which each grade focused on one theme. For example, in 2016-2017 at Shadow Brook Elementary, the visual arts residency was a combination of the two: a standards-based curriculum for grades $\mathrm{K}$ to 2 and concentration themes for grades 3 to 5 . These themes were 3-D projects for $3^{\text {rd }}$ grade, textile and green art for $4^{\text {th }}$ grade, and comic books for $5^{\text {th }}$ grade.

VAS also offered a free assembly program that exposed students to opera. The assembly was 45 minutes long and presented a condensed version of an opera (in 20162017, The Barber of Seville), complete with period sets and costumes. Professional artists from the San Francisco Opera, San Francisco Symphony, or Opera San Jose were featured. Furthermore, if schools had a choir or theater residency, students were encouraged to participate in the opera. Mark, Director of Programs, described preparations for an assembly as follows:

What is also unique about our program is that it is interactive. If a school has a choir program, they have the option to come in at the end and sing in the finale chorus with the opera singers. There are roles for the kids to perform as well, speaking roles and non-speaking roles.... On the day of a production, we arrive at the school one hour early, so we can set up the set and get the costumes. The kids also come. There are four artists in the show. Two of the artists will be working in readying the show, the set. The other two will work with the kids that are-in this case, again, it's Barber of Seville, so the acting parts are that of townsfolk playing in a band and a band of policemen that come in at the very end. We'll spend 15, 20 minutes with them, getting them in their little costumes, vests, and props and so forth, and working with them on the lines and running it. Then in the instance where you have the children's chorus come in to sing at the end with the opera singers, what we do is a month or two months before, 
we will send the school and the school's choir director a music teacher, the music, and a recording for them, so they can work with the kids on the music. That way, by the time we arrive, everything is ready to go. We just have to put all the pieces together (Interview Arts Organization Administrator 4).

VAS's emphasis on the performing arts was reflected in its roster. In 2016-2017, the organization employed 48 artists, only four of whom specialized in the visual arts. Teaching artists were paid as contractors and received a new contract each time they began a residency.

Contrary to the "art for art's sake" instruction model of VAS, the Center for the Arts' Teaching Artist Program (TAP) emphasized arts-integrated learning. Based on my interviews with Murphy, Director of Education, and Julie, Executive Director at CftA, the program aimed to develop strong collaborations between classroom teachers and teaching artists, in order to create curricula that supported classroom learning. Through this collaboration, one of the goals was to "build teacher capacity," that is, to provide teachers with the tools and the confidence they needed to integrate arts-based learning into their daily routines. To that end, TAP was designed as a three-year, progressive learning curve, comprised of a 10-12 week residency (a total of 10 one-hour art sessions) each year during the three-year period of the program. Murphy described how the program unfolded:

- During the first year, teaching artists collaborated with the classroom teachers to develop an integrated curriculum that brought together the teaching artists' disciplines with the subjects being taught in the classroom at the time of the residency. The teaching artist (TA) led all ten sessions. 
- Second year: assuming it was the same teaching artist and the residency was scheduled at the same time in the school year as the previous year, the TA led most of the lessons; the classroom teacher taught two lessons.

- Third year: again, assuming it was the same artist teaching the same content at the same time as the previous year, the TA led half of the lessons, and the classroom teachers, the other half.

In 2016-2017, the Center for the Arts partnered with ten elementary schools and employed eight teaching artists as contractors, the majority of whom specialized in performing arts.

Overview of the school sites and the arts partnerships. The elementary schools chosen for the study, Cypress Elementary, Orchard Elementary, and Shadow Brook Elementary, were situated in urban areas. The majority of the students at Cypress and Shadow Brook were English language learners (ELL) and socioeconomically disadvantaged. In contrast, Orchard was located in a wealthier area, had a majority of Caucasian students, and less than $10 \%$ of students were ELL. Cypress and Orchard belonged to the same school district and partnered with the Center for the Arts (CftA) whereas Shadow Brook Elementary partnered with Valley Arts Studio (VAS).

Cypress Elementary. The CftA's Teaching Artist Program (TAP) began at Cypress Elementary in 2013, when it was chosen to pilot the program. During the first year, students from Transitional Kindergarten (TK) through $5^{\text {th }}$ grade participated. Murphy, Director of Education at CftA, explained that the goals for the pilot were to work with teachers around the Common Core instructional shifts in writing, with a focus on project- 
based learning pedagogies. The artist residencies comprised a variety of arts forms, including music, visual arts, storytelling, and culinary arts. Beate, the school principal, enthusiastically recalled how the partnership started:

All of a sudden, we had this program possibly happening. We met with them [CftA], and it started at Cypress before it became a district-wide program...every grade level had a resident artist, so from our TK-Kinders through our fifth grade. Then we had a culminating activity, where every class got to demonstrate what they did, and we had it in the evening. It was a two-hour event. Our TK-Kinders did puppetry. Our fourth- and fifth-graders did culinary arts, so they were actually cooking things that were growing in our garden, and they served all the adults on campus that evening; it was wonderful (Interview School Administrator 1).

The program's impact on students during the pilot year was evaluated by administering pre-residency and post-residency writing tests to all students. The results showed that students had made significant improvements; these results were reported in an article entitled Common Core Standards Can Revive Arts Education in the San Jose Mercury News (July 23, 2013):

The results of a pre- and post- writing assessment administered in 2013 were remarkable. The modified lesson plans shifted approximately $26 \%$ of the students out of below-proficient to proficient or above level with gains in the above-proficient performance level at an average of $8 \%$ per grade level.

According to Murphy, Program Director, and Julie, Executive Director, the district superintendent recognized the value of the program and decided to bring the CftA's Teaching Artist Program to all its elementary schools. One grade level (2nd grade) was selected to be the recipient of the program. Since the pilot year, Cypress has welcomed diverse artist residents almost every year. 
In 2016-2017, the resident artist, Florence, was a visual arts artist who integrated visual arts with science. In addition to working as a teaching artist, she exhibited her personal work, which centered on environment and water conservation, at local museums and venues. At the time of my observations, Florence was teaching a poster-making project about water conservation. I observed her over a period of four weeks and was able to see the project to its completion. Using student-centered and design thinking approaches, Florence had her $2^{\text {nd }}$ graders 1) think of ways in which they can protect the environment and conserve water, 2) sketch their ideas, 3) make a paper collage of their best idea, and 4) use an iPad app to create a digital version of the poster, allowing them to experiment with basic graphic design elements such as composition, contrast, and lettering. Once the students were finished, Florence had each poster professionally printed. Figure 1 shows the main steps of the project. 


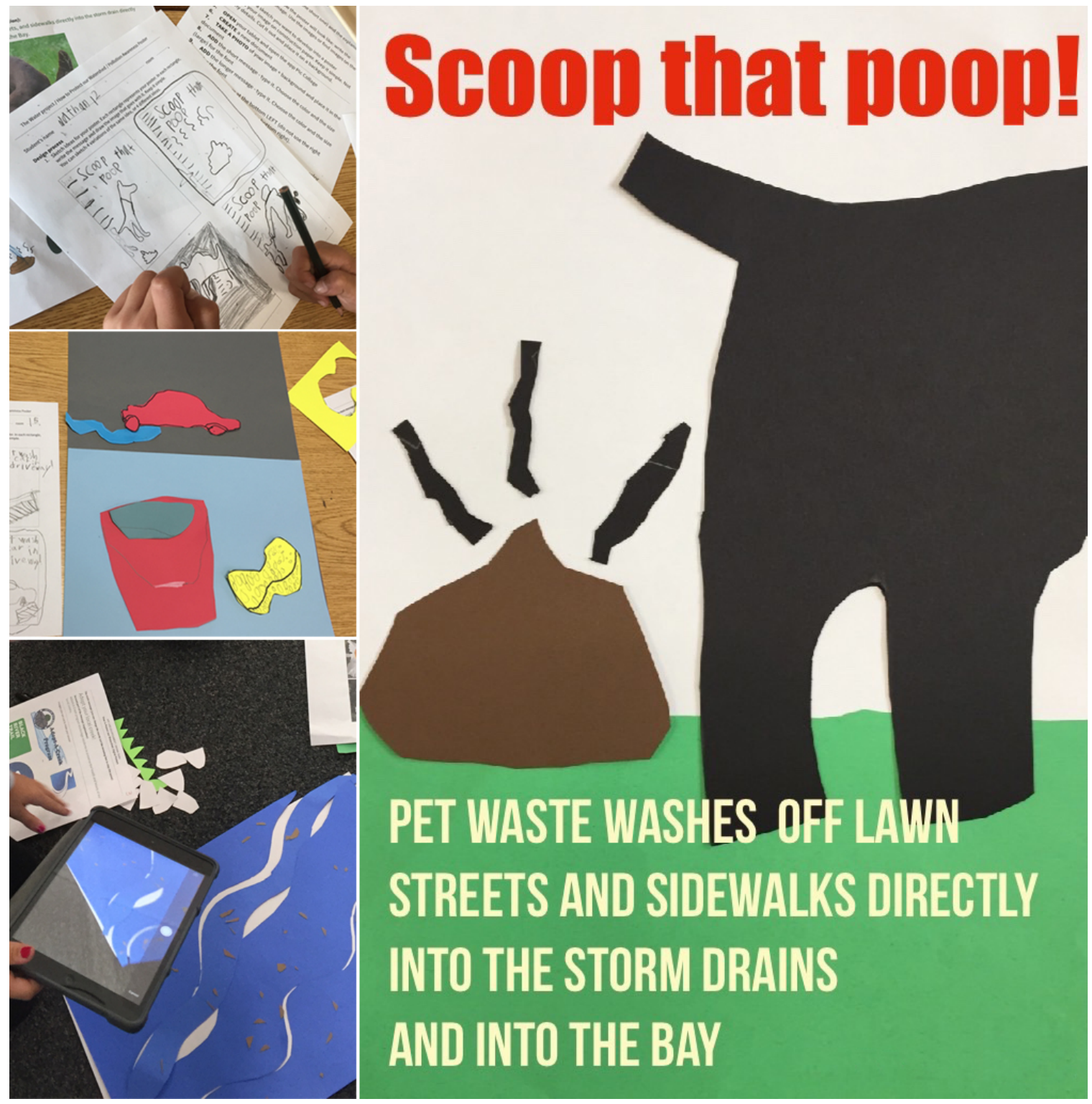

Figure 1. The poster project steps. Top left: sketching ideas; center left: making the paper collage; bottom left: working on the layout and lettering with an iPad app; right: example of a finished poster.

Orchard Elementary. The partnership between Orchard Elementary and the Center for the Arts was four years old. The teaching artist, Jim, was a storyteller and drama teacher; he returned to the school each year. His work at Orchard centered on developing students' awareness of their bodies and feelings through stretching and breathing 
routines, and through acting out scenes from books or academic sources. On the day I observed, which was the last day of the residency, Jim began the session with warm-up exercises. Students were seated in a circle and copied all the movements and poses that he demonstrated and explained. Then, the teachers took over and led the students to act out shapes and tableaux illustrating Language Arts vocabulary words or science vocabulary words relevant to the unit about plants they were studying. Jim explained how he worked with students:

A shape is any position you put your body in. What a tableau is, is it's something that we use in theater sometimes. It's a photograph of a scene where it's not only the people in the scene, but the objects that are important. A tableau is a frozen moment of a story where bodies are representational of things in that scene... We worked at one-point with the story Where the Wild Things Are. In that book a really essential scene is that the boy, Max, goes into his bedroom, and it's a regular bedroom. Then it transforms into a wild place. From that he then launches to the world where the wild things are.

We look at the picture from the book first as an artist. How did the person do shading, how did they do perspective? What information is in there? We look at it that way. Then we look at it for...fact, what's going on in this picture. Then the kids, using their bodies, make that picture from the book. There will be three kids or five kids making the bed, which is a headboard, a footboard, that's shadows, that's pillows. Each child will have one part of that to make. They have to develop that together (Interview Teaching Artist 1).

Shadow Brook Elementary. Shadow Brook's partnership with Valley Arts Studio (VAS) was also a district-funded initiative, and had been running for eight years. VAS served students from grade TK to $5^{\text {th }}$ grade, as well as the students in the County Special Needs classrooms. During the first six years, only three arts disciplines were taught through the arts partnership: dance, music, and theater. In 2016, the school added a visual 
arts residency and required that the visual arts lessons be lengthened: 45 minutes rather than the regular length of 30 minutes.

Jean taught the first visual arts residency at Shadow Brook in the spring of 2016. She came back to the school in the fall of 2016 to teach the second residency, which I observed. However, due to a personal conflict, she needed to leave school early, and Sadie, another VAS teaching artist, joined her in the residency and replaced Jean for the last art period of each day.

Jean had a full schedule: 22 classes per week, and most classes were scheduled backto-back. She taught five art periods on Monday, Wednesday and Thursday, four periods on Tuesday and three periods on Friday, which was a minimum day. Each art period was a different grade and a different art project. Table 9 shows Jean's lesson schedule on the two days I observed.

Table 9

Visual Arts Schedule Illustrating Diversity of Lessons

\begin{tabular}{|c|c|c|c|}
\hline $\begin{array}{c}\text { Art } \\
\text { Periods }\end{array}$ & Wednesday & Thursday & $\begin{array}{c}\text { Teaching } \\
\text { Artist }\end{array}$ \\
\hline $9: 15-10: 00$ & $\begin{array}{l}4^{\text {th }} \text { grade } \\
\text { Weaving } \\
\text { Yarn }\end{array}$ & $\begin{array}{c}\text { Transitional Kindergarten (TK) } \\
\text { Crazy Hair } \\
\text { Drawing/Collage }\end{array}$ & Jean \\
\hline $10: 00-10: 20$ & \multicolumn{3}{|c|}{ Recess } \\
\hline $10: 20-11: 05$ & $\begin{array}{c}1^{\text {st }} \text { grade } \\
\text { Matisse-inspired Still life } \\
\text { Pastels/Collage }\end{array}$ & $\begin{array}{c}\text { Kindergarten } \\
\text { Klee-inspired shapes } \\
\text { Watercolor }\end{array}$ & Jean \\
\hline 11:05-11:50 & $\begin{array}{c}3^{\text {rd }} \text { grade } \\
3-\mathrm{D} \text { houses } \\
\text { Recycled materials }\end{array}$ & $\begin{array}{c}3^{\text {rd }} \text { grade } \\
3-\mathrm{D} \text { houses } \\
\text { Recycled materials }\end{array}$ & Jean \\
\hline $12: 20-12: 45$ & \multicolumn{3}{|c|}{ Lunch } \\
\hline $12: 45-1: 30$ & $\begin{array}{c}2^{\text {nd }} \text { grade } \\
\text { Monster faces } \\
\text { Pastels and watercolor }\end{array}$ & $\begin{array}{c}1^{\text {st }} \text { grade } \\
\text { Matisse-inspired Still life } \\
\text { Pastels/Collage }\end{array}$ & Jean \\
\hline $1: 30-2: 15$ & $\begin{array}{l}\text { Special Needs classroom } \\
\text { (4 classes grouped together) }\end{array}$ & $\begin{array}{l}4^{\text {th }} \text { grade } \\
\text { Weaving }\end{array}$ & Sadie \\
\hline
\end{tabular}


In contrast to Florence's art projects, which required several sessions to be completed, Jean taught short projects that were finished in one or two sessions. On the days I observed, $1^{\text {st }}, 2^{\text {nd }}$, and $3^{\text {rd }}$ grade students were finishing projects they had started the week before. $4^{\text {th }}$ graders were learning weaving techniques; they wove yarn around a paper cup, into which they had first cut evenly-spaced slits. The project was meant to be a one-day lesson; although the cup was small, many students took their projects home unfinished.

Figure 2 shows two examples of Jean's curriculum.
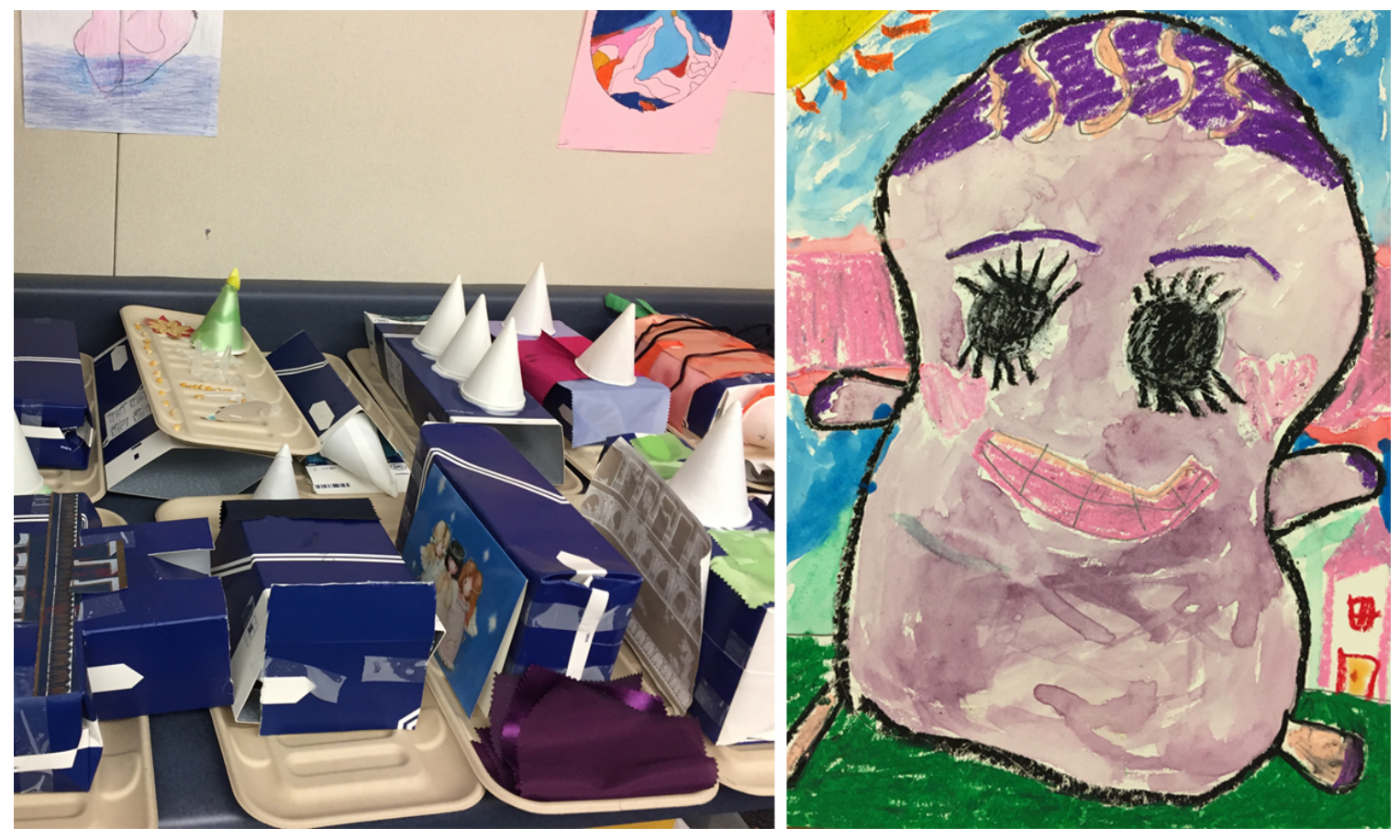

Figure 2: Two examples of Jean's curriculum. Left: $3^{\text {rd }}$ Gr. 3-D houses made out of recycled materials. Right: 2nd Gr. watercolor monsters' faces using pastel-resist techniques.

Description of the school campuses and arts spaces. All three campuses were clean, and gave an impression of neatness, particularly at Shadow Brook, which had undergone a complete renovation in recent years, and at Cypress, 
where the hallways and landscaping were new. The classroom buildings at Orchard and Cypress, although in good repair, appeared to be older. The school office at Cypress was very small and crowded; there was little space to walk between the office desks. In comparison, the office at Shadow Brook was a wideopen space that gave a sense of airiness. On the wall next to the entrance door hung a paper collage mural created by Jean during her first residency, which consisted of a 3"x 3" self-portrait of each of her students, neatly set next to each other. In the middle of the mural, contrasting from a black background, Jean's colorful lettering spelled "It is ok to be different." Figure 3 shows a detail of the mural. All three campuses were enclosed by fences and followed the same layout. The school office, teacher workroom, library, and cafeteria were closest to the street; just behind them were long aisles of classroom buildings with outdoor hallways. 


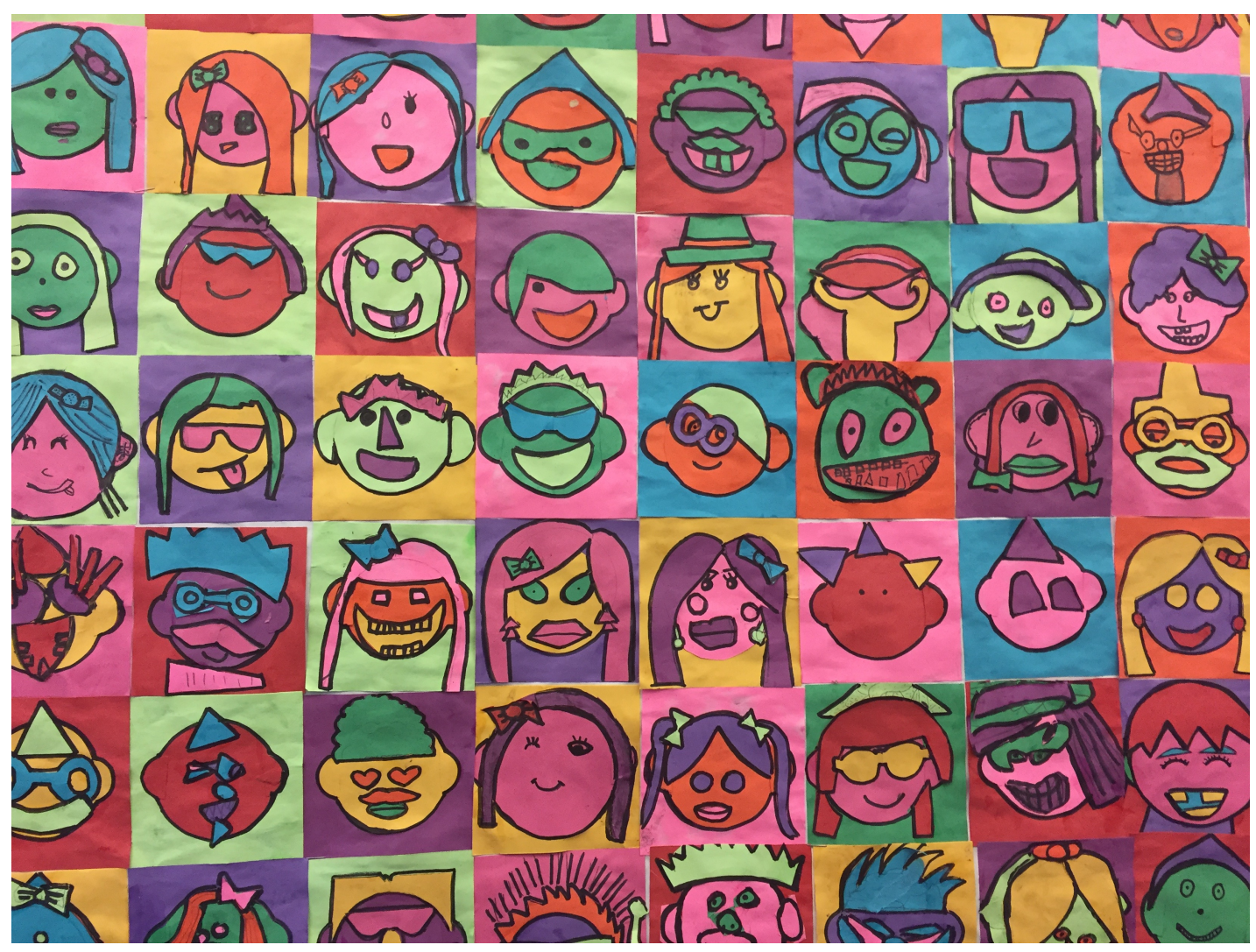

Figure 3: Detail of the paper collage mural hanging in the school office.

There was no specific space to teach art at any of the three schools. The teaching artists were given multi-use classrooms that were utilized during school for other activities such as Physical Education (PE) or for afterschool programs. At Orchard and Cypress, the "art rooms" were rectangular, with bare walls, making these rooms seem as though they did not belong to anyone, or that they were storage spaces. Cypress's "art room" had some small shelves with basic school supplies (i.e. pencils, scissors, and glue) and a few books along one wall, which gave more the sense of being a classroom. There were also PE materials in one corner of the room. The student tables and chairs, and teacher's desk, were old and mismatched. The classroom was located near an open field, at the far end of one of the classroom aisles; it felt remote from the rest of the campus. 


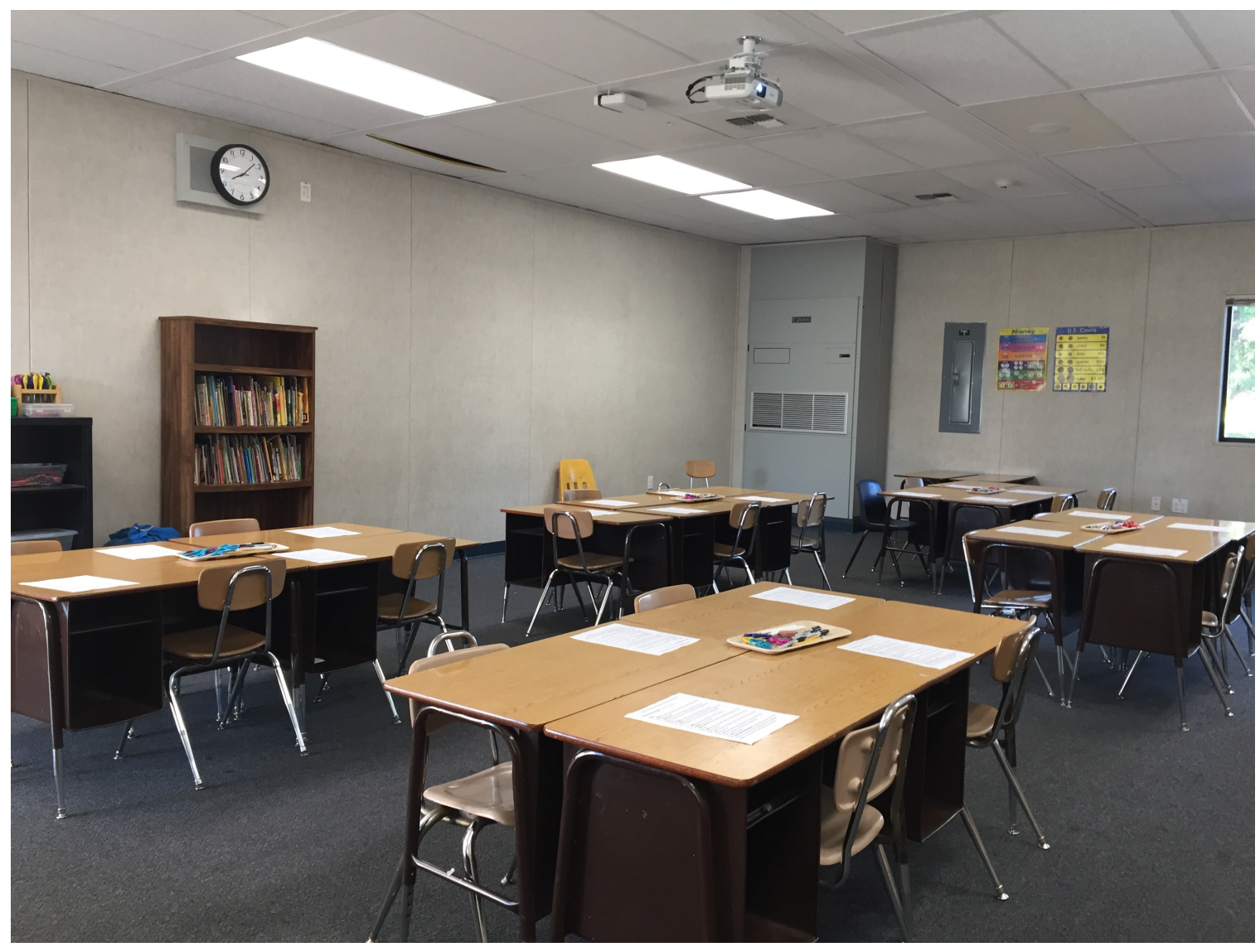

Figure 4. The art room at Cypress Elementary. Some days, Florence, the visual artist resident, kept the desks as they were arranged when she got in the room - in this instance, the students were to sketch ideas for a poster campaign on water conservation-whereas on other days, she pushed all the desks along the walls to create an open space for students to work on the floor.

At Orchard, the "art room" had no desks and felt disorganized. A great deal of miscellaneous furniture and materials were arrayed along the walls, freeing a large space in the center of the room. A large, dark green piece of fabric hung in one corner, which served as the back stage area for Jim's activities. That corner was where students discussed and prepared their tableaux before acting them on the stage, which was the middle of the room. The situation at Orchard was similar to that at Cypress: the location 
of the classroom felt remote, and was a part of a small group of classrooms at the periphery of the campus, again near an open field.

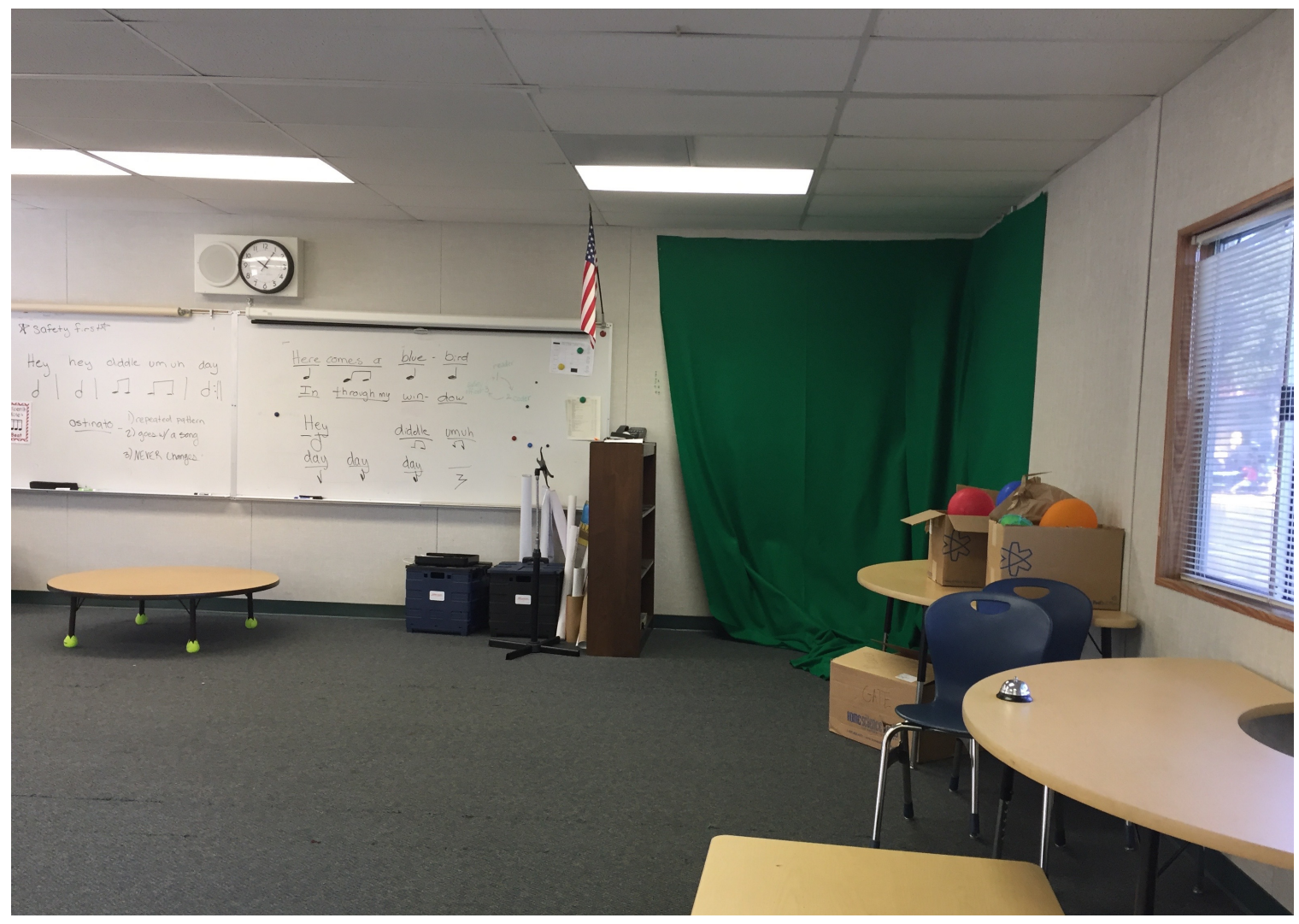

Figure 5. The art room at Orchard Elementary.

At Shadow Brook, the multi-usage room that served as the "art room" was located near the cafeteria and hosted several programs, including Valley Arts Studio's residencies, PlayWorks (a non-profit organization that promoted social and emotional learning through play and team sports), and the afterschool program Kids Learning After School (KLAS). In contrast to the rooms at Orchard and Cypress, this one felt welcoming and looked, to some extent, like an art room. There was artwork displayed on the walls and hanging from the ceiling; however, these works were from the after-school program, not from VAS's visual arts residency. The classroom seemed small; many items were 
stored in the room, including a piano, two adult desks (one for PlayWorks and one for KLAS), a large TV on a cart, PE and play materials, and computers along one wall.

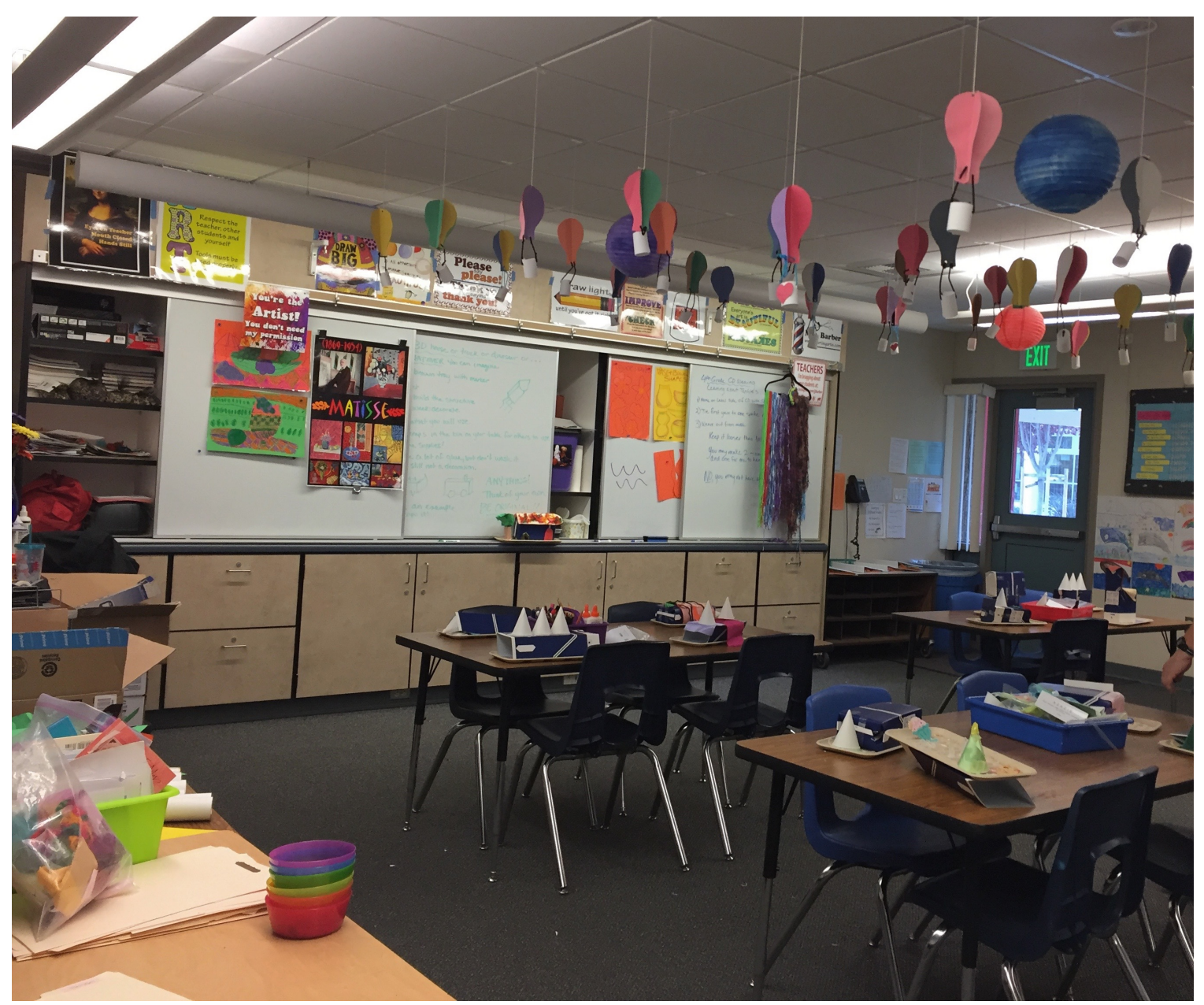

Figure 6. The art room at Shadow Brook Elementary. The classroom was set up for a $3^{\text {rd }}$ grade lesson on 3-D houses made from recycled materials.

\section{Participants Discuss Their Experiences with the Arts Partnerships (Research Question 1- Continued)}

Appreciation for the partnerships. The school principals and classroom teachers I interviewed all expressed their appreciation for the arts partnerships. They used phrases such as "wonderful partnership," "great component," "great benefit to our school," "very 
valuable," "powerful," and "fantastic teachers," to describe how they felt about the arts residencies. Kate, a $1^{\text {st }}$ grade teacher at Shadow Brook, explained further:

I feel it's something that they [the students] really need. They need to get up and wiggle and move their body, and it helps them think differently. When we go there, I feel-I think it's a great component, because they go in, and they learn about music. They look at notes. That's something that they wouldn't necessarily get otherwise. When they go to dance, they're taught a mini routine, and then they learn how to count: five, six, seven, eight. Then they learn about following a routine, following instructions, it's more movement. With every single class, it's a different expectation, and they're exposed to so much more (Interview Teacher 10)

More generally, teachers and principals viewed the arts partnerships as ways of providing an education in the arts that students would not otherwise receive. Kate, who loved art and led an art project each month in her classroom, valued having professional artists coming to the school. She described having these experts in their disciplines as being highly advantageous for her students, as opposed to teachers who, by themselves, might attempt to teach in an art form with which they were unfamiliar. She particularly appreciated the rigor of the visual arts curriculum. She told me that the teaching artist talked to her students about the standards she was covering in her lessons, which allowed Kate to make comparisons with the academic standards she was addressing in her own classroom. Kate also pointed out that many children at her school came from poor families and would not have been exposed to the arts if not for the school arts programs. She said:

A lot of our students don't—-some of them do, but a lot of them don't have opportunities outside of school to go to dance, or to go to music, or any extracurricular activities. Most of them don't have that opportunity, so I really appreciate that they [the artists] come to us, and everybody gets to participate (Interview Teacher 10). 
Appreciation: Arts organizations staff. The teaching artists and arts organizations staff also felt very positive about the partnerships in which they were involved; their comments communicated enthusiasm, passion, and dedication to their work. Mark, Director of Programs at VAS, described his first experience teaching children as lifechanging. He elaborated:

I started to work with kids that are from very underprivileged families that are very hurt by the economic downturn that has happened to the middle and lower class over the last 15, 20 years. It was quite shocking and eyeopening for me. To be able to reach a kid as someone who had more of a privileged upbringing than those, and to be able to connect with them and to give them music, and to connect with them, to me, was an experience that I never thought I would have. It was foreign to me. When I had it, it was like having a fix on a drug. I knew immediately that I wanted to pursue education (Interview Arts Organization Administrator 4).

Florence, the resident artist at Cypress, spoke about her job as a teaching artist with similar enthusiasm. Before working for the Center for the Arts, she taught art for many years as a volunteer in her children's classrooms. She expressed her excitement about being asked to develop and teach arts integration projects when she started working with the Center for the Arts:

That was just like I saw the light. I was like, "This is awesome. I finally found a way to put things more together," because I always had the feeling, when I was teaching in my kids' school, that, yes, I was free to do whatever per week, but it was still kind of not in the program. Teachers were not participating much. It was a lot of good experience, but it was still, somehow, not—yeah, meshed together (Interview Teaching Artist 2).

She continued to explain what arts integration meant to her and how her approach to teaching the visual arts was rooted in her background as a graphic designer. There was a fundamental difference between teaching traditional fine arts, which focused on developing artistic skills in order to produce a work of art, and teaching design, which 
centered on the processes involved to create this artwork. It was important to make this distinction in the context of the school environment, where most teachers did not have any training in the arts. Both teachers and students could learn design and feel successful, thus gaining self-confidence in their abilities to teach and to make art. Moreover, this teaching method encouraged students to develop ideas than were their own rather than being directed by the teachers, an approach that supported the Common Core shift toward deeper learning, critical thinking and analysis. She explained:

"Design is a process and design is a possibility to really take a path and go from $\mathrm{A}$ to $\mathrm{Z}$ and anybody can do that. It's a process you can definitely learn and you do not need to have sketched for ten years to do this. I think that's why it's very important for the teachers because they can effectively grab that and say, "Oh, I can do this." That's exactly what it is. It is not like this super knowledge where it's like-no; it's design and designthat's why I more and more I like to talk about that and to make the kids also understand that the sketches, for example, are very important. More and more I have those sheets and I want them to keep them to look at them to choose, to make choices. They [the teachers] will not choose for the students and they see that and it's part of the whole thinking process. Common Core is all about that, so I think it's very important (Interview Teaching Artist 2).

Jim, the storyteller-teaching artist at Orchard Elementary, expressed the same passion for his work. Using the folk tale of Johnny Appleseed, "who went places and planted trees all over," as a metaphor, he described his role as an educator as one of planting seeds without having any "clue of which ones mattered." This was his primary responsibility as a teacher. Expecting that students would "get what we want them to get" seemed pretentious to him. He elaborated:

"We haven't a clue what they get. I think we plant seeds, and the ones that fall into fertile soil, they grow. The ones where the soil is not fertile, they wait until the soil is fertile. Some of them never sprout. That's fine. 
We cast as many seeds in the best way that we can. Then we just have faith after that (Interview Teaching Artist 1).

Arts instruction was given low priority. Despite strong support for and interest in the arts residencies, the emphasis given to the arts in the schools was far from equal to the emphasis placed on other academic subjects. Rosa, Principal at Shadow Brook, who spoke about the VAS's residencies, said:

It's important. It's important. I will be honest. It [art] takes a back seat to everything else. We're a science focus school. We would love to be someday a STEM school or a STEAM school. There's a lot of other needs. There's a lot of other priorities (Interview School Administrator 2).

This sentiment was echoed by the teachers. For example, Debbie explained:

We're a science school, so there is heavy pressure on the teachers to have a science focus. In my opinion, no. This isn't a huge arts school. Big, big pressure to be a science school... I think that the Valley Arts Studio [programs] are put in place, check, we do art here at the school. That's just how I feel, and that's okay. That's, honest, 'cuz we have so many other things on our plate, that I think that they can rest assured, rest easy that, yes, we do art here, 'cuz we have Valley Arts Studio here, period (Interview Teacher 9).

The arts programs at Shadow Brook were seen as enrichment; thus, they were considered to be outside of the "regular" curriculum of the school. This was made clear in the school's School Accountability Report Card (SARC), which did not list visual and performing arts as core curriculum areas; indeed, they were not mentioned in the document at all.

At Cypress and Orchard, the resident artist only taught $2^{\text {nd }}$ graders, so not all students had access to the arts programs. Unlike Shadow Brook, both schools' SARCs listed visual and performing arts as core curriculum areas, and the second grade arts partnership with the Center for the Arts (CftA) was noted under the "Textbook and Instructional 
Materials" rubric. It was interesting to note that Cypress, with its own monies, funded additional CftA's residencies for its $4^{\text {th }}$ and $5^{\text {th }}$ graders, although these programs were not listed in the SARC.

\section{Participants Describe Benefits (Research Question 1A)}

Positive impact on students. Unanimously, the participants reported that the arts partnerships had a positive impact on the children. At Shadow Brook, the teachers and the principal declared that the students "loved and enjoyed" the arts rotations, and that they gave the children a sense of "feeling accomplished" when they left the art classes.

They saw the VAS arts programs as a way for students to express themselves, to use their imaginations, and to be creative. Debbie said:

It's a wonderful opportunity for all of these children to be successful and happy. The children who have behaviors, the children who are struggling readers, the children - oh, it's a break to just be creative and successful. I know that's a beautiful time that's going to benefit me and the children, because when they come back, they're feeling good. Sure, that translates to other academics (Interview Teacher 9).

Rosa, the principal, specifically commented on Jean's residency. To her, the visual arts allowed the students to feel like artists since they produced their own art, and gave them the ability to better understand artists' works. She said:

I think it's a very positive impact. I think specifically with the visual arts rotation, it gives kids an opportunity to do art, to experience art, to see themselves as artists. Like I said, I think it could be just a moment, a different experience for our students. I think it's very valuable. I hope that they walk away with an appreciation for art and with more knowledge around visual arts concepts and the art that's around us. When they go to a museum, they have a little bit more background on where they are (Interview School Administrator 2). 
For Karen, a teacher at Cypress, which partners with CftA, the visual arts residency

helped children build self-confidence. She elaborated:

I saw a confidence come out of certain students because of that, where academically maybe they struggle...they felt proud of the work that they were doing and they were - it was a way for them to really shine and just be so excited, especially the watercolor. I think a lot of them when they saw that project to start with, they're like, "How am I gonna make that as a watercolor?" When they were done with those, it was like, "Oh, my god. Look what I did." They were so proud of themselves. I can pick a few students in my head who it just brought this light to them and it's like something that they can really feel comfortable and proud of at school when they don't always feel that way in everything that we do (Interview Teacher 7).

Susan, also a teacher at Cypress, added that the art lessons encouraged students to think about their work and to become aware of the processes that are involved in creating a work of art. She explained:

I think it teaches a process, too, like the process of how to take an idea and how to carry that out of - exploring those ideas at first with their sketches and then picking something and then going forward and then once they have that product or whatever - especially with that poster that they didlike changing it and changing their perspective a little bit, so kind of a process of how to take one idea to the end (Interview Teacher 8).

For Florence, the teaching artist at Cypress, connecting students with the world outside the school was essential to her lessons; she hoped her lessons would prompt the students to think about and care for the environment in which they lived:

The unit I develop is really linked to where we live. I think the kids are sensitive to that. I show them photos of the bay, photos of Pacific Ocean, the watershed where we live, the trash in the creeks and stuff, and it's where they live. It's them. It's their community. For that, I think - because they need a sense of space, too. All of these kids in underserved communities, they don't have much. They need a relationship with what is around. They are, sometimes, a little bit lost. The sense of place is very, very important. I try to develop that very much. I think it's empowering, I believe. 
Also, it may give them the-I hope that it plants the seeds of something that will go beyond that, like to say to take care of where we are because it's so important. Maybe a little spark and then, "Oh, yeah, I can participate to clean up with my mom and my dad." A sense of almost citizenship, right? It's not political. It's just a "be there and connect," right? (Interview Teaching Artist 2).

This aspect of Florence's lessons was appreciated by the teachers, who recognized the value of helping students better understand their communities at large and their surrounding environments. As stated by Karen:

I really like the community focus that this unit has because it really gets them to think outside of the classroom and even the school community. It really gets them to think about the Bay Area. They learned a ton about where we live through all of those lessons. They didn't necessarily understand how we can affect the Bay living as far away from it as we do and so I think it just brought up a ton of things about just themselves even, which is wonderful learning. My favorite part (Interview Teacher 7).

Opportunities to learn from mistakes. Both Jean, TA at Shadow Brook and Jim, TA at Orchard, spoke about their residencies as being opportunities for the children to make mistakes and to learn from them. Jim said:

What's nice about the arts is that it doesn't have a single correct answer. What makes it successful is if you tried something new, that is, successful. If the picture is pretty, it really doesn't matter. If a dance piece is elegant or eloquent, it really doesn't matter. What matters is that you try something new and you figure it out (Interview Teaching Artist 1).

Calming effect of the arts. Teachers at Orchard reported that Jim's residency had a positive impact on their students. They described the calming effect his silent activities (breathing, yoga poses, shapes and tableaux) had on the students as individuals and as a group. They discussed the challenges children had to overcome when they acted in largegroup tableaux, which required them to make decisions together about the scene they 
were going to act and to accept the role each student was given by the group. They

underlined the benefits of doing such work, through which children learned more about themselves and were able to understand their behaviors better. All four teachers stressed the importance of giving students the opportunity to learn these skills. Jackie explained:

That was really, the kids struggled with that [acting tableaux] tremendously when we were in larger groups. They almost imploded, at least in my group, pouting and fighting, and, "I'm not going to." "I can't." Just that experience and reflecting back on that, how did that go, I think that will bring forward that it's that larger teamwork thing, which is really hard, when they're not told exactly what to be or what to do. Can we work this out? I think that is continuing. That's a life skill that needs to continue to be practiced... Look at your person, and don't say anything, but do something. That's an important skillset 'cuz they tend to, all of the talking all the time, and really ineffective, often. Too much talking, not enough thinking; two of these, one of these, and just really working on just using their bodies. You could feel it in the room. You can feel the positive calming effect, and that they can feel the unity. They can feel the discord, too, and they can talk about the difference (Interview Teacher 1).

Stand-alone arts instruction: Low impact for classroom teachers. The arts

partnership at Shadow Brook appeared to have limited impact on the teachers beyond their appreciation for the arts programs- - "We love the diversity of the six-week rotations," said Debbie — and beyond their respect for the teaching artists' knowledge and expertise in the arts. This was clearly stated by Debbie:

They're very knowledgeable teachers. They don't just, “This is a piece of art you will make today." They always give us a lot of background information, always, whether it's music, dance, visual arts. Always, they do. The children are- they learn quite a bit (Interview Teacher 9).

The teachers saw the arts residencies curricula as completely separate from their own. Debbie told me that she sometimes took pictures of Jean's art projects, so she could try the projects in class. However, when I asked her if observing the teaching artists' 
activities inspired her to do things differently in her class, she confided, "I have to be honest no, I don’t do anything differently.” She added:

In my opinion, there's very little follow through. When we come back to the room, our schedule is jam packed with science, math, so we don'tthere's no collaboration, "Oh, I'll follow through with coming back and doing this project." We don't have the time. We could be making more time, maybe, but it's very difficult. Our day is very tight. No collaboration or partnership, but it seems to work really well (Interview Teacher 9).

Kate expressed the same attitude. She was "so thankful to have programs like Valley Arts Studio that enriched her students' lives," but she strongly emphasized that her goal was to teach her students to read proficiently. She said:

Because a lot of our students don't come prepared to school, and don't have the skills, don't have the support at home that will make them successful, even just walking into kindergarten. Really, my effort in the classroom is to try to give them a well-rounded education, but my main focus is you gotta read, kid. I just got you-I gotta get you reading. If I can do that, then everything else will fall into place. My main focus is: you gotta read. I gotta teach you how to read (Interview Teacher 10).

In her efforts to provide her students with a "well-rounded education", Kate did an art project in her classroom every month, which she loosely connected to writing. However, she considered the visual arts activity attached to writing not as an instructional tool to teach her student to write, but rather as recompense and as an incentive for students to finish their writing assignments. She explained:

In my class, every month they [the students] have an art project that's connected to some sort of writing, and then that's - they love that. They're ready for any - any project, because they know they're going to be displayed, and they have - and it motivates them to write, because they know like, "If I produce this amazing writing, when I'm done, then I get to express myself in a different form" (Interview Teacher 10). 
Arts integration: Mixed impact for classroom teachers. In contrast, the arts

residencies at Cypress and Orchard affected the teachers and caused them to reflect on their teaching practices. At Cypress, the teachers discussed Florence's method of teaching art. They highlighted thinking processes that were inherent to art-making, and that could be used with classroom work. Heidi made a parallel between Florence's poster-making project steps and the process of writing. She said:

We do that with writing. I think for a lot of - it's hard to get seven and eight-year-olds to be like, "Take that idea and refine it, edit it, draw it out a little bit more," for writing and then go through this long process of taking one piece to a final product. That's something really hard for them, so having a basis of "I did that with artwork before," or "I went from feeling like I don't know how to do that to this final product," that was really special to them. You [Florence] can kind of refer back to that, too and I know-I wish you could see, but I think there are a lot of ways that they use maybe similar processes in class (Interview Teacher 6).

During the group interview, the teachers discussed at length how they could integrate

Florence's projects into their instruction. Susan, who did not see herself as an artist, said:

I feel like I'm not an artist myself and I think that's a lot of the-for me, I don't do art 'cuz I'm like, "Well, I don't know what to do. I don't know how to teach that," but I feel like you [Florence] present it [visual arts] in a way it's like, "Oh, I could totally do that. I know how to teach that now." I know how to bring in art into a lesson and teach them how to be artists and show they're learning as an artist, but also as, "This is what I know about what I learned in that content" (Interview Teacher 8).

Heidi continued:

I think that through this residency, it helps me see not just how I could use it [art] - 'cuz a lot of times I felt like I do art around a holiday project; something that is not maybe as meaningful of how to include it as part of the learning. I think that that's what this helps me see, is they [the students] better understand the area around them because you had them pay attention to the lines and the shapes and how water travels. You [Florence] did that through the art and the way they had to represent what they saw. Then they're better able to maybe retell that information. I think 
that's the piece with Common Core that I am-it would be a goal of mine to include more - is that it's - how will it be a part of their discovery and learning versus just and end product? (Interview Teacher 6).

The impact of the CftA's TAP program on the teachers was evident at Orchard, where the teachers and the teaching artist had been working together for four years at the time of the study. During those years, a strong relationship developed between the teaching artist and the teachers, and the TA shared equally in the tasks and responsibilities of the residency; they collaborated to create the content of the lessons and to co-teach them. The trust that the teachers placed in Jim, the teaching artist, had encouraged them to step out of their comfort zones as observers to, progressively, take the lead on a few lessons. As they spoke about their experiences teaching in front of Jim, they said that they felt "nervous," "anxious," and "intimidated", but they also felt "safe" with him. Jackie elaborated on these feelings:

I feel safe with Jim, but it's made me do things I wouldn't normally [have] done.... The whole idea of having another person in the room changes our teaching. Even though we're teachers, we don't like people watching us teach. We can do whatever we want to with the kids, but we generally don't like that. I don't know why that is, but it is (Interview Teacher 1).

Furthermore, developing the content of the lessons collaboratively with Jim had inspired the teachers to reflect on their own teaching practices and brought them to integrate the techniques they had learned with Jim into their daily practices. Deanna spoke about how she used Jim's exercises every day:

I don't necessarily do the warm-up so much, but I'm constantly using that calming ocean breathing. That's throughout my day. Especially certain students just need that extra breathing time, but there's times in the day where we just get up and move because they need to move, and that leads us into the next activity. Really, it depends on the day (Interview Teacher 4). 
Maggie added that she would continue acting activities, asking students to show their understanding of the classroom readings through tableaux. She said, "This year, after having tried the tableaus of each story, I think I might do that, like a summary, summarize what we have read about this, be it fiction or nonfiction. What is the key details that you wanna show of that text that you write?" (Interview Teacher 2).

\section{Participants Describe Burdens and Challenges (Research Question 1B)}

The burdens and obstacles described by the interviewees differed. Some of these differences depended on the positions and responsibilities of the participants within the arts partnerships. Other differences were found that were specific to the models of instruction, i.e. whether that model was stand-alone arts instruction, or arts integration.

Challenge: Designated art space. Allocating an area for theater, dance, and music instruction was usually an easy task for the schools, as these disciplines only needed a wide-open space; most schools had a multipurpose room that could be used. Visual arts instruction, on the other hand, required a room with tables, a sink, and plenty of space for storing arts materials and students' artwork. In addition, the room had to be available before and after the lessons to prepare and clean up materials. All three schools I studied provided a classroom for the artist residencies. Jim, the storyteller and drama instructor, was satisfied with the multi-usage room he had been given. However, Florence, Sadie, and Jean had to share a room with other users; as a consequence, they were obliged to do all the preparation for their lessons at home and carry the materials (often a significant amount, since they carried basic art materials, such as glues, scissors, pencils, and markers, plus the specific materials they needed for the art project[s] they taught on any 
given day) back and forth from home to school each day. They viewed this as one of the most difficult aspects of their work. Sadie commented:

It's making it strangely difficult. Plus I don't have any storage space in there either 'cause there's so many other places use it. Every day I'm bringing a box of stuff into the room. Especially days when I'm using mixed mediums of - if I'm using pastels and water color and other things at the same time, I have a ton of stuff. I'm carrying it from my car to the room. That's probably been the hardest thing about this (Interview Teaching Artist 4).

At the time of our interview, Sadie was also in residency at another school, and she told a compelling story about the problems she encountered with her room:

There seem to be a lot of miscommunication and not much organization. When I got there the first day, I was told to go to a certain classroom. When I got there, it was a classroom that was completely empty except for tables stacked along the walls and no chairs. I'm not sure what I'm supposed to do with this room. I ended up having to go to the office. They said that this is the room that they used for all kinds of things. I think they had a dance class in there. They had some leadership training for recess leadership or something like that.

Sometimes I'll show up, and it'll be completely empty again. I'll have to search for tables and chairs and things like that. It's a little confusing 'cause it's a very large school. It's a couple stories, and there's a lot of classrooms and a lot of kids. I'm not sure why this one room is being used that way, and it was getting a little frustrating 'cause, I mean, I show up and I have a lot of art stuff to prep. I have a bunch of supplies. I have examples to put up and prints to put up and stuff that I want to write on the board.

I have to show up extra early, so that I can set up tables and chairs and basic stuff like that. There was one point where, I guess, another teacher thought they had that room 'cause I was just about to start a class, and another teacher walked in. She's just like, "Oh, are you finishing up?" I'm like, "No. I'm gonna have this room until 2:45." She said that, "Oh, I talked to so-and-so in the office." I don't remember who. "I was supposed to run a classroom in here." I'm like, "Oh, I'm sorry. I've had this room for a couple of weeks now consistently. I don't really know what to tell you" (Interview Teaching Artist 4). 
At Shadow Brook, Sadie and Jean shared their classroom with two other instructors: the afterschool program coordinator, Ms. Fern, and the PlayWorks coach. Both were often in the room during the teaching artists' lessons. Ms. Fern arrived at noon each day to do administrative work on the teacher's classroom computer, and remained in the room all afternoon. On the second day I observed Jean, Ms. Fern had a meeting with one of her instructors and conducted a rather loud conversation while Jean was teaching. Moreover, Ms. Fern used all the storage space available in the room, as well as the space on the wall, to display artwork from the afterschool program. Jean felt as though she was an intruder. She described her interactions with the after-school program coordinator not without humor:

When I got there, the after-school care lady, Miss Fern, pretty much established that that was her room and she's only allowing us to use it. I worked under that assumption all last year-well, my six-week rotation last year - and then this year, probably until we talked, so maybe three weeks into it, I'm like, oh, I'm at her mercy. Then I'm like, wait a minute. When I calculated out how many hours I'm there, how many hours she's there, it's exactly the same, so that room is as much mine as it is hers. That was interesting. Toward the end [of her residency], I started just taking more liberties. I just took some extra space in the cabinet because I'm like this room is just as much mine as it is hers (Interview Teaching Artist 3).

Florence, the teaching artist at Cypress, told me that the room she was using would be converted into a maker space next year. She worried that she may not have access to the room for her next residency, and that her only option would be teaching in the regular classrooms, carrying her materials from one room to another. She stated she was growing weary of the situation and was considering whether to accept the next residency at that school if she was not assured that she would be given a room. 
Challenge: Hiring visual artists. Kim, Valley Arts Studio Executive Director, and Murphy, CftA Director of Education, agreed that the visual artists worked under conditions that were far from optimal. These circumstances, added to the time required for preparing materials, created significant challenges that few visual artists were willing to undertake. Kim explained further:

There are lots of actors and directors. There are lots of dancers. There are lots of singers. It's a very competitive environment. It's easy for us to find a lot of talent. We audition; we interview thousands of people to choose the right person. There are very few people that interview for visual arts positions. Either they're already in a school, committed to a school, or they don't wanna travel. There are certain restrictions for a visual artist. They've gotta have enough room to actually create their stuff. They have to have the room, the venue. Some schools don't have that. You have to go from room to room with a cart. They don't wanna do that (Interview Arts Organization Administrator 3).

Murphy also described how recruiting visual arts artists that were comfortable with and knowledgeable about arts-integrated learning added another level of difficulty to the hiring process. She said:

I think there's this distinction between the classroom art teacher and someone who is doing teaching artist work in an integrated method or model. It's just different. I look at that very closely when I'm reviewing someone's application and when I'm observing them. I may ask a lot of questions in that interview process around, "Explain to me a lesson that you would do that would teach this principle in English or this principle in science" (Interview Arts Organization Administrator 1).

Challenge: Feelings of isolation among the visual artists. The visual artists I interviewed felt isolated at their schools. They spent nearly all of their time either preparing materials or teaching, so they had no opportunities to socialize with the school staff. During the lunch break, while classroom teachers gathered in the staff room to eat, Florence and Jean stayed in their rooms preparing materials for the next lessons. They did 
not even take time to sit for their lunches. Florence ate a cereal bar and an apple while she cut and sorted out construction paper.

Florence felt alone in her work and spoke wistfully about the possibility of connecting with other teaching artists and being part of a community. She told me about Artists Connect, an event organized by the CftA a few times a year, which aimed to facilitate networking between artists and arts educators. She said:

We should be a family of people or knowing each other, knowing what we do and sharing stuff. Murphy tried to do that, but it isn't reallybecause the Artists Connect- they don't come. You don't see the teaching artists, and I don't know why... You never know who works in the-we don't receive any mail saying, "Hey, this spring, you have dada-da-da-da working here doing that, and it's cool. We have a unit about identity, and we have a unit about water, and we have this, and this is-," we have nothing. It's very-I do feel very isolated (Interview Teaching Artist 2).

In addition to wanting companionship with fellow teaching artists, Florence questioned herself about the curriculum she created. She said, "As an artist, I learned a lot of techniques and stuff, so I'm fine. The integration part, I don't know, I think it kind of comes naturally... I like it and stuff, but will it be good?" She would have liked to meet with other artists to discuss their approaches to arts integration. She explained:

I would love, for example, to be in a room or to have sessions with a group of teaching artists. You give the same subject, and you have to write a curriculum for ten sessions or something and what we come up with, and how do we articulate - how each of us articulates the different things that we need to put in this knowledge - this ensemble of knowledge. I would love that because I feel very isolated — extremely isolated (Interview Teaching Artist 2).

Jean was a graphic designer for more than twenty years. She decided to change careers in order to spend more time with her children. She had been working for Valley 
Arts Studio for a year at the time I interviewed her. Jean had some experience working with children as a Boy Scout camp instructor, but very little with designing a curriculum. She needed help with her lessons, but did not find much support from the other VAS visual artists who, like her, were quite new to their jobs. She said:

I think it was more sharing ideas, like this is what I did. I found this project was really good. I'm always writing down, what did you do? Okay, I'm gonna try that. I'm the only one that - there's four of us-I'm the only one that sent an email and said, "This is my lesson, and I don't know what to do here." Sometimes people give feedback. Most of the time they don't. There's only four of us. I think was, we made superhero masks. I said, "How do you do this? Do you use regular glitter? Is the glitter gonna get in their eyes?" Not very many people replied. I think I got one reply back, and it was from the person who originated the lesson. She's like, "Yeah, don't use regular glitter" (Interview Teaching Artist $3)$.

I met with Jean several times to observe her classes and interview her. Each time, she was stressed and worried about the new curriculum she was asked to teach at Shadow Brook.

The upper grades had chosen concentration themes instead of the regular standardsaligned visual arts curriculum. She was particularly anxious about the $5^{\text {th }}$ grade comic books curriculum. She told me her fears, which she tried to hide with a few laughs:

There is somebody at the office who's the lead art teacher, but she only has one more year of experience than I do. She's the one that comes up with the concentrations. They're all her favorite things to do. Comic books are her favorite. Last night I was on the phone with her saying, "What do I do now?" I said, "I was thinking maybe the last day, they could do one-point perspective and put their cartoon character in the middle." She says, "You haven't done one- point perspective yet?" I thought, "What? I was supposed to have done this? Nobody told me that I was supposed to have done one-point perspective earlier in the session." Now I had nightmares last night. I had a migraine when I woke up this morning, 'cuz I'm so anxious about the comic books. It's not my thing. It's not my forte. I'm not into comic books. I don't like reading them. [Laughter] I don't like drawing anime characters. It's been extremely stressful. For me, maybe a little bit more guidance on the new curriculum 
would have been great. [Laughter] Yeah. Even maybe somebody saying, "Here. Do it like this," because in some of the lessons, I don't need that. If we'd just discuss the California curriculums, you're gonna do tint and shade. You're gonna do facial proportions. I can come up with those myself (Interview Teaching Artist 3).

She continued:

Comic books is just beyond me. I feel like I'm letting the kids down, although the kids seem to be happy. They seem to be enjoying it. The other problem with the comic books is that you have to teach a lot of writing. My husband is an educator. When I came home and told him what I was doing with the comic books, he says, "You're not qualified to teach writing." I'm like, oh, yeah. I guess it is writing, 'cuz they have to come up with a story for their comic books. I had to tell them all about character development and story arc and all of that stuff. That's not my area of expertise (Interview Teaching Artist 3).

Need for feedback. Another aspect of the TAs' isolation was that they received little or no feedback on their lessons or their overall performances as teachers. VAS sent forms to the teachers to evaluate the residencies, with questions such as: how did it go? Did you enjoy this? Were the TAs effective? Did the children grow from this? However, very few teachers returned the forms. Jean told me that not a single teacher at Shadow Brook filled out the survey about her 2016 spring residency, although it was the first time the school has a visual arts rotation. She said:

I did three rotations last year, and the very first rotation, when I had no idea what I was doing, those were the only people that responded to the survey. The second and third rotation, they didn't say anything. I figure most people like to complain more than they do compliment, so if something terrible happened, I'm sure that they would've commented, but they didn't comment (Interview Teaching Artist 3).

Florence also wanted more feedback from the teachers. A few weeks before staring her residency, she e-mailed the teachers detailed information about her lesson plans, including pictures of what the steps would be and how the finished projects would look. 
She hoped the teachers would send her comments and that she could have had a discussion with them about her curriculum, but none of them responded. She explained:

Usually, they don't [give feedback]. I wish, and I always say, "Please, please, please, edit, comment, please," and they don't. They're like, "Oh, that's great." I'm like, "Ah, this is not what it is for." I need also their feedback and stuff. What I do is that, as I am doing it, I change the way I do, of course. It's the way-it's not so much their feedback, but it's the experience that, "Okay." Usually, they are like, "Oh, that's great. That's great. Okay" (Interview Teaching Artist 2).

Challenge: Teachers' participation. Most teaching artists were not credentialed teachers. Per school policy, the classroom teachers had to be present at all times during arts lessons, but there were no explicit directions regarding their responsibilities. The teachers' participation varied greatly, depending on whether arts integration or "art for art's sake" was the goal of the lesson.

Shadow Brook Elementary. At Shadow Brook, where the arts were taught separately from other academic subjects, the teachers did not participate at all. There was very little interaction between the teaching artist and the classroom teachers; sometimes the teachers did not even greet the TA when they entered the room. Most of them sat at the back of the classroom, working on a computer. One of the teachers used the art lesson time to have a conversation with her teacher-intern; another teacher cut cereal boxes into rectangles, completely ignoring the art lesson in progress.

Mark, the VAS director of education, preferred that the teachers stay in the background. He explained:

Valley Arts Studio class time, it's a Valley Arts Studio class. It's the artist, the Valley Arts Studio artist that is running it. There is no symbiosis between the schoolteacher and the Valley Arts Studio artist while a class is happening. 
Most times in my experience, depending upon how well the class has behaved or how well they're doing in general, I'll let the teacher say, "Look, this is 30 minutes for you. If you want to catch up on grading. If you need to send some e-mails, by all means." Unless a kid has a meltdown or has a special needs that I'm not able to give aid or comfort to, then I'll bring the teacher in to help me and assist me (Interview Arts Organization Administrator 4).

Sadie too, liked teachers to keep their distance. She saw herself "giving a break to the teachers" when she taught a lesson, and she appreciated that the teachers gave her free reign to lead the class. She said:

"It takes a little bit of pressure off the teachers too 'cause I'll be in the class. There will be a teacher in the corner able to catch up on things and grade papers while their class has a little bit of a break from that as well.... They're free to do what they want, but I find the majority of them will take a step back. None of them really try to take over the class which I like. 'Cause that was one concern I had is that this is their classroom. I thought they might try to teach alongside me or maybe even try to teach on top. I haven't had that experience, so I'm grateful for that at least. It seems there's a lot of respect there for what I'm doing. There's a mutual thing' (Interview Teaching Artist 4).

Classroom management. The teachers' distant attitudes were a challenge for Jean

when discipline issues arose. She did not have the opportunity to know the children well, due to the short time she spent with them-only six 45-minute sessions. This made it difficult to keep good control of the class. For Jean, some days were harder than others.

She told me this story:

I read a lot on Pinterest. That's how I came up with the whole-I didn't come up with it - I say, "Mona," and they say, "Lisa" to get their attention. My husband, who's in education, is like, "At least you got that." Some people come in and they just don't know what to do at all, so at least I had a little bit of classroom management. Also, since we've talked, I talked to another teacher, who said maybe I should say, "What are your expectations?" because I always thought they didn't wanna be bothered. She said, "No, I would help you out if I knew that you needed the help, but I don't wanna step on your toes." It's a learning thing. I think I might 
need to ask the teachers, "What are you expecting me to do?" "Do I have to manage your class, or can you jump in?" I had a kid crying the other day, and I told the teacher, "He's crying," and she's like, "Your problem." He's your kid! He's in your class. It's not my problem that he's crying (Interview Teaching Artist 3).

The fact that teachers and TAs did not know each other well led to misunderstandings about one another's roles, as Jean described, above. Debbie and Kate, the two Shadow Brook teachers I interviewed, agreed that some classrooms were "very rude and out of control" during arts lessons. Kate said:

The big one [challenge] for everyone, right, is classroom management. I think that would be a-just being clear about expectations at the beginning. I feel the first class, all of them [teaching artists] are really good about teaching them the rules, their expectations. Just gentle reminders at the beginning of each class, I think, would benefit (Interview Teacher 9).

Debbie continued:

That's where my heart really goes out to these Valley Arts Studio teachers, because Kate is pretty strict, too, with behaviors, and so am I, and just - teachers are different. Teachers are different. My heart really goes out to them [the teaching artists] that they have to sometimes spend a chunk of time on those behaviors, and I don't think they should have to. It would be nice if, maybe, the administration or somebody came through and just made it very clear to the teachers and the students, these are the behaviors we expect (Interview Teacher 9).

Orchard and Cypress. The teachers' attitudes and behaviors at these schools were the complete opposite of what I observed at Shadow Brook. There, all the teachers came to art class empty-handed and ready to assist the teaching artist, and there was camaraderie between the teaching artists and the classroom teachers. At Cypress, teachers sat next to the students, either at the tables or on the floor, and paid as much attention as possible to the students who needed help, sending the students to Florence when they were not sure 
how to answer their questions. At Orchard, the teachers smiled as they came into the room; they looked as excited and eager to start the lesson as their students. They sat on the floor with their students and did the warm-up exercises.

Classroom management. Discipline during art lessons did not appear to be an issue at Cypress and Orchard. On a few occasions, I observed a small number of students acting out, but the teachers addressed these students immediately. Nonetheless, Beate, Principal at Cypress, reflecting on her experiences with previous residencies, expressed her concern that that most artist residents had no classroom management training. She explained:

Artists can sometimes be very different thinkers than a teacher...Getting that right person who just knows, who has that - the behavior management. They can handle the children, too, and then they also wanna help the teacher versus someone who's just comin' in and just focused on doin' art with the kids and then not really lookin' at the broader scope of when you're in front of 24 children, you have to be able to manage 24 children. I think that's where the teacher helps the artist, giving them a little bit because artists are different people. They don't teach every day, and teachers are not artists all the time (Interview School Administrator 1).

Challenge: Schedule. All the participants I interviewed reported that creating a schedule that worked for everyone was a difficult task. The VAS arts schedules were often developed long before the residencies took place, frequently during the summer. Problems arose if a school forgot to report the need to adjust the schedule because of a field trip or a minimum week, so it was left to the teaching artist and the VAS director of programs to resolve the issue when the artist was at the school.

Teachers at Shadow Brook did not report having significant problems with the schedule, beside the occasional conflict with a classroom activity. Moreover, since the 
Rotating Arts Wheel, with its four arts rotations, lasted the entire school year, the weekly time for art was included in their classroom schedule. At Cypress, it was a bigger problem for the teachers since their residency lasted only 10 weeks. It changed the daily classroom routines significantly, and they had to devise ways to make up for the classroom learning time that was used by the art sessions. Karen explained her frustrations:

It's true 'cuz I think we've all kinda taken different times of day in the different residencies we've had throughout the years. Different times just feel more comfortable, but I would say we during that time were teaching something else, so that thing just didn't get taught that day. For me, it was like our reading time where we would be reading and so I wasn't as maybe worried about what I was missing out on, but like last year's residency was during my math time and so I was really worried when I would miss out on math. There's that aspect of it, but I loved having it after lunch 'cuz it was kinda like, "Oh, what do I have to do after lunch? Oh, I have art. Goin' to art." For my day, it was kind of nice 'cuz it was a nice thing after lunch (Interview Teacher 7).

Heidi reported that not being able to teach everything that she had planned for the day

was stressful for her, and kept her from enjoying the art time and appreciating Florence's

lessons. She explained:

I would say the unfortunate side of it is that given all that we are expected to teach throughout the year and throughout our day, like all the subjects, it's really hard as a classroom teacher to not view it as like I'm missing that lesson today and I gotta make up for that time somewhere else. I think sometimes, unfortunately, that takes away from thinking like, "But look at this amazing lesson they get to- - you know what I mean? They get to have this art which is missing from so much of our-like I feel like my classroom time or just our school year, so I feel like I'm so grateful for it, but it is sometimes hard in the moment or when I'm planning, being like, "Ah, that's-" it was during math time. "I'm missing that math lesson today." It's hard sometimes to adjust a schedule. I think schedule's the hardest, sometimes. It is just having to reflect and be like, "But look at why we're doing it and what it's providing for them." I will say, to be honest, sometimes it's hard not to view it as a time that's like, "Oh, that 
took away my math time," or "That took away my writing time," but I wish I didn't view it like that 'cuz sometimes it does

(Interview Teacher 6).

Visual art schedule at Shadow Brook Elementary. The tight schedule at Shadow

Brook was a strain for Jean on two levels. First, she found it physically exhausting: from the time she arrived at the school in the morning until the time she left, Jean was busy. She had no time to rest between her lessons, which were concurrent; as one class ended and the students left the room, the next class was already waiting at the door. Sadie commented on Jean's schedule:

You need a little bit of a break. That's insane...Five, ten minutes between. Yeah. That's ideal. Back to back like that, where it's one class leaving another one coming in, no. That won't do. [Laughter] That would be impossible to work with 'cuz not only do you have to clean. You have to prep. Not everyone is learning the same thing, 'cuz you'll have a second grade going into a fifth grade. That's completely different lesson, completely different materials. I mean, the other day she [Jean] was a little frazzled because she's just-yeah. She's a trooper. [Laughter] Yeah. Ideally, definitely would be a little bit of a break. Like in high school, you change classes. You get five minutes to walk between classes. Just five minutes make a huge difference (Interview Teaching Artist 4).

Since Jean could not allow herself or her students one minute of distraction, she had set up a timer on her phone, which she carried in her apron and consulted often. She timed each step of the lesson carefully in order to balance her instruction or demonstration time with student working time and with material set up/clean up.

All these constraints made her lessons very fast-paced, which the teachers disliked, as this had an impact on the students' learning. Kate said:

As she's speaking, and that's where we leave some of the kids behind, because she's going so fast, because she knows she's on a timeline, that the students are-you have to come in, sit down, and just refocus, what are we going to do. The minute you come in, it's go, go, go, go, go, and, 
already, the students are like, "What? What's going on? What's the expectation? What do I need to do?" I think if we had just a little bit of extra time, then it would relieve stress from the instructor as well, and it would give them time to be fully prepared for the next class, and not feel that sense of just feeling rushed (Interview Teacher 10).

In addition, many students at Shadow Brook were English Language Learners and, especially in the lower grades, had difficulties following instructions, as Debbie explained:

Some of our children are non-English speakers, so in the lower grades, like TK, kinder, first, some of that language hasn't developed, and their instructions are so fast. "Come on, my expectations, let's move." They're still trying to play catch up. When I taught kinder, that was a struggle, I'd have to remind them, "You have to slow down or be more patient." That's a high population of our students (Interview Teacher 9).

She also regretted that students sometimes could not finish their project in art class had no other opportunity to finish it in the classroom, due to her need to focus on other subjects:

There's always children that don't finish. They just need more time. Not necessarily 'cause they're talking to their friends. Their brains are just developing differently, and they're not done. Often they'll come back and say, "Can I finish my painting?" "No, we're doing math, and I don't have these materials" (Interview Teacher 9).

Challenge: Continuity within the arts programs. The fact that teaching artists were not permanent employees of the arts organizations created one of the biggest challenges to maintaining consistency and continuity in the arts programs offered through the arts partnerships. As contractors, teaching artists could choose when they worked and how many residencies they took on; some teaching artists were educators only, while others continued their professional careers while they were teaching. Consequently, there was no guarantee that the same artist would renew her/his residency at the same school the 
following year. However, there were artists who returned to the same school for several consecutive years, allowing them to develop relationships with their students and teachers. Debbie, a teacher at Shadow Brook, explained:

What's unfortunate is sometimes we'll have five consecutive years of the same drama teacher, and the children adore them, and they become close, close bond, but then they get moved to another school and we get a new one. It's good and bad (Interview Teacher 9).

Rosa, the school assistant principal, also commented on the pros and cons of this situation:

I feel like in some ways, yes, it's nice to have consistency. They build the relationship with students. They know the students. They can build on what they've done the year before. In that way, yes. Also, depending on what they've developed, what lessons they've developed, it can also become repetitive.

I know for one of the artists, it was doing the same curriculum year after year. Well, if you did the same thing when you were in first grade, and now you're doing it again in fifth grade, you're probably not that excited to go to the Valley Arts Studio rotation, right? I think there's pros and cons (Interview School Administrator 2).

These inconsistencies between residencies were a major issue for Jean in terms of delivering a standards-based art curriculum. She described her difficulties in teaching lessons that were grade-appropriate and standards-aligned to students who had not mastered art standards taught in earlier grades. She explained:

When I was teaching fifth grade, the last thing we did was a one-point perspective, so I basically said this comic book thing is stupid. We're gonna do one-point perspective. I said, okay, remember when you learned foreground, middle ground, background - and they said, we don't remember that. I thought, oh, no, you didn't learn that in third grade, 'cuz I wasn't there when the fifth graders were in third grade. They said no. I'm like, oh, no. This year's third graders didn't learn it because we were doing 3-D. 
In second grade, we teach overlap, so I was showing them all the trees in your one-point perspective overlap, remember when we did that in second grade? They're like, no, you weren't here in second grade. We didn't learn that. If I was able to stick with the same school for five years, then I could teach them everything, and by the time they got to fifth grade, we could refer back to, remember this, or the color, and blah, blah, blah. With the concentration, it messed that all up, because those kids are not getting the basics for third grade (Interview Teaching Artist 3).

Lack of consistency and continuity at Cypress Elementary. From the beginning of the CftA residencies, Cypress usually welcomed a different artist each year. Moreover, the residencies occurred at different times during the school year, sometimes in the spring, sometimes in the fall. This created several difficulties.

First, the progressive learning curve to build teacher capacity could not be maintained. Although teachers were invested and participated in the residencies, they were not able to take the lead for any of the lessons, since the content of those lessons was new each year. In the group interview, the teachers expressed their confusion regarding what their roles and responsibilities should be, even though they were five years into the program. They wished they would get more directions from the CftA staff. Heidi said:

In terms of I would say communication from Center for the Arts, I feel like the last few years - from my perspective - that sometimes we are unclear, as the classroom teacher, on what our role is expected to be throughout the residency because I felt like last year it was kind of sprung on us like-I think they're [the CftA] kind of piecing together the structure of what they would like a three to five year residency to look like, but because we've switched art teachers a few times at our grade level and then they were sort of just developing this as we were piloting it a little bit, too, I think sometimes we were unaware of like are we expected to teach some of it? Are we expected to be in it a little bit more or bein' in front of the class with them? Also, I feel like from the Center for the Arts side, it's been for me a little unclear of are we supposed to come up with the lessons? Are they? Do we teach it ourselves? I don't 
know what you [the CftA] guys think. That was a little unclear for me over the years (Interview Teacher 6).

Murphy, Director of Education at CftA, discussed the situation at Cypress and recognized that there was no solution to this problem as long as schools chose the artist and the art form with which they would like to work. She said:

They switched artists every year. As such, that continuity hasn't been present. As we've asked them to step in and instruct more, it's considerably harder to do that because from one year they've gone from one visual artist, the next year to a musician, and now to a different teaching artist. That's been part of the learning curve, but we still reach out to give those teams choice and autonomy around what they wanna be looking at and what they feel would benefit their profession and their practice to the greatest extent possible (Interview Arts Organization Administrator 1).

The second issue that surfaced was the difficulty of creating content that was connected with the classroom learning at the time of the residency. In some instances, the schools' curricula changed from year to year, and teaching artists had to create a completely new curriculum in a very short time. Murphy told this story:

In the fact that the curriculum is always changing and sometimes it's a new artist, we just had a meeting in December with an artist that's been in the program three or four years. She's worked with this team. It's now her second year and had this idea that maybe she was coming back to do the same thing, and they're just not teaching that this year. All of a sudden, we have 90 minutes to set a schedule and then look at, "Okay, well, you guys aren't doing__" I think it was lifecycles from last year. "We are doing all of this," and I see the artist get a little wide eyed and, "Oh, my god. I have to rewrite all of this. What am I doing?" (Interview Arts Organization Administrator 1).

At other times, matching an artist and his/her art form to the classroom learning was not possible. This occurred on a few occasions at Cypress. Karen explained that the first visual art artist resident taught projects that were not replicable; she felt "like I couldn't 
take that same concept and apply it to something else." Her colleagues discussed another resident, a musician, who taught lessons that were not connected at all to the $2^{\text {nd }}$ grade curriculum. Heidi voiced her frustration at not being able to connect the content of the residency to any of the classroom learning. She said:

Last year it was like if it's not related at all, then it was like, "Well, now I have this totally separate thing we did one day," and I'm like-I'm trying to find a ton of other parts during the week and when can I connect that? (Interview Teacher 6).

Susan continued:

It made the residency and everything else not enjoyable during those lessons because it felt like we had to not only have our resident come to our classroom, but we had to teach what the resident was teaching outside of our time with the resident (Interview Teacher 8).

Finding collaboration time at Orchard Elementary. While Orchard had also adopted new curricula in the four years of its partnership with $\mathrm{CftA}$, consistency did not appear to be the problem that it was at Cypress. The resident artist, Jim, a storyteller and drama teacher, returned every year, and his lessons seemed to be more easily adaptable to all kinds of academic areas. In the group interview, the teachers discussed these curriculum changes and how they had left Jim's program unaffected. Jackie explained:

Every year it's been different as far as what our core stuff has been. Right? We had two years maybe the same, but we had storytelling that first year where they're [the students] actually presenting to another grade levelthose were the fables, and we got rid of fables and went to tall tales and fairytales.

We did that for two years, I think. Now we're in the new program, so he's [Jim] trying to use what we're doing. There's been a core skeleton that's always been the same, as far as the routine, and trying to, every year, get the children to focus on what it means to be in control of their body and how to calm their body, how to recognize their feelings. That's just a universal, I wouldn't even say a thread. It's like a cable, [laughter] that keeps going through (Interview Teacher 1). 
The challenge at Orchard was for both the teachers and the teaching artist to find

planning time in order to develop content for the sessions and to debrief teacher-led sessions. Murphy, who tried to attend all of the teachers-TA planning meetings so she could document these meetings and archive notes, reported that finding time for face-toface meetings was nearly impossible. She said:

It's hard to even find the time for a planning meeting. Their professional development time is extremely limited, their planning time is extremely limited, and the only way to really talk through a lot of these various aspects and set a curriculum and design the curriculum is to have a faceto-face meeting that is not quick. I think finding meeting times is really difficult (Interview Arts Organization Administrator 1).

Jim echoed the same concern:

Because we're not colleagues in the same facility, in the same school, we don't see each other a lot, and we have the amount of time we have for class, and then we begin to add on planning time. That's always problematic because the one resource that schools are most limited by is time, time with the kids and times to collaborate. That's the most precious time, and that's what there's the least of. That's what everybody is competing for in a positive way. If we were colleagues in the same school, then we would have these conversations between classes or over lunch, and it'd be very easy. Then, if we did that, we would be able to dovetail our work more precisely (Interview Teaching Artist 1).

The few joint meetings that occurred during the residency had to be scheduled during the teacher's lunch time, on the days Jim was at the school.

\section{Participants Describe Strategies to Manage Problems (Research Question 1C)}

All three arts partnerships had been in place at the schools for several years at the time of the study. They were well-rooted in school life. Devising strategies to manage ongoing issues varied greatly, depending on the schools and the model of arts instruction. 
Valley Arts Studio: Setting up new partnerships. In her interview, Kim, VAS

Executive Director, recounted that the during-school arts program - the Rotating Arts

Wheel - had started. She stated that it had been difficult at first, as schools did not know about their organization at all even though VAS had been conducting after-school programs at their sites for several years. Kim said that teachers were "wary of us...they wondered are we trying to take their jobs. They were worried." However, this wariness did not last and the Rotating Arts Wheel program rapidly gained renown. At the time of my interview with Kim in January, 2017, the arts organization had more requests for arts programs than they could fulfill. Kim elaborated:

We can't accept any more work 'cuz we have no more artists. They're all booked. We start planning for next year and in preparation for those things - we have several that want to do band, so we don't have anyone currently that's available. Next year we'll make sure to get that artist available to do those programs (Interview Arts Organization Administrator 3).

Kim discussed the process of setting up a partnership with a district or a school. She explained that working with district/school administrators ensured that the arts curriculum was consistent across the grades. She added that establishing the partnership at the school or district level assured the VAS artists would have plenty of work. She said:

I think that's the best way to do it. We are guaranteed a certain amount of work for our artists and we can continue to evolve the program with the school district. There's no gaps....You have continuity through all the grades and all the schools. It's good for everybody. That's what we aim for (Interview Arts Organization Administrator 3).

She then explained how VAS and a district/school worked together to create an arts program that was tailored to their needs. She said: 
A school will say, "We would like to have a music program." We go in and we discuss what kind of music program they want. They'll say, "We want a music program that is mostly vocal music. General music, not instrumental; we don't want instrumental, we already have that." They tell us what they want. Maybe they want African drumming. Whatever. They will decide the parameters... We try to provide the artist that's a good match for the school and what they're requesting.

We always, in conversation with the school the year before, we discuss the curriculum. They see all the curriculum, the standards, and the framework that we build for each of them. If they wanna make changes they can. Some schools have asked for specialty or intensives. Maybe it's world music in third grade or maybe it's creating your own music in fifth grade. We work within the standards and we try to address any requests that the school have. Absolutely (Interview Arts Organization Administrator 3).

In her interview, Rosa, the principal at Shadow Brook, also spoke about her role in selecting the arts rotations for her school. She said:

At the beginning of the year, we were given a handout from Valley Arts Studio organization. It had a list of-for example, in dance it had a list of five different modalities or five different dance focuses. Hip hop, I think square dancing was one of them. I sat down with the other principals at the beginning of the school year. We went through each category. We're like, "Oh, this sounds really good for first grade. This sounds really good for fifth grade. We'd like to make these adjustments under the dance component" (Interview School Administrator 2).

For Kim and Mark, Director of Programs, the key to success for VAS resided in its readiness and ability to accommodate the districts/schools' requests, by providing them with a wide variety of programs and arts disciplines to choose from. Kim told this story:

One year when we were at a school they wanted a visual arts and a theater combined, and with language arts. We did Shel Silverstein and the beautiful poems that he wrote and we did an art project and we did a theater production, all associated under that same topic. We'll work with the schools to create something unique (Interview Arts Organization Administrator 3). 
Funding. Many schools VAS partnered with were Title 1 schools, which often had limited budgets for arts programs. Kim said that her organization helped these schools in two ways: 1) VAS provided help with grant writing so that the schools' budget for arts programs could be supplemented, and 2) VAS modified its arts program so it could be accommodated by small budgets. Further, Kim explained that the schools that had very limited budgets selected performing arts programs rather than visual arts programs. She explained the lower priority for visual arts programs as follows:

They won't necessarily understand the importance of visual arts curriculum. They feel like they can save money by not having a visual arts component and just do the performing arts. That their classroom teachers could figure out how to do it. It's not the right approach. They should understand that we're not teaching crafts; we're teaching art (Interview Arts Organization Administrator 3).

\section{Scheduling challenges that cross organizational boundaries. One of Mark's}

responsibilities at VAS was to create the arts rotation schedules - plus the schedule for each rotation—-for each partnership. He detailed the process:

What I do is for any school in particular, I'll go to the school's website and load what is called their bell schedule.... What I'll do is, using the computer, Excel, I'll build a schematic of a schedule of what I think would work, based upon the amount of classes that they [the schools] want. Some schools will have as few as 12 classes a week. Some schools will have as many as 32 classes a week. What I'll do is, based upon the amount of classes that they want and the schedule that the school has from day to day, I'll build something that I think will work with the school. Then I'll send it to the principal and the school administrator and say, "This is what I've built. Can you send it out to the teachers and let them sign up accordingly for a time that works well with them?" It will tell me like, "9:00 to 9:30, Mrs. Smith, second grade. 9:30 to 10:00, Mr. Smith, third grade..." It's a collaborative process from the very, very beginning. Otherwise, it wouldn't work. We couldn't tell a school, "This is your schedule. This is what you're going to get. Thanks so much. Here's our contract. Please give us a check by the end of the week" (Interview Arts Organization Administrator 4). 
To Mark, it was essential to resolve problems as soon as they appeared. He added:

Obviously, we want to talk to the teachers and make sure that they understand what it is that the artist is going to be teaching. If you do have problems, the best way to resolve them is to communicate them and flush things out and not point fingers or blame or name-call. Work out some sort of a solution that is amicable to everyone. If you can do that, you forge an even stronger relationship. It gives cause to see that we are a real professional company, and we do want to work with you and the kids, so that you'll have us back. Because not only are we providing quality arts educations, but we work with you throughout the entire process. It's not just a simple cut-and-dry, black-and-white thing (Interview Arts Organization Administrator 4).

Facility space. Kim and Mark were both very attentive -Mark called this "being attuned" - to the needs of each of the schools with which VAS partnered, and were willing to work out any issue that arose. However, schools sometimes presented issues that they could not control, particularly with regard to the availability of facility space. Mark explained that many of the schools they partner with were overcrowded. He gave the example of one school whose "normal capacity is around 650 [students]. Right now, they have about 830 [students]." Under these conditions, and speaking specifically about the visual arts, Mark added:

The only requirement that we absolutely have to have-well, there are two actually - is, one, storage for the art supplies the teacher is going to be working with. Whenever they go into a room to teach a class, the classroom must have a working sink for cleanup, essentially. Other than that, we have to be amenable toward the restrictions that the schools have and work with them (Interview Arts Organization Administrator 4).

Shadow Brook. As described above, great attention and careful planning were given to the arts curriculum and the rotation schedules; based on my interviews with the teachers and the principal, the arts rotations usually functioned as well-oiled machines. 
However, there was no mechanism to address ongoing challenges. For example, the issue of sharing a room with the afterschool program existed during Jean's first residency and persisted her second residency.

In another example, Rosa, the principal, was not happy with the tight schedule of the visual lessons. However, she felt she had no capacity to resolve the issue, as the program was district-funded. She said:

This is beyond my control. I'm sure it's beyond Valley Arts Studio. I wish students had longer sessions. Already, Valley Arts Studio for the visual arts is longer than our typical sessions, which are 30 minutes. Visual arts is 45 minutes. I wish we had even longer. I feel like to really-by the time students sit down, get their materials, listen to the instructions, maybe get a model, and really get going and start working, sometimes it's like, "Oh, okay. You gotta clean up." I wish we had a longer time.

I don't know. I mean, they've already made an adjustment. I think it has to do with - I mean, I'll bring it up. I think it's controlled at the district level, too, 'cause it has to do with funds and how much it costs (Interview School Administrator 2).

Further, she commented on the teachers' behaviors during the arts classes, of which she seemed to disapprove. She told me that when she was a teacher, she would take advantage of the art classes and would participate along with her students. At the same time, she explained, it was a complex problem. She attempted to explain these behaviors:

I think it just depends on the teacher. I think it depends on the other demands they're having at that very moment, whether it's making sure that they're prepared for when they do go back to the classroom. I think it just varies.

I mean, obviously, ideally it'd be great if a teacher was 100 percent involved, almost co-facilitating the class, walking around, helping students out, so it's not just Jean, right, and help manage those behaviors if any come up. I think it just, it depends on a lot. It depends on where the teacher is at that very moment. It depends on teacher experience. I mean, that's a good question. It's good feedback, too, for me to go back and say, "Hey, take an opportunity. Valley Arts Studio is not-it's not a prep time. 
It's not time where you just sit back...no...I think that's a bigger, larger conversation (Interview School Administrator 2).

Strategy: Hiring experienced teaching artists. In order to provide quality programs, both arts organizations sought to hire capable teaching artists. Their hiring processes were quite similar and very rigorous. Most candidates came through referral. They went through a series of interviews, and then would be placed in a classroom setting to demonstrate their teaching abilities.

Mark, Director of Programs at VAS, described the ideal candidate as follows:

When we choose an artist, we try to choose someone that already has teaching experience, hopefully a lot of it, is well-rounded in their discipline, so that if they go into a classroom and there's a kid that's there that may not want to participate in it, they have enough tricks in their bag to actually engage the student and get the student interested. This, I think, is a major important point, is that these during-school programs, all of the kids do it, whether they like it or not. We have to have someone that goes into these schools that it is competent, confident, and versatile, so that they're able to work with a problem student, or sometimes even teachers may have questions or may have issues with some of the curriculum that we talk about (Interview Arts Organization Administrator 4).

Kim, Executive Director, also commented on classroom management, underlining the need for teaching artists to have strong management skills. To that end, VAS offered a two-hour training on classroom management once a year. However, the arts organization could not require the teaching artists to attend in the training because they were contractors to VAS. She explained:

In terms of - I mean we believe that it's very important for them to have strong classroom management skills because without that no learning will happen. We do provide professional development. It is not mandatory because they're all contractors. If they choose to come, we pay them for it, but we can't make them come 'cuz they're not our employees (Interview Arts Organization Administrator 3). 
The CftA's hiring process followed the same steps. While teaching artists were, sometimes, recruited through recommendations, Murphy told me that she was always looking for new teaching artists, particularly in the visual arts, and that she had to actively search for candidates. To that end, she had created a profile for the position, which was always posted on the arts organization website. She shared this document with me; Figure 7 shows an excerpt of the position description.

\section{Responsibilities:}

- Work professionally as a visual or performing artist and artist educator

- Be able to draw curriculum connections, most specifically with English Language Arts, Math, and Science Curriculum

- Have previous experience working with arts integration in schools as a teaching artist and be able to provide references from such work

- Be able to work collaboratively with teachers and administrators

- Be organized and able to communicate effectively to collaborating teachers in a timely manner

- Be willing and able to attend professional development sessions for both Teaching Artists and teachers

- Flexible, positive, creative, and willing to adapt teaching to each specific residency

Figure 7. Excerpt of teaching artist job description.

Strategy: Integrating the arts into the curriculum. Developing integrated curricula

was key to the TAP model. In that way, each residency was unique, since its curriculum was customized for each school's needs. Murphy, the Director of Education at CftA, explained that some artists could immediately see how their work fit with academic subjects, whereas others could not. She elaborated:

I think there are certain artists that can see where math is in their work or where science is in their work or where English is in their work more than others. For some artists, that's very easy. They see it right away and they feel like, "Actually, my work is about math," or, "My work is about 
science." In other cases, we're working with artists to help identify that and helping them gain skills around how to leverage their work to work around the learning and understanding of this academic content (Interview Arts Organization Administrator 1).

Murphy was essential in facilitating the process of pairing an artist's art form with academic content. She described herself as speaking "the language of a lot of different artistic disciplines;" she was an accomplished visual arts artist, musician, and vocalist, and she had taught a variety of academic disciplines in addition to teaching visual arts. She spoke about her role during the first teaching artist/classroom teachers planning meeting that took place before the residency:

A lot of times why I also wanna sit in on these meetings is part of what I love about this work, part of what really keeps me so committed to this program and developing this program is this is emergence of my two worlds. A lot of times in those meetings, I can have either a teacher trying to explain something that I have to translate to the artist or vice versa, or we're looking at subject matter and I try to facilitate ideas where I see them surface. Again, because they're all so hand-tailored, that could be a million things (Interview Arts Organization Administrator 1).

Strategies at Cypress and Orchard. Teachers at Cypress had worked with a variety of teaching artists since the beginning of the partnership with CftA, and they had used different approaches to pair the art form with the academic content. Depending on the timing of the residency—spring or fall—they would, in some instances, choose the art form first and then the academic content upon which they wanted to focus; other times, they did the opposite, selecting the academic content first, and then the art form. For the 2016 residency, the teachers asked for Florence, whom they already knew, since she had worked at Cypress in a previous residency. They also were aware of Florence's unit on water conservation and they wanted this to be the content of the residency. Karen said: 
We requested Florence this time and so the kind of the artist was the part that led this time. We were able to work with her only in fall 'cuz she's so wonderful and so busy. Because of that, we had some challenges with the curriculum - which often happens - and so we were able to kinda come up with this new way where we really just focused on the art more than the art and the curriculum part with it. Which we had done more teaching in our own classrooms in years past, where this time Florence did most of the information and the art (Interview Teacher 7).

While the teachers recognized that Florence's projects did not dovetail with their class curriculum, they appreciated her flexibility and openness to modify her lessons so they could connect, however approximately, to the classroom curriculum. Heidi said:

I think Florence went through a lot of effort trying to connect it to our curriculum, which didn't have a lot of provision - we were like teaching government at the time, so it wasn't ideal. I think you went through a lot of effort to like, "Okay, well, let's focus on the community side" (Interview Teacher 6).

They also discussed the combination of visual arts and science, which they said worked well for them and for their students, as it helped to deepen their understanding of scientific concepts. Heidi elaborated:

I think five years ago when we did - the very first time we did it, we were instructed that it needed - the content we were attaching it to was writing and I know that very first year it was a big struggle to feel like how do we just match this with writing. I think in the years since, especially through - in my opinion - doing it with science has been a really nice way to open up how it would enhance their learning and help them [the students] understand in a different medium because for a lot of our kids, it does help them access it. I think that-I would say the very first year trying to connect it just with writing felt like a struggle because I felt like it didn't open us up to see how could we fit this in to give them a deeper understanding. That's been nice to connect it with science to me; it's like helps them see it another way (Interview Teacher 6).

Florence, the teaching artist at Cypress, commented on the various visual arts/science curricula she developed for her residencies over the years. She thought the lessons should 
not tie too closely to the classroom textbooks and standards, as they became obsolete each time the school adopted new curriculum. To avoid this problem, she stated, the visual arts/science curriculum should address themes that were broad and rooted in people's lives. In that way, the lessons would always be relevant, since they were more easily adaptable to any classroom learning. She explained:

The model [arts integration] is complicated. For example, in science, if you work with units, at school, it changes all the time...If I create a unit in science, like, for example, the insect unit that I think was beautiful and really cool, and the teachers were super excited. I did it once. The year after, it was gone from the curriculum of second grades. Teachers were like, "We want to do it, but there is no application for it because we are done with insects. We don't do that unit."

Asking that question it's, "Okay. How can we go around that?" That's the idea of asking the artist, what do you like? What are you very interested in? For example, me, water. Create something that will never go away. Water will not go away, the importance of water. Create that, and it will stay. Then, branch out to a poem, a text, human - something about history or whatever, but you can still have it around (Interview Teaching Artist 2).

Jim, the teaching artist at Orchard, shared similar views about integrated learning; he explained how his work taught students foundational skills that could be adapted to any school curriculum. He said:

What I see a program like this is about is providing foundational skills, both behaviorally, as well as artistically. Once you have the foundation, trying to a look at how you use this in different ways, how to use it for science, how to use it when they change the curriculum to core, how to use it because, if it is too specific, as soon as the curriculum changes, the program is gone. It has to be seen as a real foundational way to work with the art forms. It's like, instead of teaching how to make Chinese food or French food, how do you work in the kitchen? What are the implements you use? How do you arrange things? Then you can use them in all these different ways. Once you have that skill, everything else becomes obvious or becomes a small trial and error, as opposed to something that has a huge pitfall (Interview Teaching Artist 1). 
Florence saw arts integration as a way to "drive teachers in," that is, to engage teachers with art so they felt less intimidated by the "art part" of her lessons. She spoke about a set of lessons on "Forces and Motion," a science/visual art unit she had created for a previous residency. She described how teachers had participated in the lessons:

It's maybe because of the content. Let's say, forces and motion, they [the teachers] knew their unit very well, of course, but much better than I did because I never taught forces and motion...I guess they felt empowered, and they understood everything we were doing, even if there were techniques and stuff- the art techniques were on top of this knowledge and content, but they could navigate the content very, very easily, and they could say things about that anytime... That was a very easy way, I think, for them to [participate] - I can see that in each and every unit I did since (Interview Teaching Artist 2).

She continued, speaking about the teachers' participation at Cypress:

Even now that I create my own curriculum with the water, before we start, I can talk to them about - they see what I will do, and they say, "Oh, yeah. We can do this and maybe that. Sometimes, at Cypress, they propose to me, they say, "Florence, do you want us to show a video before we come to the class?" They discuss with the kids, and they show the video, and they have this - they bridge, I think.

They usually don't discuss the art...In a way, water is a unit I created that is across - well, then they say, "Oh, we can plug this here, and that here... I have more lessons than I can do in a residency. I say, "Okay, I have this and this and this. What do you think?" Then they make a puzzle because we know that this exercise will take two sessions, this one, three, this one, one. It's like a puzzle, and we decide, together, how we are going to start and to finish. They can see, in their classroom, how it fits...With that, I think they feel less the art aspect of it (Interview Teaching Artist 2)

Strategy: Collaboration. As teaching artists and classroom teachers worked together, collaboration flourished. As a part of this, they grew to appreciate the unique skills each participant brought to the partnership. However, the collaboration took distinct paths at Cypress and at Orchard. 
Collaboration at Cypress. Collaboration between teachers and resident artists could not develop over the years, due to the fact that the teaching artists were usually different each year. However, teachers spoke enthusiastically about Florence's residency and Heidi described how they had worked together:

I think Florence's great. Well, for me, I feel like you were very great about like, "Here's how you could help me with this," or like, "What would you like in this? What exactly are you doing? What works for your students?" I feel like you're always communicating. That wasn't always the case with all of the residents we were working with (Interview Teacher 6).

Speaking more generally about the Teaching Artist Program residencies, Karen added that she preferred a model of collaboration in which the TA and the teachers acted as partners and worked as a team to teach the lessons, rather than having to teach complete lessons alone. She said:

I like how we did it with Florence, where it was more team teaching because it feels more comfortable that way. I'll speak to last year, because we did do where we had to teach two lessons because it was the second year we had been with that artist. I felt like he was not part of it, but that made me feel more intimidated to be teaching in front of this artist 'cuz he was very disconnected and it was like he was just listening. It made me feel more - it made my anxiety go up more, whereas with Florence when we collaborate and we do it together, it feels like we're doing this thing together. I can ask her, "How 'bout this?" The same thing: We can kind of bounce ideas off of each other so it feels more collaborative, where if like, "Well, you're gonna do my job today," which is how it felt with other artists (Interview Teacher 7).

Collaboration at Orchard. At Orchard, on the other hand, the teacher-artist resident collaboration had flourished over the years and made the partnership highly successful, particularly in its goal of building teacher capacity. Murphy, Director of Education at CftA, said:

What we're seeing now in our fourth year is those teams that have stayed with the same artists and the same discipline, such as Orchard, you can see 
the impact that it's having on the way these teachers approach their practice; that this is now embedded in the way that they work with their students, some of the language that they use with their students. It has changed the way that they teach and that's absolutely what we want (Interview Art Organization Administrator 1).

Maggie described the collaboration process at Orchard:

In the beginning, in the first year, it was more Jerry's ideas 'cuz we had no clue what the whole program was about. As the years went on, and we had to take on more responsibility, it was like a marriage of the two, so we came with ideas, he came with his, and we bounced ideas off each other, and it helped us get to where we want to be (Interview Teacher 2).

Four years into the TAP program at the time of this study, both teachers and teaching artist contributed equally to the development of the curriculum. In addition, the teachers had started leading some of the acting activities. In preparation for the residency in the fall of 2016, the teachers communicated to CftA the elements of Jim's practice they wanted to integrate into their classroom learning. Figure 8 shows these elements.

Through what we have observed and learned over the past four years, we have pinpointed several elements that we can commit to incorporating into each year's curriculum:

1. creating tableaux for better comprehension of understanding and expression of vocabulary as is applicable to the curriculum

2. practicing mindfulness through breathing techniques; awareness of personal body space; and reducing tension within the body, all of which can improve learning and being with others

3. learning how to incorporate "thinking" and "feeling" into our decisions

Figure 8. Excerpt of the correspondence between the teachers and the CftA.

In order to give teachers more time to practice leading activities during Jim's residency, his schedule was arranged to support this. Rather than scheduling sessions once a week for ten weeks, some lessons were scheduled twice per week and one two-week gap was put into the schedule so the teachers could lead lessons when the TA was not present. The 
following, Table 10, which I constructed from documents Murphy shared with me (that is, planning notes and email correspondence between the teachers and the TA), shows the residency schedule as well as some detail about the lesson content. 
Table 10

Residency at Orchard: Schedule and Lesson Content

\begin{tabular}{|c|c|}
\hline $\begin{array}{c}\text { Residency Days } \\
\text { (Total of } 10 \text { sessions) }\end{array}$ & Lesson Content \\
\hline $\begin{array}{l}\text { Day } 1 \text { and } 2 \\
\left(\text { September } 13^{\text {th }}-14^{\text {th }}\right) \\
\text { Teaching artist-led lesson }\end{array}$ & Fundamental work: shape by yourself, shape in groups \\
\hline Next two weeks & $\begin{array}{l}\text { Teacher-led lessons (once each week) } \\
\text { Teaching artist (TA) is not present - teachers try things on their own }\end{array}$ \\
\hline \multirow{2}{*}{$\begin{array}{l}\text { Day } 3 \text { and } 4 \\
\left(\text { October } 4^{\text {th }}, 5^{\text {th }}\right) \\
\text { TA-led lesson }\end{array}$} & $\begin{array}{l}\text { Ocean/mindfulness period at the opening of each lesson } \\
\text { Tableaux exercises around Where the Wild Things Are }\end{array}$ \\
\hline & $\begin{array}{l}\text { October } 5^{\text {th }} \text { : Lunch time planning meeting } \\
\text { Debrief previous lessons and plan next sessions }\end{array}$ \\
\hline $\begin{array}{l}\text { Day 5: Oct } 11^{\text {th }} \\
\text { TA-led lesson }\end{array}$ & $\begin{array}{l}\text { Ocean/mindfulness warm up activity } \\
\text { Tableaux exercises around Where the Wild Things Are }\end{array}$ \\
\hline \multirow[t]{2}{*}{$\begin{array}{l}\text { Day 6: Oct } 19^{\text {th }} \\
\text { TA-led lesson }\end{array}$} & $\begin{array}{l}\text { Ocean/mindfulness warm up activity (TA) } \\
\text { Content for this lesson not available }\end{array}$ \\
\hline & $\begin{array}{l}\text { Lunch time planning meeting } \\
\text { Debrief previous lessons and plan next sessions }\end{array}$ \\
\hline $\begin{array}{l}\text { Day 7: October } 26^{\text {th }} \\
\text { TA-led lesson }\end{array}$ & $\begin{array}{l}\text { Ocean/mindfulness warm up activity } \\
\text { Tableaux and slow motion around Pecos Bill story }\end{array}$ \\
\hline $\begin{array}{l}\text { Day 8: November } 2^{\text {nd }} \\
\text { Teacher-led lesson }\end{array}$ & $\begin{array}{l}\text { Ocean/mindfulness warm up activity (TA) } \\
\text { Tableaux and slow motion around Pecos Bill story }\end{array}$ \\
\hline $\begin{array}{l}\text { Day 9: November } 9^{\text {th }} \\
\text { Teacher-led lesson }\end{array}$ & $\begin{array}{l}\text { Ocean/mindfulness warm up activity (TA) } \\
\text { Students explore Pecos Bill scenes in more depth } \\
\text { Goal: Examination of subtext and context in Pecos Bill. } \\
\text { Jim gave suggestions to the teachers: } \\
\text { "Have the kids make the same tableaus as last week. The audience gets to } \\
\text { ask questions to the characters in the scene. For example, "Horses, who is } \\
\text { the better driver, Pecos Bill's mother or father? Why?" Or, "Coyotes, what } \\
\text { was it like having Bill join you?" Students will begin to learn to formulate } \\
\text { open-ended questions, and reach for answers. This is a slow learning } \\
\text { process, but I think it's valuable." }\end{array}$ \\
\hline \multirow[t]{2}{*}{$\begin{array}{l}\text { Day 10: Nov } 16 \\
\text { Teacher-led lesson }\end{array}$} & $\begin{array}{l}\text { Ocean/mindfulness warm up activity (TA) } \\
\text { Each teacher choose the theme for the activities } \\
\text { T1: shapes by yourself with vocabulary words (Language Arts) } \\
\text { T2: tableaux: vocabulary words from science unit } \\
\text { T3: tableaux: vocabulary words (Language Arts) } \\
\text { T4: tableaux: vocabulary words from science unit on Plants and Animals }\end{array}$ \\
\hline & $\begin{array}{l}\text { Lunch time meeting } \\
\text { Debrief morning sessions }\end{array}$ \\
\hline
\end{tabular}


Building relationships. In discussing their experiences with the residencies, the teachers and TAs described the ways in which they collaborated (or failed to collaborate). In most cases, they spoke of relationships that matured as they worked alongside one another. Whether the relationship came first and the collaboration grew from that or the relationship developed as TAs and teachers worked together, one did not thrive without the other. For example, Jackie explained that because she trusted Jim, she was willing to try things that made her uncomfortable. Jim felt that because he and the teachers had a “deep relationship, they could work together." Speaking of his 2016 residency at Orchard, he expanded on this:

I think that we are getting closer, and it's getting easier and easier because you can sense what I'm doing, and I know when I can cut in and when I shouldn't cut in. That's been really nice, and I feel like, this year, we really achieved a maturity in our collaborative relationship that was different than other years. This fourth year's been very nice and very rare for me to have (Interview Teaching Artist 1).

Florence and the teachers at Cypress shared the same view. For them, the success of the CftA residencies was dependent on the teaching artist remaining at the same school for several consecutive years, so a relationship between the teaching artist and the teachers could develop, based on mutual understanding of one another's daily responsibilities. Speaking of her experience working with Florence, Heidi said:

I really appreciate that perspective that you [Florence] have, too, on what our side of it is [the teachers' responsibilities outside the partnership] as well, 'cuz I feel like you really embody the collaboration piece of it...because I think that that was something that was missing sometimes in past ones [residencies], where it was like, "Oh, well, can you finish this up with them tomorrow? The rest of this week, can you finish this art project?" and I would be like, "Where? Where do you want me to fit that in my schedule to finish this project?" or this where they [the students] had to write a song or something that was like, "I didn't plan that into my week and I wish that I could, but I'm 
not_-" I think there was this assumption that like, "Oh, you can just finish it in your own classroom time." It feels like you have a level of respect and back and forth where I think we see how much you are doing to prepare for this and it's like wow, look at all these things. You've prepared lessons and a unit plan and the materials and I think you also have that vision of us and it felt like a lot of respect and collaboration on that (Interview Teacher 6).

In her interview, Florence discussed her residency at another elementary school, which was part of the same district as Orchard and Cypress, where she had been working for three years. She described the connection she had with the second grade teachers as follows: "Now we have this collaboration and this flow... we already know what's coming up and how to improve it." She also spoke of the collegial partnership that she had developed with the principal over the years:

I'm close to the principal, and we like to see each other to talk about things that we- "Oh, did you see this? Did you see that?" "Oh, yeah." For example, if you went to a conference, so if I-we share stuff. That's the way it should be, but it's very, very rare. I can tell that [name of the school] works very well because there is this relationship, too. There is a very, very clear endorsement of the arts by the principal. The principal thinks it's one of the most important things (Interview Teaching Artist 2).

According to Florence, the camaraderie she shared with the principal, as well as the relationship that existed between the principal and the teachers, were a very important factor in the school's desire to expanding the partnership with CftA. In addition to her regular $2^{\text {nd }}$ grade residency that was scheduled in spring 2017 , the principal invited Florence to create a new residency model in the fall of 2016 that would involve all the students, from Kindergarten to grade five. This additional residency lasted two weeks, with Florence being at the school every day of the week. Florence spoke with enthusiasm about this new residency and the effect it had on the teachers: 
I went to [name of the school] for two weeks and all the grades-I worked together with all the grades, so, at that time, I was there every day, worked with all the teachers, and they were talking to each other, and it makes it dynamic. For two weeks, we do a one-okay, one project was not much, but I do all the grades, and it's kind of a party in the school because I go from-and, at lunch, they [the teachers] could talk to each other about the project. They were like, "Oh, yeah, we are doing this is. It's very cool. Oh, yeah, we have this today. I can tell how I can use this on-,", and it was very, very, very interesting (Interview Teaching Artist 2).

\section{Summary of Chapter}

The present study investigated arts education programs in three California elementary schools using a qualitative approach to gather data. This chapter presented the findings that emerged from a detailed analysis of interview transcripts, classroom observations, and field notes. The findings were organized into four main themes, which were: 1) a description of the participants' perceptions of and perspectives on the artists residencies, 2) the benefits participants reported they gained from the arts partnerships, 3) the ongoing challenges and obstacles they faced, and 4) the strategies they devised to manage these issues. Table 11 presents a summary of the key findings, highlighting similarities and differences across the school sites. 
Table 11

Summary of Findings: Similarities and Differences

\begin{tabular}{|c|c|c|c|}
\hline \multirow{2}{*}{$\begin{array}{c}\text { FINDINGS: } \\
\text { SIMILARITIES } \\
\text { AND } \\
\text { DIFFERENCES }\end{array}$} & \multicolumn{2}{|c|}{ CENTER FOR THE ARTS } & \multirow{2}{*}{$\begin{array}{c}\text { VALLEY ARTS } \\
\text { STUDIO } \\
\text { SHADOW BROOK } \\
\text { ELEMENTARY }\end{array}$} \\
\hline & $\begin{array}{c}\text { CYPRESS } \\
\text { ELEMENTARY } \\
\end{array}$ & $\begin{array}{c}\text { ORCHARD } \\
\text { ELEMENTARY } \\
\end{array}$ & \\
\hline $\begin{array}{l}\text { Partnerships } \\
\text { characteristics }\end{array}$ & $\begin{array}{r}\text { Single Grade le } \\
\text { Arts i }\end{array}$ & $\begin{array}{l}\text { (Second Grade) } \\
\text { egration }\end{array}$ & $\begin{array}{c}\text { Grades K-5 } \\
\text { Standards-aligned } \\
\text { instruction in the visual } \\
\text { arts (VA) and performing } \\
\text { arts (PA) } \\
6 \text { weeks arts rotations } \\
\text { Six 45-minute long } \\
\text { sessions for VA and six } \\
\text { 30-minute long sessions } \\
\text { for PA }\end{array}$ \\
\hline $\begin{array}{l}\text { Art form/ } \\
\text { instruction } \\
\text { observed }\end{array}$ & $\begin{array}{l}\text { Integration of visual arts } \\
\text { and science }\end{array}$ & $\begin{array}{l}\text { Integration of drama } \\
\text { techniques with various } \\
\text { classroom curricula }\end{array}$ & Visual arts instruction \\
\hline $\begin{array}{l}\text { Facilities for the } \\
\text { residencies }\end{array}$ & \multicolumn{3}{|c|}{ No specific space was allocated to the arts residencies } \\
\hline \multicolumn{4}{|c|}{ Appreciation of the partnerships and benefits } \\
\hline $\begin{array}{l}\text { Appreciation for } \\
\text { the partnerships }\end{array}$ & Overall positive & Positive & Overall positive \\
\hline $\begin{array}{l}\text { Teachers and } \\
\text { principals' reports } \\
\text { about the impact } \\
\text { on students }\end{array}$ & $\begin{array}{l}\text { The residencies helped } \\
\text { children build self- } \\
\text { confidence and deep } \\
\text { thinking } \\
\text { "It gives them a place to } \\
\text { shine" (Heidi, teacher) }\end{array}$ & $\begin{array}{l}\text { The residency taught life } \\
\text { skills; students learned } \\
\text { self-awareness and } \\
\text { dealing with feelings }\end{array}$ & $\begin{array}{l}\text { The arts were a way for } \\
\text { students to express } \\
\text { themselves, and to be } \\
\text { creative and successful }\end{array}$ \\
\hline $\begin{array}{l}\text { Impact on } \\
\text { teachers }\end{array}$ & $\begin{array}{l}\text { Teachers saw the arts as } \\
\text { instructional tools they } \\
\text { could use in class }\end{array}$ & $\begin{array}{l}\text { Teachers integrated drama } \\
\text { techniques into their daily } \\
\text { classroom activities }\end{array}$ & $\begin{array}{l}\text { The teachers regarded the } \\
\text { arts rotations as } \\
\text { supplemental rather than } \\
\text { being fundamental to } \\
\text { learning }\end{array}$ \\
\hline $\begin{array}{l}\text { Place of the arts in } \\
\text { the school } \\
\text { curriculum }\end{array}$ & \multicolumn{2}{|c|}{$\begin{array}{l}\text { Only second grade had access to the arts program; the } \\
\text { residencies were considered a "Core Curriculum Area" } \\
\text { in the schools' SARC }\end{array}$} & $\begin{array}{l}\text { There was no mention of } \\
\text { the VAS arts program in } \\
\text { the school's SARC } \\
\text { "It takes a back seat to } \\
\text { everything else" (Rosa, } \\
\text { principal) }\end{array}$ \\
\hline
\end{tabular}




\begin{tabular}{|c|c|c|c|}
\hline \multicolumn{4}{|c|}{ Burdens and challenges } \\
\hline $\begin{array}{l}\text { Challenges for } \\
\text { teachers: } \\
\text { Curriculum } \\
\text { integration }\end{array}$ & $\begin{array}{l}\text { Frequent changes in the } \\
\text { classroom curricula often } \\
\text { made the residency } \\
\text { lessons obsolete }\end{array}$ & $\begin{array}{l}\text { Residencies were not } \\
\text { affected by curriculum } \\
\text { changes }\end{array}$ & N/A \\
\hline $\begin{array}{l}\text { Challenges for } \\
\text { teachers: } \\
\text { Collaboration/ } \\
\text { planning time }\end{array}$ & \multicolumn{2}{|c|}{ No specific time for collaboration } & $\begin{array}{l}\text { No collaboration, causing } \\
\text { communication } \\
\text { difficulties }\end{array}$ \\
\hline $\begin{array}{l}\text { Challenges for } \\
\text { teachers: } \\
\text { Effective TA- } \\
\text { teacher match }\end{array}$ & $\begin{array}{l}\text { Some difficulties to find } \\
\text { the right match }\end{array}$ & Not an issue & N/A \\
\hline $\begin{array}{l}\text { Challenges for } \\
\text { teachers: } \\
\text { Fast-paced lessons }\end{array}$ & Not an issue & Not an issue & $\begin{array}{l}\text { Lower grade ELL } \\
\text { students had difficulty } \\
\text { following instructions, } \\
\text { particularly for the visual } \\
\text { arts lessons }\end{array}$ \\
\hline $\begin{array}{l}\text { Challenges for } \\
\text { Teaching artists: } \\
\text { Art space }\end{array}$ & $\begin{array}{l}\text { Sharing room with other } \\
\text { activities did not allow the } \\
\text { visual artist resident to } \\
\text { prepare materials on site }\end{array}$ & $\begin{array}{l}\text { Not an issue for the drama } \\
\text { teaching artist, since he } \\
\text { needed no material } \\
\text { preparation time }\end{array}$ & $\begin{array}{l}\text { Sharing room with other } \\
\text { activities did not allow the } \\
\text { visual artist resident to } \\
\text { prepare materials on site }\end{array}$ \\
\hline $\begin{array}{l}\text { Challenges for } \\
\text { Teaching artists: } \\
\text { Tight schedule }\end{array}$ & $\begin{array}{l}\text { Back-to-back classes were } \\
\text { stressful for the visual } \\
\text { artist, who had no time to } \\
\text { socialize with faculty and } \\
\text { school staff; TA felt } \\
\text { isolated }\end{array}$ & Not an issue & $\begin{array}{l}\text { Back-to-back classes were } \\
\text { stressful for the two visual } \\
\text { artists, who had no time to } \\
\text { socialize with faculty and } \\
\text { school staff; TAs felt } \\
\text { isolated }\end{array}$ \\
\hline $\begin{array}{l}\text { Challenges for } \\
\text { Teaching artists: } \\
\text { Classroom } \\
\text { management }\end{array}$ & \multicolumn{2}{|c|}{$\begin{array}{l}\text { Not an issue. Teachers fully participated in the } \\
\text { residency lessons and took care of discipline }\end{array}$} & $\begin{array}{l}\text { Was an issue, as teachers } \\
\text { did not participate at all in } \\
\text { the arts residencies }\end{array}$ \\
\hline $\begin{array}{l}\text { Challenge for Arts } \\
\text { organizations: } \\
\text { Hiring visual } \\
\text { artists }\end{array}$ & \multicolumn{2}{|c|}{$\begin{array}{l}\text { Finding artists who were able to connect their art form } \\
\text { to an academic subject was a challenge }\end{array}$} & $\begin{array}{l}\text { VAS had no difficulty } \\
\text { hiring performing artists } \\
\text { compared to visual artists }\end{array}$ \\
\hline $\begin{array}{l}\text { Challenge for } \\
\text { Schools and Arts } \\
\text { organizations: } \\
\text { Continuity within } \\
\text { the programs }\end{array}$ & \multicolumn{3}{|c|}{$\begin{array}{l}\text { As artists were contractors there was no guarantee that the same teaching artists } \\
\text { would return to the same school each year. }\end{array}$} \\
\hline
\end{tabular}




\begin{tabular}{|l||l|l||l||}
\hline \multicolumn{3}{|c||}{ Strategies } \\
\hline Curriculum & $\begin{array}{l}\text { The visual artist created } \\
\text { lessons addressing broad } \\
\text { themes that related to } \\
\text { real-word issues }\end{array}$ & $\begin{array}{l}\text { The drama teacher } \\
\text { focused on developing } \\
\text { foundational skills that } \\
\text { could be applicable to any } \\
\text { curricula }\end{array}$ & No strategies \\
\hline Collaboration & $\begin{array}{l}\text { For 2016, teachers } \\
\text { requested a specific TA }\end{array}$ & $\begin{array}{l}\text { TA-teachers long } \\
\text { relationship made } \\
\text { effective collaboration } \\
\text { possible }\end{array}$ & No collaboration \\
\hline
\end{tabular}

The goal of Table 11 was to provide readers with an overview of major findings and differences across sites. The table was organized by research questions, including summary of partnership characteristics, appreciation and benefits, burdens and challenges, and strategies. Chapter five presents an overview of the study, summarizes and further discusses some of these findings. It concludes with recommendations for practice, leadership, and future research. 


\section{Chapter 5}

\section{Discussion}

\section{Introduction}

The purpose of this study was to examine arts education partnerships in elementary schools, using qualitative research methods. Chapter Four reported the findings that emerged from a thematic analysis of the data. This final chapter begins with a summary

of the study itself; it continues with a summary of the findings and a discussion of the key themes as they related to previous research in the field of arts education. The chapter concludes with recommendations for leadership, practice, and future research.

\section{Summary of the Study}

The arts are vital components of a balanced education. They foster mental habits such as divergent and critical thinking, reflection, self-criticism, and the willingness to experiment and learn from mistakes (Hetland, Winner, Veenema \& Sheridan, 2013). Further, through learning in the arts, students grow to appreciate the diversity of the world's cultures, and develop empathy. Children need to acquire these skills and habits of mind to lead successful lives in the $21^{\text {st }}$ century. Yet, such skills are rarely emphasized in other core elementary curriculum areas (Winner \& Hetland, 2007).

Despite a growing body of literature that strongly suggests that education in the arts positively affects the cognitive, social, and emotional development of students (Brouillette, 2012; Burton, Horowitz \& Abeles, 1999; Duma, 2014; Catterall, Dumais \& Hamden-Thompson, 2012; Heath, Soep \& Roach, 1998; Peppler, Powell, Thompson \& Catterall, 2014), the number of arts programs has dramatically decreased in public 
schools in the last two decades, mainly as a consequence of No Child Left Behind (NCLB) policies (Au, 2007; Baker, 2012; Berliner, 2011; Freedman, 2007). This was particularly true in California: a 2007 statewide study revealed that only $10 \%$ of elementary schools provided standards-aligned arts programs in each of four disciplines: dance, music, theatre, and visual arts (Woodworth et al., 2007). When such programs were available, however, they were frequently offered through arts education partnerships with local arts organizations (Guha, Woodworth, Kim, Malin \& Park, 2008).

The present study set out to investigate arts education practices in elementary schools, specifically, when arts programs were provided through a partnership between a school and an arts organization. Chapter Two provided an overview of the federal and state arts education policies of the last 30 years, discussed the importance of arts education and the benefits students gained from learning about and through the arts, and examined the role arts education partnerships played in maintaining arts programs in public schools. In order to gain a deep understanding of how these partnerships functioned, this study analyzed and compared three arts partnerships that involved two arts organizations and three elementary schools in the South San Francisco Bay Area. The sites were described in Chapters Three and Four.

The overarching question that guided the design and methodology of this study was: How did the various institutional actors (schools and arts organizations, administrative staff, classroom teachers, and teaching artists) describe their experiences working within an arts partnership? To better address this question, three sub-questions were considered. They were: 
- What benefits did the various institutional actors listed above derive from the partnership?

- What burdens and obstacles did participants face when they were involved in the partnership?

- What strategies did they utilize to navigate or manage the issues that arose in the partnership?

Qualitative research methods were used to answer these questions. The main sources of data were individual and group interviews, classroom observations, and field notes. Various documents provided additional data; these included the arts residency schedules at each school, e-mail correspondence between the classroom teachers at Orchard Elementary and the teaching artist, public information about the schools and arts organizations, and photographs of the schools' buildings and student artwork.

\section{Summary of Findings and Discussion}

The analysis of the data yielded findings that were common to the three partnerships, while other findings showed distinct differences. Some of these differences derived from the model of arts instruction, that is, whether it was a stand-alone or an arts-integrated program. Other differences in the findings were linked to the position and responsibilities of the participants.

Participants' experiences of the partnerships. Overall, the participants' perceptions of the partnerships were favorable across the three campuses. School administrators and classroom teachers appreciated the residencies' curricula and the teaching artists' deep knowledge of their disciplines. They reported the positive effects the arts programs had 
on their students, highlighting a growing self-confidence and a sense of accomplishment. For the students who struggled with academic subjects, it gave them "a place where they shine" (Heidi, teacher at Cypress). Teachers also noted that when arts instruction was incorporated into the core curriculum, it offered students new ways to show their understanding of academic content, and to more effectively recognize and express their feelings. Although studying the impact of arts programs on students was not the focus of this study, the participants' comments on that subject corroborated the increasing evidence previous studies have revealed: that the arts are beneficial to students' socioemotional skills (Brouillette, 2010; Duma, 2014) and overall academic performances (Brouillette, 2012; Caterall, Dumais \& Hampden-Thompson, 2012).

The findings, however, showed that there was a significant discrepancy between the schools staff's discourse (i.e. the expressed appreciation for the arts partnerships and stated belief that the arts are essential to a child's education) and the reality in which these partnerships took place (i.e. the low priority given to the arts in the schools' curricula). This was more pronounced at Shadow Brook, where arts instruction was delivered as a stand-alone program. While the teachers and the principal were appreciative of the Valley Arts Studio's Rotating Arts Wheel, they considered it to be completely separate from the rest of the school curriculum. In addition, the arts were seen as supplements to the school's programs, rather than being fundamental to the learning process. At the two other schools, the arts residencies, according to the principal at Cypress, were an "integral" part of the school curriculum. Yet, not all students had access to the arts programs, since the partnerships were a district initiative that provided arts 
residencies to a single grade level, the 2 nd grade. Students in other grade levels had no access to the district-sponsored arts program.

In contrast, this divide was not present among the arts organizations' staff and teaching artists. They all showed a deep commitment to developing and providing quality arts programs. Despite working conditions that were far from ideal, particularly for the visual arts artists, the teaching artists loved working with the children and found satisfaction in their positions. Jean, a Valley Arts Studio (VAS) artist, felt that she helped students "stretch their brain and use their imagination." This finding contrasts with the MetLife Surveys of the American Teacher, which report a continuous and significant decline in job satisfaction since 2008. According to a 2012 study, only $39 \%$ of teachers were very satisfied with their job in 2012, a drop of $23 \%$ compared to the 2008 figure (MetLife, 2013).

Both the teaching artists and the arts organizations' staff had strong opinions about what a "good education" should be, and they viewed their roles as vital for keeping the arts in the schools. For Jim, a Center for the Arts (CftA) teaching artist, learning in the arts had many benefits: it developed students' creativity, offered additional ways to deepen their understanding of academic subjects, and taught students to be productive whether they were working alone or within a group. Moreover, the arts gave students a "sense of wholeness," which, he underlined, was "different than being happy." They helped children to be attuned to their feelings, to find ways within themselves to be calm, and to better understand the world in which they lived. Appreciating beauty and knowing "what deep joy is about" were important skills to have in today's world, which he 
described as a place "where so much is virtual and so much is high speed." He believed these skills were learned uniquely through the arts, and he considered it the arts educators' responsibility to demonstrate this value to teachers and school administrators, who often saw the arts as "frills."

Burdens and obstacles. The study's findings uncovered several ongoing challenges at the three research sites. Both the teachers and the teaching artists at Shadow Brook commented on the difficulties of working with a tight visual arts lesson schedule. Teachers noticed the fast pacing of the lessons had a negative effect on student learning, primarily in the lower grades. ELL students, in particular, struggled to understand instructions due to their limited grasp of English. The visual artists described persistent anxiety and stress due to back-to-back class schedules, and sharing their allocated classrooms with many other activities. At Shadow Brook, one or more instructors were in the room while the teaching artists taught their lessons. Sadie, a VAS teaching artist, never knew in what condition she would find the classroom when she arrived in the morning. On several occasions, she reported that the room she used (located at a school that was not part of the study) had no tables and chairs or, if they were in the room, all the furniture was stored along the walls.

Another source of stress for the visual arts teaching artists was the lack of time for preparation. Teaching artists of all disciplines required time to design the content of their lessons, but only visual artists needed additional time on site to prepare arts materials for each lesson they taught. Such preparation could amount to a considerable amount of time, depending on the type of media used on any given day. A typical day in the life of 
the visual artists I interviewed unfolded as follows: They arrived 45 minutes to an hour before their first class to set up the room and the materials for the day's activities; they cleaned up materials at the end of each class, and prepared them again for the next class. Their work continued through the lunch hour. The cleanup at the end of a day was as long as the morning set-up. Thus, materials preparation required as much or more time as teaching time. For example, Florence, the visual artist resident at Cypress, spent seven hours at school. Of these seven hours, only four hours were teaching time. In addition to the preparation time at the school site, she performed more tasks at home, such as purchasing materials online and at local stores, and she was expected to set up and take down two art shows. In all, she calculated that for the 40 hours of teaching time that made up her residency, she had spent a total of 152 hours, a ratio of material preparation time to teaching time of 3.8 to one. Table 12 shows an itemized list of all the tasks related to her teaching time. 
Table 12

Residency at Cypress: Comparing Preparation and Teaching

\section{Teaching time}

4 second grade classes; 1-hour session each week for 10 weeks

Arrives at school at 7:15-7:30 am - leaves school at 2:15-2:30 pm

7 hours spent at school each day of the residency

(4 hours of teaching, 3 hours of preparation time)

Teaching Time: $\mathbf{4 0}$ hours

Teaching Schedule: 8:10-9:10; 9:10-10:10;10:30-11:30;12:40-1:40

\begin{tabular}{|c|c|}
\hline Preparation Time & Hours \\
\hline Meeting with $2^{\text {nd }}$ grade team (pre- and mid-residency meetings) & 2 \\
\hline Extra session to finish last residency project & 4 \\
\hline $\begin{array}{l}\text { Re-writing and formatting } 6 \text { lessons with the new Center for the Arts' lesson } \\
\text { template }\end{array}$ & 18 \\
\hline Material preparation time at the school site (at least) & 33 \\
\hline $\begin{array}{l}\text { Material preparation time at home (at least } 3 \text { hours per session) } \\
\text { - Selecting materials in the morning and sorting the material when she } \\
\text { returns back home, washing materials (brushes, glue sticks, trays), cutting } \\
\text { construction paper, cutting paper to specific sizes } \\
\text { - } \quad \text { Preparing and printing lesson materials (pictures, working sheets) } \\
\text { - Sending and answering e-mails correspondence with teachers and CftA } \\
\text { - } \text { staff } \\
\text { Purchasing materials online or at local stores }\end{array}$ & 30 \\
\hline $\begin{array}{l}\text { Water poster project: checking that } 85 \text { students' work files were saved correctly on } \\
\text { the iPads and transferring each file to Florence's laptop (for printing) }\end{array}$ & 2 \\
\hline Format these files according to printing shop specifications & 6 \\
\hline Pick up printed posters at the shop & 1 \\
\hline Setting up school art show & 5 \\
\hline Time staffing the school art show & 3 \\
\hline Taking down school art show & 1 \\
\hline Driving time to and from school for setting up and taking down art show & 1 \\
\hline Setting up and taking down District STEAM showcase & 3 \\
\hline Time staffing the STEAM showcase & 3 \\
\hline Driving to and from STEAM showcase location & 1 \\
\hline Total hours of preparation & 116 \\
\hline
\end{tabular}

None of the visual artists had space to store materials at school, since they shared the classrooms with other instructors. As a consequence, they carried materials from home to school and back each day. By contrast, performing artists were easier to accommodate; they needed no preparation time on site. In term of physical space, they only required a 
room large enough for children to move comfortably. Despite these differing needs, the visual arts schedules were organized identically to performing arts schedules.

Several reasons could explain this oversight. One of them was that the organization of the arts residencies relied on two different institutions - the schools and the arts organizations - that may not have shared the same priorities. The schedules were the responsibility of the arts organizations, whereas the school staff was in charge of allocating the facilities. Creating the arts schedules was a complex task, as they must match the classrooms' schedules. For the staff in charge, it may have been convenient to consider all the arts disciplines together as one, in terms of scheduling, rather than as separate entities with distinct needs. Further, the person who organized the schedules, not being a visual artist him/herself, may not have been aware of those artists' needs.

All teaching artists, no matter their art discipline, must prepare for their residencies (for example, they need to create the art curriculum). However, the need for extensive material preparation time is unique to the visual arts and extremely time consuming, as demonstrated in the table above. Each arts organization included some preparation time into the remuneration of their artists, but it was unclear which specific services and for how many hours the salary was paid. While both organizations showed a concern with treating their artists equally, their compensation systems were not fair to the visual artists, since their specific need for material preparation was overlooked. Highlighting this difference is important as it underlines the larger issue of fairly remunerating all teaching artists. 
Inadequate facilities for arts programs. The school sites I studied were, for the most part, unable to provide adequate classroom space for the residencies. This was due to a growing student population and increasingly complex curriculum demands for physical space. Cypress, for example, was considering converting the multi-usage room allocated to the arts residencies into a Makerspace—a specific place designed for hands-on learning, particularly in science, technology, and engineering. These spaces are equipped with a variety of tools, including electronics equipment, 3-D printers, carpenter's tools, and sewing machines. Multiple demands for space made it more challenging for the school administrators to designate a specific place for the short-term arts programs. Moreover, the location of the classrooms allocated to the residencies were situated far from the other classrooms, contributing to keeping the arts programs at the periphery of the school life, and creating barriers for teaching artists and teachers to develop relationships (Purnell, 2004).

Artists' feeling of isolation. Visual arts teaching artists struggled with back-to-back classes and the continuous need for the preparation of materials. These circumstances severely limited their ability to socialize with the teachers and to participate in school life. The TAs reported they felt isolated, both in the school and in their profession, and were eager to meet with and share their classroom experiences with other arts educators, or to simply discuss their art curriculum with the classroom teachers. For example, Jean, one of the VAS visual artists at Shadow Brook, spoke about "snack day," a social event that occurred every Wednesday. Although a few teachers suggested she should go to the 
staff room to have some snacks and socialize, Jean never went. She felt she would not fit in at these events because she did not see herself as a member of the staff.

Consistency and continuity in the programs. Data revealed variations in the arts programs in both models of arts instruction. As teaching artists were contractors, there was no guarantee that the same teaching artists would return to the same schools each year, causing frequent changes in the arts curricula. This made it difficult for the Valley Arts Studio teaching artists to develop lessons that were aligned with the arts standards. Jean expressed her frustration at having to teach the concept of perspective to $5^{\text {th }}$ grade students $-\mathrm{a}$ standard set by the arts organization and that she was required to teach - who had not mastered basic techniques for creating the illusion of space that, according to the standards, should have been taught in earlier grades.

Consistency and continuity in the arts residencies were more challenging with the arts integration model, since the schools' academic curricula often changed, making the integrated arts lessons obsolete. The CftA artists, Florence and Jim, devised strategies to overcome these issues. Rather than being tied closely to classroom learning, Florence, the resident artist at Cypress, created lessons that focused on the importance of water and the consequences of human activity on the ocean and the Bay Area watershed. For her, addressing broad themes that connected to real-world problems would always be relevant, and raised students' awareness of the importance of caring for and protecting the environment in which they lived. Jim, the storyteller and drama teacher at Orchard, focused on teaching foundational skills, behaviorally (calming exercises) and artistically 
(utilizing tableaux to represent words and ideas), that could be adapted to any type of academic content.

Teacher-teaching artist relationship. A key finding of the study was that the teachers' participation in the art lessons varied considerably, depending on the model of arts instruction. In the stand-alone arts program, teachers did not participate at all, using art time to prepare for their own lessons. Few strong relationships had developed between teachers and teaching artists in the eight years the partnership had been in place at Shadow Brook. The teachers' unavailability encouraged students to act out, leaving teaching artists with the responsibility of resolving classroom management issues with students they hardly knew. Problems with discipline differed, however. This was a challenge at Shadow Brook, but not at Cypress or at Orchard, where the classroom teachers fully participated in the lessons and did all that they could to assist the TAs.

Another significant finding was that the arts integration model encouraged teachers to engage with the arts and "empowered them to step out of their comfort zone and look at something different" (Beate, Principal at Cypress). At Orchard, particularly, where the TA and the teachers had been working together for four years, the Center for the Arts' Teaching Artist Program was successful and thriving. A collegial relationship had developed over the years, allowing the teachers and the TA to co-create arts-integrated activities and to share the responsibility of leading the residency lessons. Once the residency ended, the teachers continued to use the teaching methods and arts techniques they had learned with the TA, adapting them to their classroom needs. 
However, for this genuine cooperation to take place, trust was required, plus an understanding of and respect for one another's expertise and responsibilities. While that type of relationship flourished at Orchard, that was not the case at Cypress, where finding the right TA-teacher match had been difficult, as evidenced by previous residencies the participants discussed. For example, one of the resident artists, a musician, taught lessons that focused on writing and performing songs. However, his lesson content did not connect to the classroom curricula at the time of the residency. This required the teachers to supplement the teaching artist curriculum, during non-art classroom time, to prepare students for the next lesson with the teaching artist. Karen expressed the general feeling of frustration she and her colleagues experienced: "We were doing a lot of work ourselves and not as much was coming from our artists."

In spite of several negative experiences, the Cypress teachers grew to appreciate the residencies, particularly after working with Florence. They valued her teaching methods and were able to connect the learning taking place in her lessons with the learning occurring in their own classrooms. They also learned to weave Florence's arts techniques into their classroom projects.

This finding is important and promising. While the literature establishes that teachers have strong attitudes and beliefs about their educational practices, making change difficult, (Richardson, 2003), this study provides evidence that it is possible. With the right conditions, relationships between teaching artists and school faculty can develop and flourish, inspiring teachers to think in new ways about the arts. Participants at Orchard and Cypress no longer saw the arts as stand-alone disciplines only, but as 
instructional strategies for deepening students' understanding and mastery of other academic content. Working alongside teaching artists encouraged the teachers to reflect on their own practices and then to try new approaches to teaching. In that aspect, this study aligns with previous research findings on arts integration, supporting the growing evidence that partnerships between teaching artists and classroom teachers have significantly positive effects on teachers' practices. According to Burton, Horowitz \& Abeles (1999) the longer teachers were exposed to arts-integrated learning, the more creative and innovative they became, and showed "considerable flexibility in curriculum design" (p. 41). In addition, teachers developed skills that enabled them to individualize instruction according to their students' learning needs (Burnaford, 2006).

As this study demonstrated, the teachers-teaching artist relationship was essential to successful arts integration. Since the stand-alone arts programs at Shadow Brook did not require teachers and teaching artists to collaborate, the limited relationships that existed between them had some negative consequences on students' arts experiences. Without the guidance of their teachers, children tended to act out, particularly in the upper grades. Lower grade teachers complained about the fast pace of the visual arts lessons, but they did not communicate their concerns to the TA, who was ignorant of the problem, and continued to teach as though the students had no difficulties understanding her directions. One might speculate that, had the teachers and the TA been given the opportunity to discuss the art curriculum, these ongoing challenges would have been quickly resolved.

Differing approaches. Another notable finding linked to those discussed above concerned relationship building and the classroom teachers' and TAs' perceptions of one 
another's roles within the partnerships. At Cypress, for example, the teachers felt that most of the TAs they had worked with expected them to give students extra time in class to finish their work when there was not enough time during the art lesson itself. The teachers saw these demands as unrealistic in view of their already-encumbered classroom schedule. They thought the teaching artists had little to no understanding of what their daily responsibilities were, and wished that the artists could visit and observe their classrooms so they would be better aware of "what our day is like" (Heidi, teacher at Cypress)

Literature describes the relationship between the classroom teacher and the teaching artist as the "foundation" of the partnership (Myers, 2001, p. 8) and as "the most important dynamic of the partnership if any significant and enduring learning is to take place" (Remer, 1996, p. 231). The same literature points out that teachers' and artists' experiences and beliefs belong to different professional cultures, which can be a significant challenge to building relationship. Remer described the school as an environment that is "rules-oriented" and "time-dominated," valuing conformity, the right answer, and convergent thinking (p. 231). In such an environment, teachers are pressed to produce results. In comparison, artists' work centers on personal expression, open-ended processes, and original thinking, with little consideration for time limitations (Chemi, 2014). Through the arts partnerships, both parties can learn a great deal from one another, provided they have opportunities to know each other better. As teachers and teaching artists spend more time together, they would be enabled to appreciate their differences 
and to utilize these differences to create a community of learning that would benefit not only the children, but everyone involved in the relationship.

None of the partnerships analyzed in this study had put in place a structure that would facilitate these conversations and allocate time for cooperation and teamwork. Even at Orchard, where the partnership was the most successful, teachers and TA had no set time in their schedules for collaborative planning; the only time they could meet was during the teachers' lunch time. Thus, the success of the partnerships, particularly at Orchard and Cypress, rested less on a support structure, but more on the willingness and dedication of both the teaching artists and the teachers. Despite being extremely busy with school demands, all involved clearly wanted the partnerships to succeed.

Different models of arts instruction. This study investigated two types of arts partnerships, each of which provided a distinct model of arts instruction. The Valley Arts Studio - Shadow Brook partnership provided stand-alone arts programs that were entirely designed by the arts organization and the teaching artists, with no input from the school. By comparison, the Center for the Arts partnerships at Cypress and Orchard focused on arts integration and relied upon collaboration between teaching artists and classroom teachers in order to develop curricula that met the schools' needs.

While the data analysis compared the two models of arts instruction, the study's intent was not to place them in opposition, or to imply a preference for one mode of delivery over the other. On the contrary, the two models complement each other, and both have a rightful place in the school curriculum. Direct instruction (teaching art for arts' sake) develops students' artistic and aesthetic abilities by exposing them to arts 
history and studio art techniques. Arts integration, on the other hand, is woven into the classroom curriculum, so the arts are "a natural part of how the content is presented" (Donovan \& Pascale, 2004, p. 17). While each model has its own objectives, each has positive outcomes and contributes to enriching students' learning experiences (Aprill, 2010).

However, there is a divide among arts educators as to which model of arts instruction best serves student learning in the arts and advances the cause of arts education. Proponents of teaching art for arts' sake are concerned that connecting arts disciplines to other academic subjects relegates the study of the art forms to a secondary role (McKean, 2001, p.28) and diminishes the quality of artwork produced (Aprill, 2010). Supporters of arts integration argue that using the arts to teach academic subjects is likely to solidify the presence of the arts in the classrooms (Gadsden, 2008). Moreover, they contend that high-quality arts integration identifies learning goals in both the art form and the non-arts subject, resulting in artwork that is "conceptually compelling and aesthetically sophisticated" (Aprill, 2010, p. 7).

Reflecting on her approach to creating curricula, Florence, the teaching artist who integrated visual arts and science at Cypress, acknowledged that she tended to design lessons around the science component rather than around an art concept. Further, rather than considering what specific arts standards she needed to address in each of her lessons, she chose art techniques that would most successfully reach her learning objectives. She gave several reasons for taking this approach. The limited time she had with the students (a total of only ten hours per year) made it difficult to set learning goals in both 
disciplines; as a result, she had to prioritize one discipline over the other. She saw a benefit in this method: focusing on the science content enabled the teachers to fully engage in the lessons. They were less intimidated by the "art aspect of the lessons," and thus could, "through basic knowledge, enter the conversation with the kids."

While Florence's way of designing content had a positive effect on teachers, it also meant that children did not receive visual arts instruction that was as thorough as it might have been. This dilemma seemed inevitable due to time constraints and the fact that teaching artists bore the sole responsibility of creating the residency lessons. The necessity of making such choices puts teaching artists at the heart of the debate between proponents and opponents of arts integration.

Teaching the arts should not be confined to the art or music room, as art is everywhere and connects to all domains of knowledge. The arts are vehicles for critically expressing concepts of personal and social identity, history, science, and language (Aprill, 2010), that is, concepts of human life. This study supports Dewey's (2005/1934) theory that art functions as experience, i.e. artistic expression must be understood through the experience of the artist that created it and within the context in which it was created, rather than being solely appreciated as an end product. An ideal model of arts education is one that offers direct instruction in the arts and connects this instruction to other domains of knowledge. In such model, both the art(s) discipline(s) and the non-art subject(s) are treated and taught equally, allowing students to become art-knowledgeable (that is, to develop craft and aesthetics) and to gain a deeper understanding of the non-art subjects through their experience of making or performing an art form. For this to occur, 
it is essential that classroom teachers and teaching artists work as a team to foster integrated teaching and learning, since each person has expertise the other does not possess. It is only by combining the two that the schools can create an arts-rich environment in which students not only acquire fact-based knowledge, but have the opportunities to receive the most complete learning experiences possible.

Role of arts partnerships. This study calls attention to the larger issue of arts education practices in elementary schools. In spite of federal and state policies defining the visual and performing arts as essential to a comprehensive education and the growing evidence of their benefits, schools fail to provide full instruction in the arts. Limited budgets and increased accountability have forced schools to focus on the academic subjects that are evaluated through standardized tests, thus keeping the teaching of the arts at the periphery of the curriculum. In that context, schools have turned to arts organizations and artists to provide arts education, rather than building teachers' capacities and confidence in integrating arts learning into their instruction. (McKean, 2001, p.23)

As arts partnerships are taking a prominent role in sustaining arts programs in elementary schools, the question of the content of these programs arises. One cannot help but wonder, for example, if the VAS model, albeit taught by knowledgeable and professional artists and well appreciated by the Shadow Brook staff and faculty, has a lasting impact on student learning. Do so few hours of arts instruction (four hours and thirty minutes of visual arts and three hours in each of the performing arts disciplines, that is, a total of 13.5 hours per year) go beyond a superficial exposure to the arts and 
deeply change students' learning experiences? It seems that the issue at hand is not whether arts instruction should be taught separately from or integrated with non-arts subjects. Rather, the question to be examined should be about the content of these arts programs and how to implement them so they best serve the needs of students.

\section{Recommendations}

Based on the study findings, several recommendations can be made to ensure these partnerships are successful and thrive. Some are specific to the model of arts instruction — stand-alone arts instruction or arts-integrated lessons — or to the position of the individuals involved. Others address general issues that are relevant to both models of partnerships.

Public schools: Engage school and district leaders with the arts. The administrators I interviewed stressed the importance of arts education and spoke of how it positively affected their students. However, the Shadow Brook principal, for example, added that arts instruction was given low priority at her school because academic subjects were more important. School leaders must believe in the power of the arts to change student learning experiences for the better. They must be actively involved and willing to commit time and effort to foster an environment in which the arts are seen as indispensable to a child's education. In order to increase their interest in the arts and their motivation to foster an arts-rich school culture, there are several small steps leaders could take. For example, they could attend lectures or conferences on arts learning, read literature on the benefits of arts education, or attend professional development in the arts. Additionally, visiting neighboring schools that have successfully integrated teaching and 
learning in the arts could help leaders to design art plans that would effectively address their schools' needs.

Public schools: Engage teachers with the arts. As demonstrated in this study, teachers' participation is also essential to guarantee successful implementation of arts programs. While they are unlikely to become arts experts, they would greatly benefit from participating in professional development sessions that center on arts practices. These sessions would increase teachers' understanding of how the arts can be infused into the curriculum. Hands-on workshops, particularly, would offer a safe environment in which teachers can learn and practice arts techniques. These workshops would have more impact if they were designed according to specific requests from the teachers.

Public schools: Designate art space. Schools are overpopulated and space is in short supply. Since arts residencies do not take place all year, it is easy to for administrators to overlook the specific needs of the arts programs. However, as schools enter a partnership, they must be made aware that they have a responsibility to provide adequate space for such activities. Likewise, arts organizations should clearly articulate the needs of the teaching artists, particularly for the visual arts, and make meeting these needs a condition of the partnership.

Public schools: Extend the residency periods. Schools and arts organizations should consider expanding arts partnerships to the entire school year. Year-long residencies would give the arts a more prominent place in the schools' curricula and have a greater impact on student learning. Further, extending residencies through the school year would make the allocation of a permanent space for these programs a primary 
concern for the schools. As a possible consequence of creating an arts space, the position of the arts as core subjects would be strengthened.

Public schools: Set up time for teacher-teaching artist collaboration. Schools leaders should create an environment that facilitates teachers and teaching artists' dialogue, thereby fostering effective working relationships. To that end, planning sessions should be scheduled not only during the residencies, but also regularly throughout the school year, so teachers and teaching artists have more opportunities to meet, to understand how to work together, and to find new avenues for arts instruction in the classroom. In parallel with planning sessions, schools and arts organizations, together, should organize professional development sessions, in which teachers and teaching artists can practice co-leading arts-integrated activities in a safe setting that allows for trial and error.

\section{Arts organizations and teaching artists: Articulate the visual artists' needs.}

Visual artists need to be explicit about their needs, and communicate them to arts organizations' staff. The teaching artists' contracts should clearly define 1) the preparation time for designing lesson content; 2) the delivery time for the lessons; and 3) the preparation time for arts materials set-up and clean-up and for purchasing supplies, if the teaching artist is responsible for this task; and 4) any other tasks or responsibilities associated with the residency. These adjustments would avoid the stress of a back-toback class schedule and ensure that teaching artists are paid appropriately. Further, improved work conditions may encourage more visual artists to become teaching artists. 


\section{Arts organizations and teaching artists: Provide artist training. Arts}

organizations must be responsible for adequately preparing their artists for teaching in the school environment. They should provide training sessions in a variety of topics, including classroom management techniques, pedagogy methods, and lesson planning. These organizations should facilitate teaching artists' visits to classrooms so they better understand the teachers' daily responsibilities. Furthermore, observing the teachers with whom they work would give the TAs insights into the teachers' instructional styles, how they pace their lessons, and what types of behavior they expect from the students. In addition to providing training, a support system should be put in place to supervise and evaluate arts residencies, which would guarantee the quality of the programs and provide teaching artists with mentors. Another step toward building effective, stable partnerships with the schools would be to consider hiring artists as employees, so they would be more likely to remain in the same schools. This would also offer job security.

Recommendations for colleges and universities. Another avenue for building awareness of the power of the arts would be to include arts education courses in administrators' and teachers' training programs. Administrative candidates' participation in arts courses would deepen their understanding of 1) the cognitive processes involved in art-making and art-performing activities and 2) how arts integration enhances classroom learning. This knowledge may empower school leaders to create a supportive environment for the arts that would facilitate the development and implementation of arts programs. In doing so, teachers may be encouraged to infuse arts learning into their classrooms. 
In the same vein, teacher preparation programs should include an art component. The art curriculum should encompass 1) Arts studio learning (i.e. acquiring a basic foundational training in the arts through individual and group arts-making and artsperforming experiences); 2) arts methods courses centered on arts integration strategies; and 3) courses that would develop student teachers' collaboration and communication skills in order to prepare them for working with teaching artists to create crossdisciplinary curriculum. Through this university training, teachers would develop the confidence to interact with the arts and appreciate the value to utilizing them as tools for teaching other subjects.

Recommendations for policy makers. The state of California has enacted policies that define the arts as core subjects and adopted visual and performing arts standards since 2001; its education code mandates elementary schools incorporate arts instruction in dance, music, theatre, and the visual arts. However, no policies are in place to ensure that the schools are accountable for providing standard-based instruction, or to assess student learning in the arts. As a result, the decision to implement arts programs is left to the discretion of school and district leaders. The partnerships examined in this study demonstrate that when teachers and teaching artists work together, the collaboration that ensues gradually changes teachers' views and beliefs with regard to arts instruction, which they come to see as instructional tools to help children better understand academic content. It is important to take this organic process into account when implementing reforms. In order to change habits and practices, people must believe in the good of that change. While policies are necessary to support reforms, a shift in school culture toward 
the arts will more likely occur organically than from top-down decisions or from mandates. That being said, the state has an important role to play in supporting arts education. It should put in place policies that hold the schools accountable for providing arts programs, but more importantly, it should appropriate additional funding for schools to implement such programs.

Recommendations for future research. The present study focused on arts education partnerships in elementary schools situated in urban areas, where arts organizations are plentiful. However, such partnership opportunities may not be available in less populated or rural areas. An avenue for future research would be to investigate arts education practices in California public schools statewide in order to determine the presence (or absence) of arts programs and the conditions under which these programs are provided. Only one study on this scale was conducted, in 2005-2006 (Woodworth et al., 2007). Replicating this study would reveal new data that could be compared to the previous findings and shed light about the present state of arts education. Questions to be answered might include: How many arts programs currently exist in California schools compared to ten years ago? Do students in California have equal access to arts programs? How does arts education in California compare to arts education in other states? The data collected would make it possible to create a visual map of arts education programs across the state, and would highlight geographic areas where arts education is missing. In addition, such studies may identify populations of students who have limited or no access to arts programs. Further, research could examine other states that are more successful in maintaining arts programs, particularly at the elementary level. For example, one might 
look at the policies and incentives these states have established to guarantee schools and districts comply with these policies. All this data would be valuable to California policy makers to enact and implement better laws that support arts education.

Another area of interest for future research would be to evaluate arts programs at the elementary level and determine the most viable delivery method, that is, who should bear the responsibility of teaching the arts. Should the schools build their teachers' capacities to teach the arts? Should arts education continue to be provided by outside arts organizations? What type of funding would be needed to sustain each model? Additional studies could look at how teacher-teaching artist collaboration should be structured so it is the most effective. What resources and support systems do teachers and teaching artists need in order to create a dynamic, learner-centered culture that benefits not only the students but the adults, as well, contributing to their professional growth?

Last, another avenue for future research would be to evaluate the impact of arts education on student learning. While the number of studies in that field is growing, most of these studies are isolated and small-scale. More data is needed to better understand the ways in which the arts can contribute to student success. Designing large-scale studies that compare students exposed to the arts with control groups would raise awareness of their potential for deepening student learning experiences. Examining whether participation in the arts could increase student engagement with their studies, potentially decreasing absenteeism and dropouts, would also be of use for school leaders. 


\section{References}

Aprill, A. (2010). Direct instruction vs. arts integration: A false dichotomy. Teaching Artist Journal, 8(1), 6-15. doi:10.1080/15411790903393004

Art Education Partnership (n.d.). Mission/Overview. Retrieved from http://www.aeparts.org/about-aep/missionoverview/

Arts Education Partnership (2004). No subject left behind: A guide to arts education opportunities in the 2001 NCLB Act. Retrieved from http://www.aep-arts.org/nochild-left-behind-resources/

Arts Education Partnership (2014). A snapshot of state policies for arts education. Retrieved from http://www.aep-arts.org/research-policy/artscan/research-policybriefs/

Arts Education Partnership (2016). States of the states: Arts education state policy summary. Retrieved from http://www.aep-arts.org/research-policy/artscan/stateof-the-states-2015/

Arts Impact (n.d.). Arts Impact Dissemination and Expansion Final Report. Retrieved from https://arts-impact.org/research-projects/arts-impact-dissemination-andexpansion/

$\mathrm{Au}, \mathrm{W}$. (2007). High-stakes testing and curricular control: A qualitative metasynthesis. Educational Researcher, 36(5), 258-267.

Baker, R. A. (2012). The effects of high-stakes testing policy on arts education. Arts Education Policy Review, 113(1), 17-25. doi:10.1080/10632913.2012.626384

Bamford, A. (2010). Issues of global and local quality in arts education. Encounters on education, 11, 47-66.

Berliner, D. (2011). Rational responses to high stakes testing: the case of curriculum narrowing and the harm that follows. Cambridge Journal of Education, 41(3), 287-302. doi:10.1080/0305764X.2011.607151

Beveridge, T. (2010). No Child Left Behind and Fine Arts Classes. Arts Education Policy Review, 111(1), 4-7. 
Bodilly, S. J., Augustine, C. H. \& Zakaras, L. (2008). Revitalizing arts education through community-wide coordination. Santa Monica, CA: Rand Corporation. Retrieved from

http://www.rand.org/content/dam/rand/pubs/monographs/2008/RAND_MG702.p df

Brouillette, L. (2010). How the arts help children to create healthy social scripts: Exploring the perceptions of elementary teachers. Arts Education Policy Review, $111(1), 16-24$.

Brouillette, L. (2012). Supporting the language development of limited English proficient students through arts integration in the primary grades. Arts Education Policy Review, 113(2), 68-74.

Burton, J., Horowitz, R. \& Abeles, H. (1999). Learning in and through the arts: Curriculum implications. In Fiske, E. B. (Ed), Champion of change: The impact of arts on learning (pp. 35-46). Washington, DC: Arts Education Partnership and the President's Committee on the Arts and the Humanities.

Burnaford, G. (2006). Moving toward a culture of evidence: Documentation and action research. Retrieved from Chicago Arts Partnerships in Educations (CAPE) website: http://capechicago.org/our-publications/

California Arts Council (n.d.). Mission, Vision, Values. Retrieved from http://www.cac.ca.gov/aboutus/mission.php

California Arts Council (2016, June 28). California state budget includes increase investment in the arts [Press release]. Retrieved from http://www.cac.ca.gov/news/prdetail.php?id=233

California County Superintendents Arts Initiative, (n.d.). Creativity at the Core. Retrieved from http://ccsesaarts.org/creativity-at-the-core/

California County Superintendents Educational Services Association (n.d.). Leadership in the arts and Common Core standards [Handout]. Retrieved from http://ccsesaarts.org/wp-content/uploads/2014/11/Mod12_HandoutPart2_1.pdf

California Department of Education (2001). California Education Code, Section 51210. Retrieved from http://leginfo.legislature.ca.gov/faces/codes_displaySection.xhtml?lawCode=EDC \&sectionNum $=51210$ 
California Department of Education (2004). 2006-2007. Visual and performing arts framework for California public schools: Kindergarten through grade twelve. Sacramento, CA: CDE Press.

California Department of Education. (2013). The joint arts education task force report: How the arts and creative education can transform California's classrooms. Retrieved from http://cac.ca.gov/files/CREATE-TaskForceReport.pdf

CREATE CA (2015). A blueprint for creative schools. Retrieved from https://www.cde.ca.gov/eo/in/documents/bfcsreport.pdf

Carlisle, K. (2011). Arts education partnerships: Informing policy through the development of culture and creativity within a collaborative project approach. Arts Education Policy Review, 112(3), 144-148.

doi:10.1080/10632913.2011.566088

Catterall, J.S. (2009). Doing well and doing good by doing art. Los Angeles, CA: imagination Group/I-group Books.

Catterall, J.S., Dumais, S.A. \& Hamden-Thompson, G. (2012). The Arts and achievement in at-risk youth: Findings from four longitudinal studies. National Endowment for the Arts, Research Report \#55. Washington, DC: National Endowment for the Arts. Retrieved from http://arts.gov/sites/default/files/Arts-At-Risk-Youth.pdf

Catterall, J.S., \& Waldorf, L. (1999). Chicago arts partnerships in education: Summary evaluation. In Fiske, E. B. (Ed.). Champions of change: The impact of the arts on learning (pp. 47-62). Washington, DC: Arts Education Partnership and The President's Committee on the Arts and the Humanities.

CBS News (2013, February 8). Calif. Gov. Jerry Brown: Prop 30 a "tough battle." Retrieved from https://www.cbsnews.com/news/calif-gov-jerry-brown-prop-30-atough-battle/

CBS News (2012, November 12). High stakes for California Prop. 30 election day decision. Retrieved from http://www.cbsnews.com/news/high-stakes-for-califprop-30-election-day-decision/

Chapman, L. H. (2004). No child left behind in art? Arts Education Policy Review, $106(2), 3-20$.

Charmaz, K. (2014). Constructing grounded theory, $2^{\text {nd }}$ Edition. Thousand Oaks, CA: Sage Publications, Inc. 
Chemi, T. (2014). The artful teacher: A conceptual model for arts integration in schools. Studies in Art Education, 56(1), 370-383.

Cleary Dale, L. (2016, April 06). Arts education is not a luxury. It is a necessity [Web blog post]. Retrieved from https://blog.americansforthearts.org/2016/04/06/artseducation-is-not-a-luxury-it-is-a-necessity

Coleman, D. (2013). Guiding principles for the arts Grades K-12. New York State Education Department. Retrieved from http://usny.nysed.gov/rttt/docs/guidingprinciples-arts.pdf

Colley, B. D. (2008). Partnerships and local K-12 Arts education policy development: Significant beginnings. Arts Education Policy Review, 109(5), 9-18.

Creswell, J. W. (2013). Qualitative enquiry \& research design: Choosing among five approaches, $3^{\text {rd }}$ Edition. Thousand Oaks, CA: Sage Publications, Inc.

Dewey, J. (2005). Art as experience. New York, NY: Penguin Group. (Original work published 1934)

Dreeszen, C. (1992). Intersections: Community arts and education collaborations (Report No ISBN 0945-464096). Amherst, MA: University of Massachusetts Amherst

Donovan, L. \& Pascale. L. (2013). Integrating the arts across the content areas. Huntington Beach, CA: Shell Education.

Duma, A. (2014). A view into a decade of arts integration. Journal For Learning Through The Arts, 10(1).

Editorial Projects in Education Research Center. (2011, July 7). Issues A-Z: Achievement Gap. Education Week. Retrieved from http://www.edweek.org/ew/issues/achievement-gap/

Efland, A.D. (2002). Art and cognition: Integrating the visual arts in the curriculum. New York, NY: Teacher College Press.

Eisner, E.W. (2002). The arts and the creation of the mind. New Haven, CT: Yale University Press.

Elementary and Secondary Education Act of 1965, P.L. 89-10 (2015). 
Eger, J.M. (2015). California in the creative economy: Arts education, innovation and a revolution waiting to happen. Retrieved from http://www.createca.net/wpcontent/uploads/2014/03/California-in-the-Creative-Economy_11-2015.pdf

Every Student Succeeds Act of 2015, P.L. 114-95, 20 U.S.C. (2015).

Fiske, E. B. (Ed.). (1999). Champion of change: The impact of the arts on learning. Washington, DC: The Arts Education Partnership and The President's Committee on the Arts and the Humanities.

Fowler, C. (1996). Strong arts, strong schools. New York, NY: Oxford University Press.

Freedman, K. (2007). Artmaking/troublemaking: Creativity, policy, and leadership in art education. Studies in Art Education, 48(2), 204-217.

Freeman, C., Seashore, K., Werner, L. (2003). Models of implementing Arts for Academic Achievement: Challenging contemporary classroom practice. Center for Applied Research and Educational Improvement. Retrieved from the University of Minnesota Digital Conservancy, http://hdl.handle.net/11299/143831.

Gadsden, V. L. (2008). The Arts and education: Knowledge generation, pedagogy, and the discourse of learning. Review Of Research In Education, 32(1), 29-61.

Goff, R., \& Ludwig, M. (2013). Teacher practice and student outcomes in arts-integrated learning settings: A review of literature. Washington, DC: American Institutes for Research. Retrieved from http://www.wolftrap.org/education/institute_for_early_learning_through_the_arts/ $\sim /$ media/8db86a897dbb4d228943e0e3cea04aeb.ashx

Guha, R., Kim, D., Malin, H., Park, J., \& Woodworth, K. R. (2008). Un unfinished canvas: A look at teacher preparation, delivery of instruction, and professional development. Menlo Park, CA: SRI International. Retrieved from http://www.hewlett.org/uploads/files/UnfinishedCanvasArtsTeacherCapacityRepo rtSRI.pdf

Heath, S. B. (2014). The foundational bases of learning with the arts. The Educational Forum, 78 (4), 358-362. doi: 10.1080/00131725.2014.944078

Heath, S. B., Soep, E., \& Roach, A. (1998). Living the arts through language+ learning: A report on community-based youth organizations. Washington, DC: Americans for the Arts. Retrieved from http://www.americansforthearts.org/sites/default/files/Living\%20the\%20Arts\%20 Through\%20Language\%20and\%20Learning\%20\%28November\%20\%2798\%29_ $0 . p d f$ 
Hetland, L., \& Winner, E. (2001). The arts and academic achievement: What the evidence shows. Arts Education Policy Review, 102(5), 3-6.

Hetland, L., Winner, E., Veenema, S., \& Sheridan, K., (2013). Studio Thinking 2: The real benefits of visual arts education. New York, NY: Teacher College Press.

Hoffmann Davis, J. (2008). Why our schools need the arts. New York, NY: Teachers College Press.

Horowitz, R. (2004). Summary of large-scale arts partnership evaluations. Washington, DC: Arts Education Partnership. Retrieved from http://209.59.135.52/files/evaluation/LargeScaleEvaluationReport.pdf?PHP

Ingram, D., \& Seashore, K. (2003). Arts for Academic Achievement: Summative evaluation report. Center for Applied Research and Educational Improvement. Retrieved from the University of Minnesota Digital Conservancy: http://hdl.handle.net/11299/143655

Jensen, E. (2001). Arts with the brain in mind. Alexandria, VA: ASCD.

Jones, S. D. \& Workman, E. (2016). ESSA's well-rounded education (Policy Report). Retrieved from Education Commission of the States website: https://www.ecs.org/ec-content/uploads/ESSAs-Well-Rounded-Education-1.pdf

Johnson, R. B., \& Onwuegbuzie, A. J. (2004). Mixed methods research: A research paradigm whose time has come. Educational researcher, 33(7), 14-26.

Kagan, J. (2009, May 6). Six good reasons for advocating the importance of the arts in schools. Keynote Speech presented at the Learning, Art, and the Brain conference in Baltimore, MD. Retrieved from http://dana.org/News/Details.aspx?id=42948

Klein, A. (2016, March 31). The Every Student Succeeds Act: An ESSA overview. Education Week. Retrieved from https://www.edweek.org/ew/issues/everystudent-succeeds-act/index.html

Lasdon-Billings, G. (2006). From the achievement gap to the education debt: Understanding achievement in U.S. schools. Educational Researcher, 35(7), 3-12.

Lynch, M. (2015, January 5). 7 ways Michelle Obama positively influenced education in 2014 [Web blog post]. Retrieved from https:/www.huffingtonpost.com/matthewlynch-edd/7-ways-michelle-obama-pos_b_6417060.html

McKean, B. (2001). Concerns and considerations for teacher development in the arts. Arts Education Policy Review, 102(4), 27-32. 
Marche, S. (2015, April 12). Is culture just for rich kids now [Web blog post]. Retrieved from https://www.huffingtonpost.com/stephen-marche/is-culture-just-for-richkids-now_b_6652006.html

Melnick, S. A., Witmer, J. T., \& Strickland, M. J. (2011). Cognition and student learning through the arts. Arts Education Policy Review, 112(3), 154-162. doi:10.1080/10632913.2011.566100

MetLife (2013). The MetLife survey of the American teacher: Challenge for school leadership. Retrieved from https://www.metlife.com/about/corporateresponsibility/metlife-foundation/reports-and-research/survey-americanteacher.html

Miller, R., Wake, D. \& Whittingham (2016). Implementation of the A+ schools program: An examination of baseline teacher perceptions and instructional behaviors. Journal of Interdisciplinary Studies in Education, 4(2), 3-22.

Myers, D. (2001). Excellence in Arts Teaching and Learning: A Collaborative Responsibility of Maturing Partnerships. 2001 Fowler Colloquium Papers. College Park, MD: University Libraries, University of Maryland. Retrieved from https://www.lib.umd.edu/binaries/content/assets/public/scpa/2001-myers.pdf

National Art Education Association (2016). ESEA reauthorization is finalized as Every Student Succeed Act (ESSA). National Art Education Association News, 58(1), 89.

National Coalition for Core Arts Standards (2017). The status of arts standards revision in the United States since 2014. Retrieved from http://www.nationalartsstandards.org/content/resources

No Child Left Behind Act of 2001, P.L. 107-110, 20 U.S.C. (2002).

Parsad, B., and Spiegelman, M. (2012). Arts education in public elementary and secondary schools: 1999-2000 and 2009-10 (NCES 2012-014). Washington, DC: National Center for Education Statistics, Institute of Education Sciences, U.S. Department of Education.

Peppler, K. A., Powell, C. W., Thompson, N., \& Catterall, J. (2014). Positive impact of arts integration on student academic achievement in English language arts. The Educational Forum (Vol. 78, No. 4, pp. 364-377). doi: 10.1080/00131725.2014.941124 
Poulin, J. (2014, June 04). What you need to know about the new National Core Arts Standards [Web blog post]. Retrieved from https://blog.americansforthearts.org/2014/06/04/what-you-need-to-know-aboutthe-new-national-core-arts-standards

President Committee on the Arts and Humanities (n.d.). Turnaround Arts initiative: Summary of findings. Retrieved from http://pcah.gov/sites/default/files/Turnaround\%20Arts\%20Phase\%201\%20Final\% 20Evaluation_Summary.pdf

President Committee on the Arts and Humanities (2011). Reinvesting in arts education: Winning America's future through creative schools. Retrieved from https://pcah.gov/sites/default/files/PCAH_Reinvesting_4web_0.pdf

Pruitt, L., Ingram, D., \& Weiss, C. (2014). Found in translation: Interdisciplinary arts integration in project AIM. Journal for Learning through the Arts, 10(1), 1-20.

Purnell, P. (2004). A place for the arts: The past, the present and teacher perceptions. Teaching Artist Journal, 2(3), 153-161.

Rabkin, N. (2012, December 6). Teaching artists and the future of the arts [Web blog post]. Retrieved from https://www.huffingtonpost.com/nick-rabkin/art-artistseducation_b_2239324.html

Rabkin, N., \& Redmond, R. (2006). The Arts make a difference. Educational Leadership, 63(5), 60-64.

Remer, J. (1996). Beyond enrichment: Building effective partnerships with schools and your community. New York, NY: American Council for the Arts.

Remer, J. (2010). From lessons learned to local action: Building your own policies for effective arts education, Arts Education Policy Review, 111, 81-96. doi:10.1080/10632911003626879

Richardson, V. (2003). Preservice teachers' beliefs. In Rath, J. \& McAinch,A.C. (Eds), Teacher beliefs and classroom performance: The impact of teacher education (pp. 1-22). Greenwich, CT: Information Age Publishing.

Riessman, C.K. (2008). Narrative methods for the human sciences. Thousands Oaks, CA: Sage Publications, Inc.

Robinson, A. H. (2013). Arts integration and the success of disadvantaged students: A research evaluation. Arts Education Policy Review, 114(4), 191-204. doi:10.1080/10632913.2013.826050 
Rowe, M. K., Werber Castaneda, L., Kaganoff, T. \& Robyn, A. (2004). Arts education partnerships: Lessons learned from one school district's experience. Santa Monica, CA: RAND Corporation.

Scripp, L., \& Paradis, L. (2013). Meeting the burden of proof: Statistical evidence for the impact of arts integration based on causal links among teacher professional development, arts learning and academic outcomes. Retrieved from Chicago Arts Partnerships in Educations (CAPE) website: http://capechicago.org/ourpublications

Seidel, S. (2000). Arts survive!: A study of sustainability in arts education partnerships [Executive Summary]. Cambridge, MA: Project Zero, Harvard Graduate School of Education. Retrieved from http://www.pz.harvard.edu/sites/default/files/Arts\%20Survive\%20Exec\%20Sum mary.pdf

Silverstein, L. B. \& Layne, S. (2010). Defining arts integration. The John F. Kennedy Center for the Performing Arts. Retrieved from http://www.kennedycenter.org/education/partners/defining_arts_integration.pdf

Sousa, D. A. (2006). How the arts develop the young brain. School Administrator, 63(11), 26-31.

Stark, J. L. (2014). The Potential of Deweyan-inspired action research. Education \& Culture, 30(2), 87-101. doi:10.1353/eac.2014.0013

Stake, R. E. (2010). Qualitative research: Studying how things work. New York, NY: Guilford Press.

State Education Agency Directors of Arts Education (n.d). National Arts Education Data Project. Retrieved from https://www.artseddata.org

Strauss, V. (2009, November 23). Willingham: Six practical reasons arts education is more than a luxury. The Washington Post. Retrieved from http://voices.washingtonpost.com/answer-sheet/arts-education/willingham-sixpractical-reaso.html

Waldorf, L. \& Atwill, K. (2011). Arts for all school arts survey: Measuring quality, access and equity in arts education. Los Angeles County Arts for All. Retrieved from http://lacountyartsforall.org/about-arts-for-all/publications 
Winner, E. \& Hetland, L. (2007, September 2). Art for our sake. The Boston Globe. Retrieved from http://archive.boston.com/news/globe/ideas/articles/2007/09/02/art_for_our_sake/

Woodworth, K. R., Gallagher, H. A., Guha, R., Campbell, A. Z., Lopez-Torkos, A. M., \& Kim, D. (2007). An unfinished canvas: Arts education in California, taking stock of policies and practices. Menlo Park, CA: SRI International. Retrieved from https://www.sri.com/work/publications/unfinished-canvas-arts-educationcalifornia-taking-stock-policies-and-practices

Woodworth, K. R., Petersen, D. M., Kim, D. H., \& Tse, V. (2009). An unfinished canvas: Local partnerships in support of arts education in California. Menlo Park, CA: SRI International. Retrieved from https://www.sri.com/work/publications/unfinished-canvas-local-partnershipssupport-arts-education-california

Yin, R. (2014). Case study research: Design and methods, $5^{\text {th }}$ ed. Thousand Oaks, CA: Sage Publications, Inc.

Zubrzycki, J. (2016, August 12). States move toward standardized arts tests [Web blog post]. Retrieved from http://blogs.edweek.org/edweek/curriculum/2016/08/arts_standardized_tests_asse ssing.html 
Appendix A

Participant Consent

\author{
San Jose State University \\ REQUEST FOR YOUR PARTICIPATION \\ IN RESEARCH STUDY INFORMATION SHEET \\ (For classroom teachers and teaching artists)
}

\title{
Sustaining Arts Education Partnerships in California Elementary Schools
}

\author{
Marie-Hélène Bauguil \\ Principal Investigator \\ Megan Thiele, Ph.D. \\ Arnold Danzig, Ph.D. \\ Faculty Advisor \\ Faculty Advisor
}

\section{PURPOSE}

This project looks at arts education in elementary schools, specifically when it is provided through partnerships with local arts organizations. This study investigates how these partnerships work on an everyday basis and the challenges they face to succeed and thrive.

The researcher, Marie-Helene Bauguil, is a graduate student at San Jose State University, conducting research for a doctoral degree in Educational Leadership.

You are invited to participate in this study because Orchard Elementary is providing arts instruction via a partnership with The Center for the Arts.

\section{PROCEDURES}

This study involves individual and groups interviews, and classroom observations. If you agree to participate in this study, the following will occur:

- You will be asked to participate in one group interview and/or a one-on-one interview about Orchard Lane Elementary arts partnership with The Center for the Arts. Each interview will last for approximately one hour and will be audiotaped to ensure accuracy in reporting your comments.

- The interviews will take place at your school, at a time convenient for you. 
- The researcher will also conduct classroom observations when the teaching artist is present in the classroom; this will follow the focus group/one-on-one interview sessions. During the observation, the researcher will take field notes and may take photographs of student's work and other art displays.

- The researcher may contact you later to clarify your interview comments, answers or her observation notes; this follow-up discussion will last for approximately fifteen to thirty minutes. Such conversations will be conducted via e-mail or telephone.

- The total time commitment will be approximately one hour and a half if you participate in only one type of interview (group or one-on-one), and about two hours if you agree to participate in both a group and a one-on-one interview.

\section{POTENTIAL RISKS}

A foreseeable risk associated with this study is the loss of privacy. However, pseudonyms, carefully chosen to protect anonymity, will be used in any published report of the research.

Because the focus group may include discussions of personal opinions, special measures will be taken to protect each participant's privacy. The focus group will begin with the researcher's explanation of the importance of maintaining confidentiality regarding any information discussed in the group. She will then ask each participant to verbally agree to keep anything discussed in the room confidential, and will remind them at the end of the session not to discuss any group content (including the names of the group participants) outside the focus group.

Only the researcher will have access to the data collected.

\section{POTENTIAL BENEFITS}

There will be no direct benefits to the participant.

\section{COMPENSATION}

There will be no compensation for participating in this study.

\section{CONFIDENTIALITY}

The research data will be kept securely on the researcher's laptop, which is password protected and stored at the researcher's home. All audiotaped interviews and transcripts of those interviews will be erased or destroyed at the end of the study. 


\section{PARTICIPANTS RIGHTS}

Your participation in this study is completely voluntary.

You can refuse to participate in the entire study or any part of the study without any negative effect upon your relationship with San Jose State University or Orchard Elementary and The Center for the Arts. You also have the right to refuse to answer any question posed by the researcher. This consent form is not a contract. It is a written explanation of what will transpire during the study, should you decide to participate. You will not waive any rights if you choose not to participate, and there is no penalty for refusing to participate or for stopping your participation at any point in the study.

QUESTIONS OR PROBLEMS

You are encouraged to ask questions at any time during this study.

- For further information about the study, please contact:

Marie-Helene Bauguil, mhbauguil@mac.com, $408-857-5162$

- Complaints about the research may be presented to Dr. Arnold Danzig, Director of the Ed.D. Program in Educational Leadership at San Jose State University, Arnold.danzig@sjsu.edu

- For questions about participants' rights or if you feel you have been harmed in any way by your participation in this study, please contact Dr. Pamela Stacks, Associate Vice President of the Office of Research, San Jose State University, at $408-924-2479$. 


\title{
Sustaining Arts Education Partnerships in California Elementary Schools
}

\author{
Principal Investigator: Marie-Helene Bauguil
}

\section{SIGNATURES}

Your signature indicates that you voluntarily agree to be a part of the study, that the details of the study have been explained to you, that you have been given time to read this document, and that your questions have been answered. You will receive a copy of this consent form for your records.

\section{Participant Signature}

Participant's Name (printed) Participant's Signature

Date

\section{Researcher Statement}

I certify that the participant has been given adequate time to learn about the study and ask questions. It is my opinion that the participant understands his/her rights and the purpose, risks, benefits, and procedures of the research and has voluntarily agreed to participate.

Signature of Person Obtaining Informed Consent

Date 
Appendix B

\section{Individual Interview Protocol}

\section{General questions}

To principals:

- How long have you been an educator? An administrator?

- Have you had other experiences with arts partnerships in your career?

- How did the partnership with [arts organization name] partnership start? For how long has this partnership continued?

- What art discipline(s) are involved?

- How is the partnership funded?

- What role do you see art playing in education broadly?

- Do you think that sufficient resources are given to the arts in today's schools?

- What role if any, does art have in your life?

To arts organization directors:

- How long have you been an educator? An administrator?

- Have you had other experiences with arts partnerships in your career?

- How did the partnership with [school name] start? For how long has this partnership continued?

- What art discipline(s) are involved?

- How is the partnership funded?

- What role do you see art playing in education broadly?

- Do you think that sufficient resources are given to the arts in today's schools?

To classroom teachers

- How long have you been an educator? At this school?

- Have you had other experiences with arts partnerships in your career?

- What role do you see art playing in education broadly?

- Do you think that sufficient resources are given to the arts in today's schools?

- Have you had any formal training in the arts?

- What role if any, does art have in your life?

To teaching artist:

- What is/are your art discipline(s)?

- How long have you been a teaching artist?

- Have you had other experiences with arts partnerships in your career?

- What role do you see art playing in education broadly? 


\section{Organizational questions}

To principals:

- Would you please describe how the partnership with [arts organization name] works?

- How would you describe your role in implementing the partnership?

- From your perspective, what are the responsibilities of the teaching artist?

- From your perspective, what are the responsibilities of the classroom teachers?

- From your perspective, what are the responsibilities of the arts organization programs director?

To arts organization directors:

- Would you please describe how the partnership with [school name] works?

- From your perspective, what are the responsibilities of the teaching artist?

- From your perspective, what are the responsibilities of the classroom teachers?

- From your perspective, what are the responsibilities of the school principal?

To classroom teachers:

- How does the partnership work?

- How does the collaboration between the teaching artist and yourself work?

To teaching artists:

- How does the partnership work?

- How does the collaboration between the classroom teacher(s) and yourself work?

\section{Curriculum questions}

To principals:

- How would you describe the role of the arts in the general curriculum at your school?

- What is the nature of the curricula that is developed through the partnership?

- Are these curricula related to Common Core goals, and if so, in what ways?

- How do the arts in this schools and the Common Core align? How are they at odds? Do you have any other thoughts on Common Core and the arts?

To arts organization directors:

- How do you develop curriculum?

- Do you follow the California State Standards? 
To classroom teachers:

- Do you teach art disciplines in your classroom? Can you describe an art activity you have done with your class?

- What is the nature of the curricula that is developed through the partnership?

- Are these curricula related to Common Core goals, and if so, in what ways?

- How do the arts in this school and the Common Core align? How are they at odds? Do you have any other thoughts on Common Core and the arts?

- How has integrating the arts influenced your understanding of student learning?

To teaching artists:

- How do you design your lessons?

- Are you familiar with the California State Standards?

- Have you had any training in classroom management?

- Have you had any training in arts integration?

- What additional training, if any, do you need to improve your practice in the classroom?

\section{Challenges/Strategies Questions}

To principals:

- Are there challenges to making this partnership successful? Would you please describe them?

- Have these challenges been resolved?

- If they are resolved, how? If not, are there further actions you can take to resolve them?

- Do you anticipate future challenges?

- Do you see this program continuing indefinitely? How do you see this program in five, 10 years?

- What change would you make to this program?

To arts organization directors:

- What issues do you face when starting a partnership with a school?

- How quickly are these issues resolved, if at all?

- If they are resolved, how? If not, are there further actions you can take to resolve them?

- Do you anticipate future challenges?

- Do you see this program continuing indefinitely? How do you see this program in five, 10 years?

- How do you recruit teaching artists?

- Are there other challenges within your organization that make maintaining the partnership difficult? 
To classroom teachers:

- Are there challenges to making this partnership successful? Could you describe them?

- Are these challenges resolved, if at all?

- If they are resolved, how? If not, are there further actions you can take to resolve them?

- Do you see this program continuing indefinitely? How do you see this program in five, 10 years?

- In your opinion, how could the partnership be improved?

To teaching artists:

- In your opinion, what is the role of the classroom teacher when you are in class?

- What challenges do you face when you enter the classroom for the first time?

- Are these challenges resolved after a few sessions? If yes, how?

- Are there other challenges to making this partnership successful? Would you describe them?

- Are these challenges resolved, if at all? If they are resolved, how? If not, are there further actions you can take to resolve them?

- In your opinion, how could the partnership be improved?

\section{Benefits Questions}

To school principals:

- What impact does this partnership has on students?

- What impact does this partnership has on teachers?

- What impact does this partnership have on yourself?

- Please describe the benefits of this partnership.

To arts organization directors:

- What does the partnership with [school name] bring to you? To your organization?

To classroom teachers:

- What does the partnership with [art organization] bring to your classroom? To you? To your students?

To teaching artists:

- What do you like the best about the partnership?

- What do you like best about your work in the classroom? 


\section{School Culture Questions}

To principals:

- In your opinion, how do the teachers perceive the role of teaching artists?

- In your opinion, have the teachers' attitudes toward arts education changed since the partnership began? If so, in what ways?

Classroom teachers:

- How does your school leadership support the arts?

- What place do the arts have in your classroom?

- How has integrating the arts influenced your view of collaboration?

- How has integrating the arts influenced the learning environment in your classroom?

- In your opinion, how important are the arts in education?

To teaching artists:

- Do you feel welcome and appreciated in the classroom? In the school?

- In your opinion, how important are the arts in education?

- How has integrating the arts influenced the learning environment in your classroom? 


\section{Appendix C \\ Group Interview Protocol}

\section{Questions}

- How does the partnership work?

○ How do you see your role and your responsibility in the partnership?

○ How is curriculum designed and developed?

- How do arts in this school and the Common Core goals align? How are they at odds? Do you have any other thoughts on Common Core goals and the arts?

- How does the residency change your daily routine?

- Have there been/are there challenges to make this partnership successful? Could you describe them? How do you address these?

- Please describe the benefits of this partnership. What benefits does the partnership bring to you? To your students? To the school?

- How has integrating the arts influenced your view of collaboration?

- Has the partnership changed your view of student learning?

- Has the partnership changed your teaching practice?

- What change would you make to this program?

- More generally, how do you view the role of the arts in education? 
Appendix D

Observation Protocol

\begin{tabular}{|l|l|}
\hline Teacher observed: & Date: \\
\hline School: & Time: \\
\hline
\end{tabular}

What does the teaching artist do?

What does the classroom teacher do?

What characterizes the interactions between the classroom teacher and the teaching artist: Trust?

Clear communication?

Support and assistance?

Something else?

How engaged are students in the activity?

Map of the room 


\section{Orchard - Center for the Arts Residency ( ${ }^{\text {nd }}$ Gr.) Integrated learning/Storytelling and movement}

Timeline:

\section{October 5, 2016, 12:10-12:50 \\ Residency planning meeting}

Murphy, the Center for the Arts Director of Education, introduces me to the teacher and the teaching artist (TA) at a mid-residency planning meeting. I introduce myself (what I do, the subject of my doctorate, my plan for the study). I stay for the rest of the meeting. I feel welcome.

The TA (Jim) and the four $2^{\text {nd }} \mathrm{Gr}$ teachers are present (Deanna, Jessie, Jacky, Maggie); two teachers arrive late (Deanna and Jessie). Principal attends half of the meeting. She seems very supportive of the program.

Meeting takes place in Maggie's classroom, during teachers' lunch break. Teachers eat their lunches during the meeting.

Teachers discuss the two previous residency sessions, which they led without the TA being present. They discuss their experiences; some activities worked, others did not. The teachers comment on the students with special needs, who could not attend due to their placement in special classes at the time of Jim's lesson. According to the teachers, these students are those that need the residency class the most.

TA offers feedback on teacher-led activities. He is very confident and articulate when he speaks; he has a voice that carries, a "theater voice." Jim is passionate; strongly believes in what he does with the children. He gives a long explanation of the distinction between integrated learning and interdisciplinary learning. I am under the impression it is for my benefit.

Discussion is not easy to follow when it becomes very specific regarding the content of the activities, since I am not familiar with them at all (I do not know what "shape" and "tableau" mean in this context). I listen and write down questions and comments I plan to follow up on during subsequent observations and interviews.

Teachers and TAs plan the content of the next two sessions, which will be led entirely by the TA.

The next planning meeting is scheduled for Oct 19, which I may not attend (waiting for IRB approval) 
Murphy cc'd me in the recap e-mail of the 10/5/17 meeting she sends to the teachers and the TA.

IRB approval arrives on November 8; there is only one residency session left (November 16/17)

I arrange a one-on-one interview via e-mail with one of the teachers (Jacky) for the same day, during lunchtime.

\section{November 16, 2016, 7:50-1:00 \\ Observations and teacher interview}

Last day of teaching artist residency

TA's sessions are back-to-back, 50-minutes long, fire drill during the second session.

I speak briefly with Jacky as she gets her students ready to leave the room, about where to meet for the interview at the end of her class. Jim overhears our conversation and suggests that we all meet for a wrap-up of the session. In the few minutes we wait for the next class to arrive, he tells me that Jacky and Jessie chose words that were too difficult to express in a "shape." That bothers him; he is eager to discuss this with the teachers and give his feedback before he leaves the school, as today is his last day.

Murphy, Center for the Arts Director of Education attends most of the last class period.

When the last session is completed, Director of Ed. (Murphy), the TA and I walk together toward the office. The TA discusses with Director of Ed. the choice of words teachers used for the activity they led. He repeats what he told me earlier, that the two of the teachers used words too difficult and too abstract to be acted out. He asks for my opinion. We stop at Maggie's classroom. Director of Ed. states she would like to stay for the meeting but cannot.

Debrief meeting, during lunchtime (10 minutes)

In Maggie's classroom, while teachers are having their lunch. (Do all planning meetings happen here? Her classroom's location is central to the campus, close to the office building).

Participants: Deanna, Jacky, Maggie, and Jim. Principal stops by for a few minutes.

Teachers discuss their experiences with leading the morning tableau/shape activities. TA gives feedback on the choice of words the teachers used (either Language Arts vocabulary revision, or vocabulary from science plant unit the student are learning at the moment). Some words were good examples for tableaux and shapes, such as "cocoon," while other were not good choices, as they were too abstract to "act" (ex: brim, boasted). 
Teachers are very comfortable with each other and with the teaching artist. They debate the pros and cons of the choice of words. Jacky and Deanna smile and laugh while recounting their experiences with leading the shape/tableau activity. Jacky recounts a problem she had with a student, and the fact that she had to ask Jim to call the office, since she was busy with the rest of the students I feel there is a strong sense of camaraderie, friendliness and trust among these people.

Although I feel welcome at this spontaneous meeting, I do not audiotape it and did not ask to do so.

My scheduled individual interview turns into a group interview, which begins right after the debrief.

Same participants: Jacky, Deanna, Maggie (teachers) and Jim (teaching artist)

\section{Residency classroom description:}

Multi-usage room, no desks, large, wide space.

The room feels welcoming, warm (is it because Jim is walking bare foot and playing his concertina when I enter the room?), even though it does not feel very neat (lots of miscellaneous furniture and materials are laid out along the walls).

\section{Recap Data Collection for Orchard}

\section{Classroom Observations}

- Four $2^{\text {nd }}$ grade classrooms (notes for each classroom below)

- Teacher-TA debrief meeting

\section{Interviews:}

- Group interview:

○ 30 minutes (same day as observations, during teachers' lunch time)

○ Participants: Jim (TA), Deanna, Jacky, Maggie (teachers)

- Individual Interview:

○ TA/Jim: 50 minutes.

○ Date: December $5^{\text {th }}$, three weeks after my observation

o Jim offers to choose a cafe near my work 


\section{Other documents:}

Center for the Arts Director of Education shares with me:

- The complete correspondence (e-mails) between the TA and the teachers during the residency. In one of the e-mails, the TA asks Murphy about my study. "I have not heard from the researcher at all, and today would have been a day to observe."

- Feedback document from the teachers regarding their experiences with the previous residencies with the TA (this is the $4^{\text {th }}$ year) and how they plan to incorporate some of the TA's activities into the general curriculum.

As I read the chain of e-mails, I realize that most of the lesson planning is done in these e-mails. According to the Director of Education, the residency includes three formal meetings, one before the residency begins, and two during the residency. According to the e-mails, the pre-residency planning meeting did not happen in person, rather, teachers and TAs communicated and planned the first lesson through e-mails. As for the two midresidency meetings, there was no set time in the teachers' schedules for these meetings, so they occurred during the teachers' lunchtime.

\begin{tabular}{|l|l|}
\hline Teacher: Deanna & Date: Nov 16 \\
\hline TA: Jim & Time: $8: 20-9: 10$
\end{tabular}

Principal visits the class, stays for about 15 minutes

She remembers my name from when I met her in the office after signing up. What does the TA do?

Before class starts:

Waiting for students, playing his concertina, not wearing shoes.

Directs students to remove their shoes, sit in a circle, reminds them about the warm-up routine; he speaks to them using their nametags.

While he leads the warm up (yoga poses, stretching exercises), he also explains to me the purpose of the routine (making students aware of their bodies).

Assist teacher with the acting of "tableaux" or "shapes."

"A shape is any position you put your body in. What is a tableau? It's something that we use in theater sometimes. It's a photograph of a scene of not only the people in the scene, but the objects that are important. A tableau is a frozen moment of a story where bodies are representational of things in that scene" (from TA interview).

Remind students about space in theater (back stage, side stage, audience), and stage routines (take two minutes to get ready, facing the audience when acting the words).

Finish session by asking students to reflect on what they did during the session. What did they learn? What did they learn to do better? 


\section{What does the classroom teacher do?}

Keeps her boots on. Joins the circle. Does some of the warm ups.

Leads the activity (students in group of four create a shape that represent a vocabulary word from the unit on plants and animals they are studying in class [word examples: casting, arachnid]).

Shows confidence, calm, enjoyment in the activity she leads.

What characterizes the interactions between the classroom teacher and the teaching artist:

Trust?

Yes

Clear communication?

Yes

Yes

Clear communication?

Support and assistance?

The teacher and the TA are very comfortable with one another

Something else?

How engaged are the students in the activity?

Interested, attentive, enjoying the activities.

Participate in the group discussion at the end of the class.

\begin{tabular}{|l|l|}
\hline Teacher: Jessie & Date: Nov 16 \\
\hline TA: Jim & Time: 9:10-10:00 \\
\hline
\end{tabular}

Fire drill, cut 20 minutes of the session

What does the teaching artist do?

Same routine as previous class.

Sits on the side of the room, observes students and teacher leading the "shape" activity.

Support teacher; give additional instructions to students from time to time.

\section{What does the classroom teacher do?}

Seems to have a lot on her mind, stressed.

Does not participate in the warm up. Writes down a list of words (painful, aggressive, deadly, precise, rushed, roared, fierce, huddle, waddle, jackrabbit, roam) on the board to help the audience to guess the words that are acted.

What characterizes the interactions between the classroom teacher and the teaching artist:

Trust? Yes

Support and assistance? Yes

Something else?

How engaged are the students in the activity?

They enjoy the class. Several boys are acting out (special needs?). 


\begin{tabular}{|c|c|}
\hline Teacher: Jacky & Date: Nov 16 \\
\hline TA: Jim & Time: $10: 20$ \\
\hline \multicolumn{2}{|c|}{ What does the teaching artist do? } \\
\hline \multicolumn{2}{|c|}{$\begin{array}{l}\text { Same routine as previous class } \\
\text { Remind students of "ocean breathing" (deep breathing) }\end{array}$} \\
\hline \multicolumn{2}{|c|}{ Places himself next to wall and observes the teacher leading a shape activity } \\
\hline \multicolumn{2}{|c|}{$\begin{array}{l}\text { Leads "sneaky statues" activity at the end of class. (TA faces the wall and tells a story, } \\
\text { students move around the room. When the TA stops and turn toward the students, they } \\
\text { must be in groups of two or three and frozen in a pose). }\end{array}$} \\
\hline \multicolumn{2}{|c|}{$\begin{array}{l}\text { Plays concertina and releases students one at a time (students lay on the floor, TA } \\
\text { releases them by touching them one after the other with one foot). }\end{array}$} \\
\hline \multicolumn{2}{|c|}{ What does the classroom teacher do? } \\
\hline \multicolumn{2}{|c|}{$\begin{array}{l}\text { She is confident, poised, calm, smiles; enjoys the class } \\
\text { Participates in the warm ups. } \\
\text { Leads the class activity (individual activity this time) } \\
\text { Students stand apart from each other, are given a word they must act. She repeats the } \\
\text { word several times and gives a count of five. } \\
\text { She tell students to be in their "imaginary space" while they act the word. }\end{array}$} \\
\hline \multicolumn{2}{|c|}{ What characterizes the interactions between the classroom teacher and the teaching artist: } \\
\hline $\begin{array}{l}\text { Trust? Yes } \\
\text { Clear communic } \\
\text { Support and ass } \\
\text { Something else? }\end{array}$ & very comfortable with one another. \\
\hline \multicolumn{2}{|c|}{ How engaged are the students in the activity? } \\
\hline $\begin{array}{l}\text { Very engaged, } \\
\text { Many students } 1 \\
\text { the year. [ex: "b }\end{array}$ & $\begin{array}{l}\text { ocabulary words are from beginning of } \\
\text { d," "greedy," "strolled," "determined"]). }\end{array}$ \\
\hline
\end{tabular}




\begin{tabular}{|c|c|}
\hline Teacher: Maggie & Date: Nov 16 \\
\hline TA: Jim & Time: 11:10-12:00 \\
\hline \multicolumn{2}{|l|}{ What does the teaching artist do? } \\
\hline \multicolumn{2}{|l|}{ Leads warm up } \\
\hline \multicolumn{2}{|c|}{ Sits on the side while the teacher leads the activity } \\
\hline \multicolumn{2}{|c|}{ Releases students at the end of class (see description of activity above). } \\
\hline \multicolumn{2}{|c|}{ What does the classroom teacher do? } \\
\hline \multirow{3}{*}{\multicolumn{2}{|c|}{$\begin{array}{l}\text { She sits outside the circle during the warm-up exercises and does not participate. She } \\
\text { seems preoccupied or deep in thought, tense } \\
\text { Leads the class activity. Organizes the students in groups of four and gives each group a } \\
\text { word or group of words from two readings about the plant and animal unit they are } \\
\text { studying in class. } \\
\text { She smiles at the end of class and seems more at ease (was she feeling insecure about } \\
\text { leading this activity?) }\end{array}$}} \\
\hline & \\
\hline & \\
\hline \multicolumn{2}{|c|}{ What characterizes the interactions between the classroom teacher and the teaching artist: } \\
\hline \multicolumn{2}{|l|}{ Trust? Yes } \\
\hline \multicolumn{2}{|l|}{ Clear communication? Yes } \\
\hline \multicolumn{2}{|l|}{ Support and assistance? Yes } \\
\hline \multicolumn{2}{|l|}{ Something else? } \\
\hline \multicolumn{2}{|c|}{ How engaged are the students in the activity? } \\
\hline Focused, enjoying the activities & \\
\hline
\end{tabular}




\section{Appendix F \\ Final Coding}

Context description

CftA Residency Model

From the schools

From the arts organizations

Valley Arts Studio

Teaching VAPA standards

Opera assembly

Selecting arts programs

Appreciation for the arts partnerships

Beliefs

Beliefs about arts education

Beliefs about the school system (TA/AO staff)

Low priority

Benefits (RQ 1A)

Impact on teachers

Impact on children

Grow confidence

Deepen understanding

Connect to real life

Teach a process

Challenges (RQ 1B)

Burden for teaching artists

Managing classrooms

Feeling isolated

Getting feedback from teachers

Meeting with other teaching artists

Designing curriculum

Lack of training in child development

Short residencies

Burden for teachers

Fast pace of lessons

Finishing arts projects

Finding collaboration time

Program consistency

Continuity with curriculum 
Scheduling

Changing daily routine (teachers)

Back-to-back classes (visual artists)

Teacher participation

Hiring visual artists (arts organizations)

Strategies (RQ 1C)

Training teachers

Providing lesson plans

Shadowing classroom teachers

Engaging teachers with the arts

Hiring artists

Building relationships

Funding

Funding Materials

Developing integrated curriculum

Collaborating 